\author{
UNIVERSIDADE DE SÃO PAULO \\ INSTITUTO DE ENERGIA E AMBIENTE \\ PROGRAMA DE PÓS-GRADUAÇÃO EM CIÊNCIA AMBIENTAL
}

RAFAEL DE ARAUJO AROSA MONTEIRO

O DIÁLOGO EM PROCESSOS DE EDUCAÇÃO AMBIENTAL: ANÁLISE DAS RELAÇÕES EXISTENTES ENTRE UMA ONG E PESCADORES ARTESANAIS MARÍTIMOS DO LITORAL PAULISTA. 
RAFAEL DE ARAUJO AROSA MONTEIRO

\section{O DIÁLOGO EM PROCESSOS DE EDUCAÇÃO AMBIENTAL: ANÁLISE DAS RELAÇÕES EXISTENTES ENTRE UMA ONG E PESCADORES ARTESANAIS MARÍTIMOS DO LITORAL PAULISTA.}

Dissertação apresentada ao Programa de PósGraduação em Ciência Ambiental do Instituto de Energia e Ambiente da Universidade de São Paulo para a obtenção do título de Mestre em Ciência Ambiental.

Orientador: Prof. Dr. Marcos Sorrentino

Versão Revisada

SÃO PAULO

2018 
AUTORIZO A REPRODUÇÃO E DIVULGAÇÃO TOTAL OU PARCIAL DESTE TRABALHO, POR QUALQUER MEIO CONVENCIONAL OU ELETRÔNICO, PARA FINS DE ESTUDO E PESQUISA, DESDE QUE CITADA A FONTE.

FICHA CATALOGRÁFICA

Monteiro, Rafael de Araujo Arosa.

O diálogo em processos de educação ambiental: análise das relações existentes entre uma ONG e pescadores artesanais marítimos do litoral paulista. / Rafael de Araujo Arosa; orientador: Marcos Sorrentino. - São Paulo, 2018.

131f.: il; $30 \mathrm{~cm}$.

Dissertação (Mestrado em Ciência Ambiental) - Programa de PósGraduação em Ciência Ambiental - Instituto de Energia e Ambiente da Universidade de São Paulo.

1. Educação ambiental. 2. Pesca artesanal. 3. Organização não governamental - ONG. I. Título. 
Nome: MONTEIRO, Rafael de Araujo Arosa

Título: O diálogo em processos de educação ambiental: análise das relações existentes entre uma ONG e pescadores artesanais marítimos do litoral paulista.

Dissertação apresentada ao Programa de Pós-

Graduação em Ciência Ambiental do Instituto de Energia e Ambiente da Universidade de São Paulo para a obtenção do título de Mestre em Ciência Ambiental.

Aprovado em:

Banca Examinadora

Prof. Dr. Instituição:

Julgamento: Assinatura:

Prof. Dr. Instituição:

Julgamento: Assinatura:

Prof. Dr. Instituição:

Julgamento: Assinatura:

Prof. Dr. Instituição:

Julgamento: Assinatura: 


\section{DEDICATÓRIA}

A meus pais, Celso Arosa Monteiro Filho e Maria Luzia de Araujo Arosa Monteiro, e a minha irmã, Marina de Araujo Arosa Monteiro. 


\section{AGRADECIMENTOS}

Muitas foram as pessoas que contribuíram para a concretização desse momento de vida em que me encontro. Agradecer a cada uma nominalmente seria uma tarefa difícil para a memória, lembrando de cada gesto, de cada palavra e de cada incentivo. Por isso, emano aqui um sentimento de agradecimento à todas e todos que cruzaram meu caminho.

No entanto, há aquelas(es) que não posso deixar de agradecer nominalmente. Em

primeiro lugar quero agradecer à essa energia/entidade/Ser Maior, ou qualquer outra denominação que se escolha dar, a que eu opto por chamar de Deus, pela oportunidade de estar vivo e de trilhar essa jornada pela vida.

Quero agradecer a minha família, meu pai, minha mãe e minha irmã por todo o apoio que me deram e me dão. Palavras não são suficientes para descrever o sentimento de acolhimento, segurança e gratidão por tudo que fazem por mim.

Ao meu orientador, prof. Dr. Marcos Sorrentino, a oportunidade de iniciar a caminhada pela ciência e por todos as conversas que tanto contribuíram para o meu amadurecimento intelectual, vivendo as delícias e os desafios desse processo.

Aos meus colegas do Laboratório de Educação e Política Ambiental - Oca pelos aprendizados tecidos, pelas vivências e pelo acolhimento afetivo e físico, tão importantes para a concretização desta pesquisa.

Aos meus colegas de trabalho que tive durante o período em que trabalhei no Instituto Biopesca e à própria instituição pela oportunidade que me auxiliou a perceber a Educação Ambiental enquanto um caminho profissional instigante e acolhedor.

Aos pescadores pelas conversas, pelos encontros e pelos valiosos aprendizados que muito contribuíram para a minha formação enquanto educador ambiental, auxiliando-me a perceber os desafios que enfrentam e como a Educação Ambiental pode contribuir para a superação dos mesmos.

A todos que colaboraram comigo na realização do trabalho de campo desta pesquisa, cedendo entrevistas.

À banca de qualificação deste trabalho, Prof. Dr. Daniel Andrade e Prof. Dr. Pedro Jacobi, pelas importante considerações e provocações que auxiliaram o amadurecimento desta pesquisa. 
Ao Programa de Pós-Graduação em Ciência Ambiental e toda a equipe que dele faz parte, em especial à equipe da secretaria que muito me auxiliou durante o processo. 


\section{RESUMO}

MONTEIRO, Rafael de Araujo Arosa. O diálogo em processos de educação ambiental: análise das relações existentes entre uma ONG e pescadores artesanais marítimos do litoral paulista. 2018. 131 f. Dissertação (Mestrado em Ciência Ambiental) - Instituto de Energia e Ambiente, Universidade de São Paulo, São Paulo, 2018.

Esta pesquisa buscou contribuir para o aprofundamento da compreensão do diálogo em processos de educação ambiental (EA) e da formulação de indicadores que permitam averiguar a dialogicidade no fazer das/dos educadoras(es) ambientais, uma vez que se constitui enquanto um princípio-base a ser adotado em processos educadores que sejam de fato transformadores da realidade. Para isso, buscou-se analisar como se deu o processo educador desenvolvido por uma organização não governamental com pescadores artesanais marítimos do litoral paulista, respondendo a seguinte pergunta de pesquisa: As atividades de EA e de pesquisa desenvolvidas por uma ONG com pescadores artesanais marítimos do litoral paulista contribuíram para fomentar o diálogo entre a ONG e os pescadores em busca de uma transição para a pesca responsável e da melhoria das condições existenciais dos pescadores? Os dados foram coletados por meio da análise de documentos e de entrevistas semiestruturadas, sendo analisados a partir de uma síntese das ideias de Martin Buber, David Bohm, William Isaacs e Paulo Freire sobre o diálogo, composta por um conjunto de perguntas-indicadoras divididas em três categorias: aspectos externos, aspectos internos e ação dialógica. Os resultados encontrados demonstram a incipiência do diálogo na relação entre os atores. Os aspectos externos dialógicos se limitaram à frequência semanal das conversas e a algumas formas de disposição dos participantes em determinados encontros. Os aspectos internos revelaram o estabelecimento de dois tipos de relação: uma antidialógica e outra que chamei de dialógica incipiente por apresentar alguns indícios de emergência do diálogo, não sendo, no entanto, fortes o suficiente para caracterizar a existência de um campo relacional dialógico. Em relação à ação dialógica foi possível verificar o início de um processo de acordo com os princípios dos círculos de cultura. No entanto, a falta de priorização da continuidade de tal processo nos permite afirmar que não houve uma ação dialógica de acordo com os indicadores elaborados, caracterizando-se, assim, enquanto uma emergência dialógica suprimida. Além disso, quanto às estratégias pedagógicas adotadas nos diferentes encontros de EA é possível afirmar que aquela utilizada nos diagnósticos participativos foi a única que potencializou a emergência do diálogo. Por fim, vale destacar as potencialidades dialógicas encontradas nos dois atores da pesquisa. Alguns pescadores 
apresentaram uma forte postura de abertura ao Outro, inclusive se permitindo enfrentar e superar medos adquiridos em outras relações, realizando, assim, a suspensão de tais pressupostos. A ONG, por sua vez, apresentou importantes atitudes estimuladoras do diálogo, como a escuta genuína, o respeito, a não utilização de linguajar acadêmico e a não imposição de ideias. Todas essas potencialidades devem ser estimuladas juntamente com a criação de novas, de forma a permitir o avanço na existência dialógica e a efetividade da transição para um novo modelo de pesca e de sociedade.

Palavras-chave: Diálogo. Educação Ambiental. Indicadores de diálogo. Organização Não Governamental. Pescadores Artesanais. 


\begin{abstract}
MONTEIRO, Rafael de Araujo Arosa. The dialogue in processes of environmental education: analysis of the existing relationships between an NGO and artisanal maritime fishermen on the coast of São Paulo. 2018. 131 p. Dissertation (Master in Environmental Science) Institute of Energy and Environment, Universidade de São Paulo, São Paulo, 2018.
\end{abstract}

This research sought to contribute to the deepening of the understanding of the dialogue in environmental education (EE) processes and the formulation of indicators that allow to ascertain the dialogicity in the making of the environmental educators, since it constitutes as a base principle to be adopted in educative processes that are in fact transforming reality. To this, we sought to analyze how the educator process developed by a non-governmental organization with maritime artisanal fishermen from the coast of São Paulo answered the following research question: The EE and research activities developed by an NGO with artisanal marine fishermen coast of the state helped to foster dialogue between the NGO and the fishermen in search of a transition to responsible fishing and improvement of the existential conditions of fishermen? The data were collected through the analysis of documents and semi-structured interviews, being analyzed from a synthesis of the ideas of Martin Buber, David Bohm, William Isaacs and Paulo Freire on the dialogue, composed of a set of questions-indicators divided into three categories: external aspects, internal aspects and dialogical action. The results show the incipience of dialogue in the relationship between the actors. The external dialogical aspects were limited to the weekly frequency of the conversations and to some forms of disposition of the participants in certain meetings. The internal aspects revealed the establishment of two types of relation: one anti-dialogical and another that I called incipient dialogic for presenting some signs of emergence of the dialog, not being, however, strong enough to characterize the existence of a dialogical conversational field. In relation to the dialogical action it was possible to verify the beginning of a process according to the principles of the culture circles. However, the lack of prioritization of the continuity of such a process allows us to affirm that there was no dialogical action according to the elaborated indicators, thus characterizing itself as a suppressed dialogical emergency. In addition, regarding the pedagogical strategies adopted in the different EE meetings, it is possible to affirm that the one used in the participatory diagnoses was the only one that potentiates the emergence of the dialogue. Finally, it is worth highlighting the dialogical potentialities found in the two actors of the research. Some fishermen presented a strong attitude of openness to the Other, including allowing themselves to face and overcome fears 
acquired in other relationships, thus making the suspension of such assumptions. The NGO, on the other hand, presented important stimulating attitudes of dialogue, such as genuine listening, respect, non-use of academic language and non-imposition of ideas. All these potentialities must be stimulated together with the creation of new ones, in order to allow the advancement in the dialogical existence and the effectiveness of the transition to a new model of fishing and society.

Keywords: Dialogue. Environmental Education. Dialogue indicators. Non-Governmental Organization. Artisanal Fishermen. 


\section{SUMÁRIO}

i. APRESENTAÇÃO DO AUTOR E DOS OBJETIVOS DA PESQUISA ......................................13

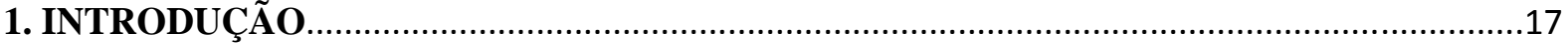

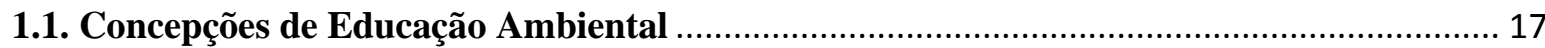

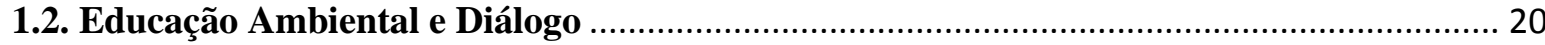

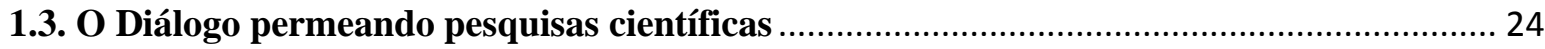

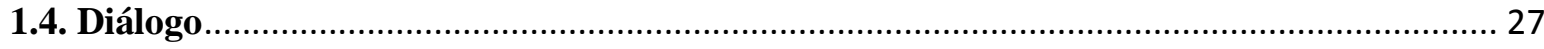

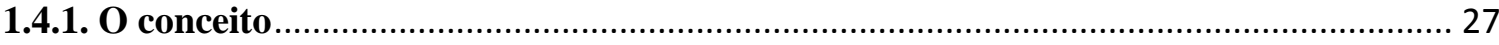

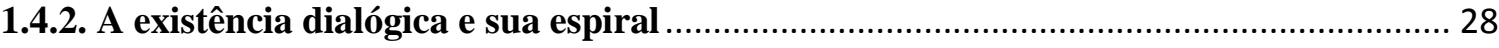

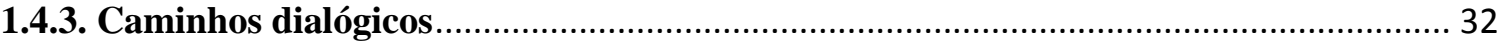

1.4.4. Síntese dos caminhos metodológicos e perguntas-indicadoras......................................... 45

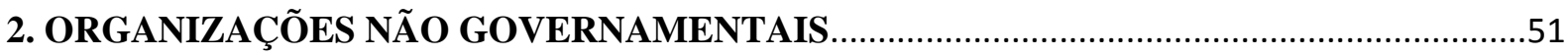

2.1. Definição

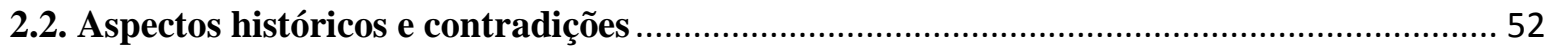

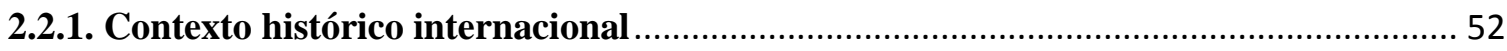

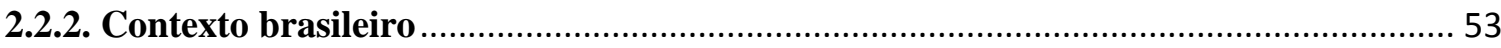

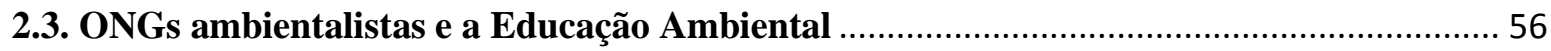

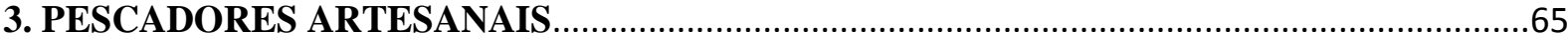

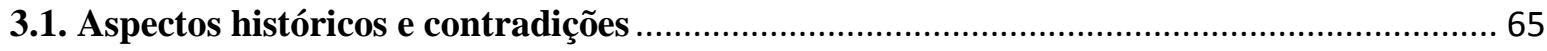

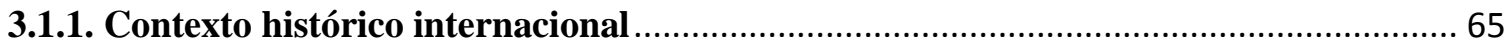

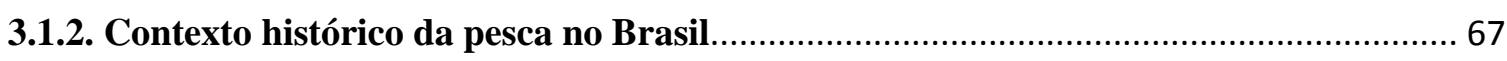

3.2. Código de Conduta para a Pesca Responsável ............................................................... 70

3.3. Educação ambiental e pescadores artesanais ….......................................................... 73

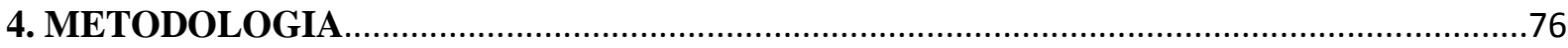

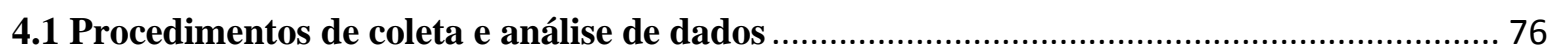

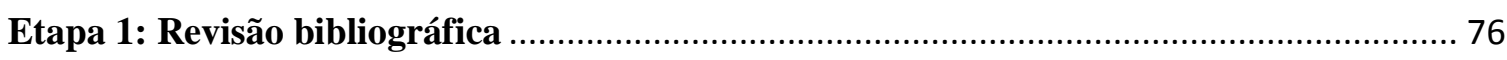

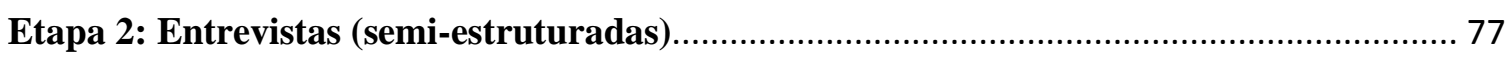

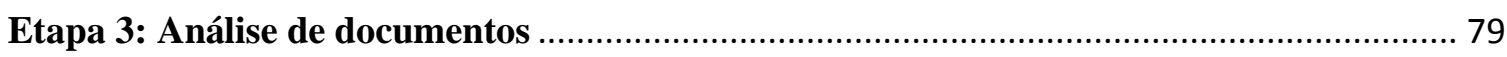

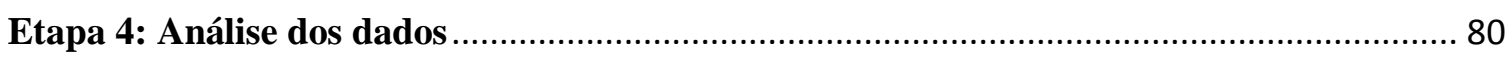

Etapa 5: Devolutiva para os participantes da pesquisa .................................................. 80

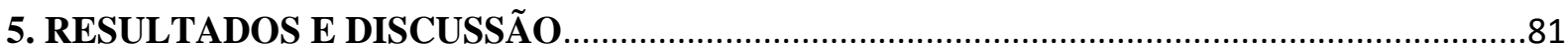

5.1 Caracterização do processo educador promovido pelo Instituto Biopesca ......................... 81

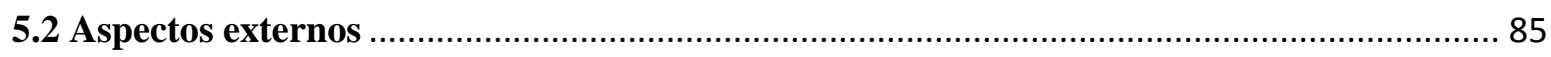

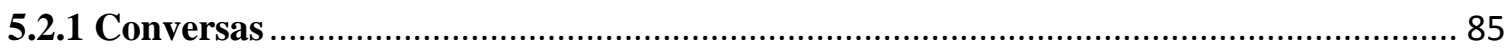

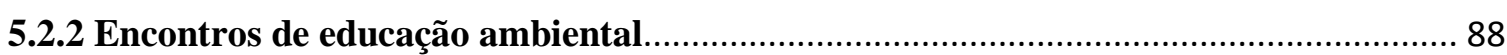


5.2.3 Considerações sobre os aspectos externos 92

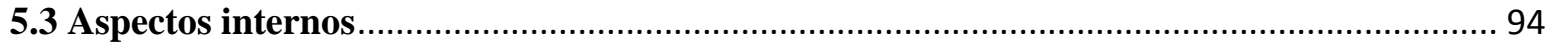

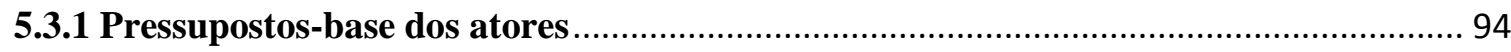

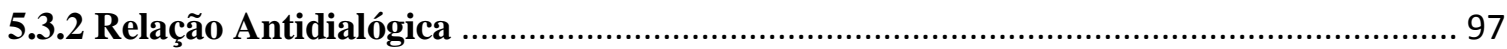

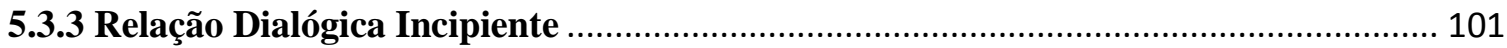

5.3.4 Considerações sobre os aspectos internos ............................................................... 105

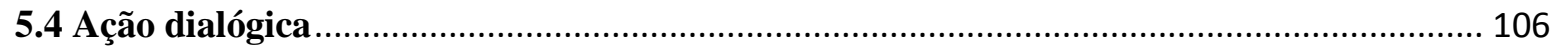

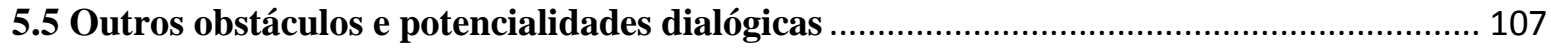

5.6 Considerações sobre o campo relacional estabelecido na relação entre os atores e suas

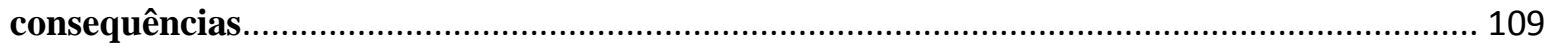

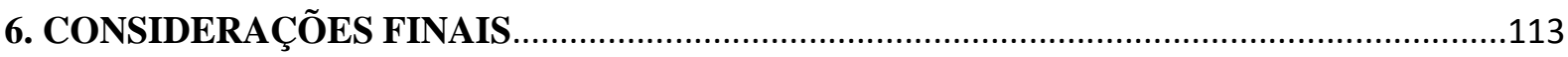

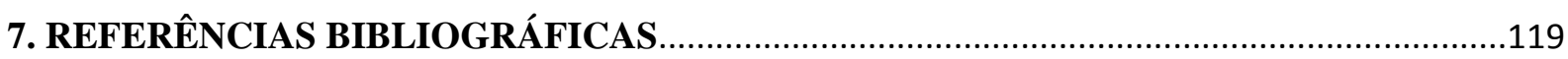




\section{i. APRESENTAÇÃO DO AUTOR E DOS OBJETIVOS DA PESQUISA}

Ao longo da minha graduação (2008 - 2012) no curso de Gestão Ambiental da Escola de Artes, Ciências e Humanidades (EACH) da Universidade de São Paulo tive a oportunidade de participar de alguns trabalhos de Educação Ambiental (EA). Apesar disso, eu tinha a pretensão de atuar com gerenciamento e gestão de processos dentro de uma empresa, estimulado pelo retorno financeiro que tal trabalho me forneceria.

Logo que me formei fui contratado para trabalhar com gestão ambiental em obras, o que foi uma forte alegria na época. Mas essa emoção logo se dissipou. No breve tempo em que estive nesse contexto pude perceber como a questão ambiental era tratada de forma periférica, com pouca importância, trazendo-me fortes desencantos e frustrações. Reavaliando então meus objetivos profissionais tive a oportunidade de me reaproximar da educação, trabalhando num espaço escolar de reforço para estudantes com algum tipo de dificuldade em sua trajetória escolar. O contato com cada aluno que tive a oportunidade de ensinar e aprender foi fundamental para restabelecer a fé e a esperança dentro de mim sobre a busca por mudanças socioambientais. E por isso sou grato às coordenadoras do espaço escolar e às(aos) estudantes. Depois de oito meses nesse processo de reestruturação e fortalecimento interno surgiu a oportunidade de voltar a atuar com processos de educação ambiental em uma Organização Não Governamental (ONG) de conservação marinha, chamada Instituto Biopesca, com pescadores artesanais. Fiquei muito empolgado com a possibilidade de trabalhar com essas pessoas, de me aproximar de outras formas de ver e viver a vida.

Ao longo do caminhar desse novo momento da minha vida, o qual perdurou por dois

anos, fiz uma pós-graduação lato sensu intitulada "Educação Ambiental para a Sustentabilidade" pelo Senac-SP. Assim, pude aliar teoria e prática, implementando metodologias aprendidas no curso, levando dúvidas sobre as práticas de EA desenvolvidas na ONG aos meus professores e identificando/vivenciando vários dos desafios já consagrados da EA no trabalho que realizava, como a dificuldade de se trabalhar com uma equipe reduzida, possuindo grande demanda de trabalho, os hábitos educacionais de transmissão de conteúdo que adquirimos ao longo de nossos processos educadores e que replicamos naqueles que propomos e por aí vai.

Ao final de 2015, o trabalho na ONG teve seu fim, pois findou o patrocínio. Visando conciliar meu desejo de fazer mestrado, para me tornar professor universitário, e a vontade de tentar dar continuidade, mesmo que reduzida, ao trabalho que vinha sendo desenvolvido pela 
ONG com os pescadores, submeti ao Programa de Pós-Graduação em Ciência Ambiental um projeto de pesquisa-ação. No entanto, ao ingressar no mesmo, muitos aspectos foram mostrando a dificuldade de realizar a proposta feita. As conversas de orientação com o Prof. Dr. Marcos Sorrentino foram muito importantes para o esclarecimento do enorme recorte que deveria ser feito no projeto para que os prazos fossem cumpridos e a dissertação entregue ao final do período vigente do mestrado.

Tal situação se distanciava daquilo que eu almejava quando escrevi o projeto: realizar uma intervenção que acarretasse mudanças profundas na comunidade. E com isso, ficou claro que as possíveis transformações, caso ocorressem, no curto período de tempo do mestrado seriam mais superficiais. Além disso, durante a disciplina Pesquisa Interdisciplinar Ambiental, ministrada pelo Prof. Dr. Pedro Jacobi, Profa. Dra. Silvia Zaniratto e Profa. Dra. Tatiana Rotondaro foi discutida a importância do fator tempo para a realização de uma pesquisa-ação, sendo recomendado fazê-la com prazos mais longos, como no doutorado.

Após o entendimento das limitações do mestrado, muitas conversas se deram entre orientador e orientado com o propósito de encontrar uma nova proposta de pesquisa, uma que considerasse as intervenções já realizadas pela ONG supracitada com os pescadores artesanais ao longo dos dois anos que integrei a equipe, de 2013 a 2015.

Buscando encontrar aspectos a serem analisados nas intervenções, escolhi um entre os cinco conceitos considerados pilares da Educação Ambiental para o Laboratório de Educação e Política Ambiental (Oca) da Escola Superior de Agricultura Luiz de Queiroz (ESALQ/USP), o diálogo. O processo de estudo e aprofundamento deste pilar teve e vem tendo um impacto muito grande na minha vida enquanto ser humano. O entendimento dos princípios dialógicos tem me permitido perceber minhas contradições e meus pressupostos, a partir do exercício de um mergulho interno. Em paralelo, auxilia-me a compreender o Outro, pois consigo identificar neles algumas das minhas próprias contradições.

Muitos foram os momentos em que tive a oportunidade de me relacionar com pessoas e observar, a partir da lente do diálogo, como me relaciono com elas, como elas se relacionam entre si, quais os conflitos que emergem, por que emergem e por aí vai. Ter o diálogo como objeto de pesquisa me permitiu ir desvelando as relações. Isso me oportunizou estabelecer uma conexão constante entre as ideias dos autores que estudei e aquilo que vivia no meu cotidiano. As conversas durante as reuniões do laboratório de Educação e Política Ambiental (Oca), as conversas com minha família, com meus amigos, com desconhecidos, trouxeram diferentes insights para o aprofundamento da compreensão sobre a relação dialógica. 
E entendendo que a nossa forma de nos relacionarmos com o Outro (humano ou não humano), construída historicamente, acarretou diversos problemas ambientais da contemporaneidade (BUBER, 1979; 2014; BOHM, 2005; FREIRE, 1981; 1983; 1992; 2013), a partir de uma forma de relação muito voltada para si próprio (BUBER, 2014), estimulados pelo paradigma fragmentador do pensamento (BOHM, 2005), que nos separa ao invés de unir (FREIRE, 1981), faz-se necessário buscar caminhos para superar tal situação, promovendo a transição para novas relações.

Um desses caminhos possíveis são os processos educadores ambientalistas dialógicos, os quais permitem aos sujeitos desconstruir os aspectos internos da relação degradante supracitada e construir novos, a partir do desvelamento das condições histórico-culturais, possibilitando a transformação do pensamento e, portanto, a transformação da consciência, a qual potencializa ações em busca de mudanças socioambientais na realidade vivida (BOHM, 2005; FREIRE, 1981; SORRENTINO et. al., 2013).

Luca e Andrade (2013) afirmam que o diálogo enquanto objeto de pesquisa é ainda “[...] um fato relativamente recente e remonta, de forma mais intensiva, ao início dos anos de 1980 (YANKELOVICH, 2001) ${ }^{1}$, o que significa que uma teoria operacional está ainda em processo inicial de construção (ISAACS, 1993) ${ }^{2}$ [...]” (p. 126), de forma que um ponto de grande relevância a ser desenvolvido em tal teoria operacional é a elaboração de indicadores que permitam verificar a ocorrência de aspectos dialógicos.

Tendo em vista essa circunstância colocada por Luca e Andrade (2013) e a importância do aprofundamento da compreensão de como os princípios da EA construídos historicamente vem se fazendo presentes nos processos educadores, esta pesquisa teve como objetivo geral: contribuir para o aprofundamento de conhecimentos sobre o diálogo no campo da Educação Ambiental. Para isso, buscou-se analisar como se deu o processo educador desenvolvido pela organização não governamental supracitada com pescadores artesanais marítimos, respondendo a seguinte pergunta de pesquisa: As atividades de EA e de pesquisa desenvolvidas por uma ONG com pescadores artesanais marítimos do litoral paulista contribuíram para fomentar o diálogo entre a ONG e os pescadores em busca de uma transição para a pesca responsável e da melhoria das condições existenciais dos pescadores?

\footnotetext{
${ }^{1}$ YANKELOVICH, D. The magic of dialogue: transforming conflict into cooperation. New York: Touchstone, 2001.

2 ISAACS, W. Taking flight: dialogue, collective thinking and organizational learning. Organizational Dynamics, vol. 22, issue 2, 1993.
} 
De um lado, um importante ator dentro do movimento ambientalista, buscando promover transformações socioambientais. De outro, pescadores artesanais, sujeitos que guardam em suas tradições formas diferentes de se relacionar com a natureza. Esses atores têm seus caminhos cruzados quando os primeiros propõem processos educadores ambientalistas a serem realizados com os segundos, almejando tratar da proteção de espécies ameaçadas, da poluição marinha, do consumo exagerado, da situação da atividade pesqueira, entre outros.

Evidenciada a necessidade de aprofundar o conhecimento sobre o exercício do diálogo, como forma de aprimorar ações de educação ambiental, o trabalho com pescadores artesanais pode ser avaliado para que se construam processos transformadores e não perpetuadores do status quo. Investigar a ocorrência do diálogo enquanto uma postura, individual e coletiva, e um caminho metodológico na relação entre ONG e pescadores artesanais na busca por uma transição para a pesca responsável, a partir da realização de um processo de EA, se demonstrou instigante e desafiador.

Assim, foram formulados quatro objetivos específicos para a investigação desse caso:

1. Contribuir para a compreensão de condicionantes históricas ligadas às Organizações Não Governamentais e aos Pescadores Artesanais Marítimos na formação da identidade desses grupos na sociedade, a partir dos preceitos dialógicos.

2. Identificar as percepções de integrantes de uma ONG e de um conjunto de pescadores artesanais sobre o processo educador em foco, voltado à situação atual da pesca, captura acidental de golfinhos e tartarugas marinhas e a colaboração entre organizações e comunidades tradicionais.

3. Identificar se o diálogo permeou as relações entre ONG e pescadores artesanais marítimos ao longo do processo educador ambientalista proposto pela primeira aos segundos em busca de uma transição para a pesca responsável.

4. Identificar estratégias utilizadas pelos dois atores sociais no fomento, ou não, ao diálogo nos encontros de educação ambiental e de pesquisa. 


\section{INTRODUÇÃO}

\subsection{Concepções de Educação Ambiental}

A partir do histórico da educação ambiental (EA) apresentado por autores como Sorrentino (1995), Dias (2004), Layrargues (2004), Sauvé (2005), Czapski (2009) é possível notar a evolução da concepção de educação ambiental, partindo de uma visão ligada apenas a aspectos do ambiente natural, como flora e fauna, chegando a uma concepção mais complexa por considerar aspectos sociais, culturais, econômicos, políticos, éticos, além dos ambientais, de maneira interdisciplinar e transdisciplinar em diferentes escalas espaciais, tanto local quanto global.

No entanto, tal evolução não significa que se chegou a uma concepção única e bem definida do que seja a educação ambiental. Ao contrário, têm-se múltiplas visões sobre a forma de conceber e praticar a EA coexistindo entre os diversos grupos de atores envolvidos com a temática, variando desde concepções mais pontuais, focadas na solução de um problema ou na realização de uma estratégia ou técnica, até concepções mais complexas, envolvendo um múltiplo ferramental analítico e crítico.

Sauvé (2005) realizou um mapeamento das correntes de EA existentes, cada uma caracterizada por conceitos e práticas próprias. Ao todo listou quinze correntes dividas em dois grandes grupos. O primeiro caracterizado pelas correntes de longa tradição correspondente às décadas de 1970 e 1980, sendo elas: a naturalista, a conservacionista/recursista, a resolutiva, a sistêmica, a científica, a humanista e a moral/ética. Já o segundo é caracterizado por correntes mais recentes: a holística, a biorregionalista, a práxica, a crítica, a feminista, a etnográfica, a eco-educação e a da sustentabilidade.

Além disso, a publicação "Identidades da Educação Ambiental Brasileira" do Ministério do Meio Ambiente (MMA), coordenada por Layrargues (2004), traz uma série de textos de diferentes autores para tratar das especificações existentes para a EA brasileira, como a educação ambiental crítica, a ecopedagogia, a alfabetização ecológica, a educação ambiental transformadora ou emancipatória e a educação ambiental no processo de gestão ambiental, mostrando suas diferentes identidades.

Porém, os autores supracitados (SAUVÉ, 2005; LAYRARGUES, 2004) e Iared et. al. (2011) alertam para o fato de tais divisões não serem rígidas, uma vez que existem 
características comuns entre as várias correntes, além de ser possível seguir os princípios e práticas de mais de uma.

Tendo em vista essa diversidade de concepções ao se trabalhar com a educação ambiental, se faz necessário explicitar quais são os conceitos e métodos adotados. Assim, nesta pesquisa adota-se a concepção desenvolvida pelo Laboratório de Educação e Política Ambiental - Oca, da Escola Superior de Agricultura Luiz de Queiroz (ESALQ) da Universidade de São Paulo (USP) apresentada a seguir.

Para a Oca há cinco pilares para o desenvolvimento de uma educação ambiental que almeje promover a transição para sociedades sustentáveis, são eles: comunidade; identidade; diálogo, pilar escolhido para ser analisado nesta pesquisa; potência de ação e felicidade (SORRENTINO et. al., 2013).

Comunidade é entendida não apenas como um espaço geográfico, mas como um conceito existencial, de acordo com as ideias de Gusfield $(1995)^{3}$ citadas por Sorrentino et. al. (2013), abrigando um grupo de pessoas e permitindo organizar as relações entre os indivíduos do grupo, estimulando o sentimento de pertencimento e de identidade comum, assim como a solidariedade. Para estimular o surgimento dessa comunidade a Oca adota os conceitos de comunidades interpretativas de Boaventura de S. Santos e as de comunidades aprendentes de Carlos R. Brandão (SORRENTINO et. al., 2013).

O pilar identidade se caracteriza pela construção de um autoconhecimento, de um sentimento de pertencimento e de um compromisso local e planetário que possibilite desvelar diferentes formas de agir para o enfrentamento das diversas questões sociais e ambientais. Assim, a educação ambiental busca contribuir para a construção de identidades que compreendam o contexto, se posicionem diante de utopias e distopias, suas e de terceiros, partindo de análises que busquem compreender a totalidade da problemática ambiental (SORRENTINO et. al., 2013).

O diálogo, por sua vez, é o caminho pelo qual se permite a criação das identidades uma vez que possibilita entender a si próprio e ao outro, criando significados comuns e, portanto, uma amálgama entre as diversidades. Assim, o diálogo se constitui enquanto "[...] a via de acesso para a democratização das identidades e saberes diversos." (SORRENTINO et. al., 2013, p. 37).

\footnotetext{
${ }^{3}$ GUSFIELD, J. R. Community: a critical response. New York: Harper \& Row Publications, 1995.
} 
A potência de ação é apresentada a partir das ideias de Espinosa, filósofo do século XVII, em paralelo com a ideia de participação, se referindo ao encontro com o outro. Este pode ser definido enquanto um bom encontro ou um mau encontro. O primeiro se caracteriza por aumentar a potência de ação do indivíduo, entendida como "a emergência da capacidade de agir em direção à transformação que queremos [...]" (SORRENTINO et. al., 2013, p. 43), enquanto o segundo se caracteriza por diminuir a potência de ação. Assim, a potência gerada por um bom encontro possibilita a participação de homens e mulheres em processos de mobilização que buscam realizar ações transformadoras da realidade (SORRENTINO et. al., 2013).

A felicidade, por sua vez, é um conceito muito discutido. A ideia de felicidade desenvolvida a partir do paradigma da razão, pregado pelos iluministas, está ligada à transformação da realidade em busca dos desejos individuais. Tal postura individualista e competitiva tem levado à ideia de felicidade enquanto um produto a ser adquirido, algo externo ao indivíduo que preencherá seu vazio existencial. Tal concepção tem sido questionada a partir de ideias de pensadores orientais, como Krishnamurti, afirmando que a felicidade se encontra dentro de cada um. Assim, este tema "[...] pode ser importante porta de entrada e aprofundamento nos processos de Educação Ambiental dialógicos e emancipatórios, possivelmente contribuindo para sua sustentabilidade." (SORRENTINO et. al., 2013, p. 50). Apresentados os cinco pilares da Oca, suas interconexões podem ser expressas da seguinte maneira

Partimos do conceito de Comunidade, em que cada qual busca e exercita sua própria Identidade, individual e coletiva, a partir do Diálogo, cujas descobertas incrementam a Potência de Ação, permitindo que sejamos capazes de iniciar e manter processos que possibilitem a tão almejada Felicidade. (SORENTINO et. al., 2013, p. 22).

Pautada por esses cinco pilares, a Oca tem desenvolvido e aprimorado uma metodologia de educação ambiental intitulada "Método Oca". Este método de intervenção e pesquisa em EA surge da ideia de integrar o "fazer ambientalista" e uma proposta metodológica de pesquisa, sendo caracterizado por uma estrutura dialógica-incremental, na qual há uma flexibilidade quanto aos procedimentos adotados, não se constituindo, portanto, enquanto uma fórmula fixa (OCA, 2016).

Tal método possui doze componentes entendidos como necessários para realizar intervenções educadoras ambientalistas que busquem a transição para sociedades sustentáveis, são eles: temática problematizadora socioambiental; círculo de cultura; mergulhar em si 
próprio; conjuntura e utopia; planejamento participativo, incremental e articulado; estudar, ler, aprender e pesquisar; mapeamentos e diagnósticos; intervenção; incidir em políticas públicas; educomunicação; registro, sistematização, monitoramento e avaliação; e cardápio de conteúdos (OCA, 2016).

\subsection{Educação Ambiental e Diálogo}

De acordo com importantes documentos nacionais (Programa Nacional de Educação Ambiental [ProNEA] e Programa de Formação de Educadoras(es) Ambientais [ProFEA]) (ÓRGÃO GESTOR DA PNEA, 2006; 2014) e internacionais (Tratado de Educação Ambiental para Sociedades Sustentáveis e Responsabilidade Global [TEASS]) (FÓRUM GLOBAL DAS ONGs, 1992) de EA, o diálogo se constitui, ao mesmo tempo, enquanto importante princípio e objetivo da mesma. De acordo com o TEASS

A educação ambiental deve promover a cooperação e o diálogo entre indivíduos e instituições, com a finalidade de criar novos modos de vida, baseados em atender às necessidades básicas de todos, sem distinções étnicas, físicas, de gênero, idade, religião ou classe. (FÓRUM GLOBAL DAS ONGs, 1992, p. 2, negrito nosso).

Seguindo tais recomendações, o Programa Nacional de Educação Ambiental (ProNEA) elaborado pelo MMA e MEC “estimula o diálogo interdisciplinar entre as políticas setoriais e a participação qualificada nas decisões sobre investimentos, monitoramento e avaliação do impacto de tais políticas.” (ÓRGÃO GESTOR DA PNEA, 2014, p. 23)

O Programa Nacional de Formação de Educadoras (es) Ambientais (ProFEA), também baseado no TEASS, traz, por sua vez, que "A relação educador(a)-educanda(o) é um encontro de saberes, um diálogo democrático sobre a realidade vivida, não há saberes mais importantes, não há hierarquia de conhecimentos." (ÓRGÃO GESTOR DA PNEA, 2006, p. 8, negrito nosso). Além disso, visando a realização de intervenções educacionais críticas e emancipatórias afirma que

Deve-se desenvolver um diálogo interpretativo a partir das distintas leituras da realidade vivenciada, da enunciação do futuro desejado e da formulação das distintas propostas, projetos, ações, estudos para enfrentamento das problemáticas (dentro do marco da complexidade) e transformação da realidade socioambiental no sentido da sustentabilidade e da felicidade. (p. 11, negrito nosso).

Sorrentino et. al. (2013) afirmam que estimular o diálogo se constitui enquanto um desafio e uma necessidade para a realização de uma EA "que fortalece e confere autonomia e confiança aos indivíduos, que promove a coexistência equilibrada entre as realidades e 
contextos pessoais e coletivos, entre o moderno e as tradições, entre a tecnologia e o jeito simples de ser." (p. 37). Nesse sentido, Sorrentino (2014) enuncia que o objetivo maior dos processos educadores ambientalistas é a promoção do acesso ao diálogo empoderador entre os sujeitos que deles participam.

O diálogo crítico e acolhedor que permite a tomada de posições pautadas nas próprias convicções e na capacidade de revê-las e incrementá-las em direção à construção do seu projeto de futuro, dos seus sonhos e utopias. Diálogo que permita abrir-se ao próximo e planejar e avaliar juntos. Diálogo consigo mesmo, com os ventos, com as árvores, com os animais, com outros seres e energias que povoam os nossos sentimentos, a nossa alma e enriquecem o nosso espírito. Diálogo com a sociedade, procurando entende-la criticamente, historicamente, conjunturalmente, em toda a sua estrutura e contradições, de forma a sentir-se potente para transformá-la com os outros e para o bem de todos. Diálogo voltado à superação das posturas e ações competitivas, intolerantes, homogeneizadoras, machistas, massificantes, imediatistas, predatórias e gananciosas, para o incremento dos conhecimentos e compromissos de toda a humanidade e de cada um com a VIDA, a democracia, a solidariedade, o repúdio a todo e qualquer tipo de totalitarismo, a diversidade, a paz, a justiça, o amor e a emancipação humana. (SORRENTINO, 2014, p. 147).

Figueiredo (2006), por sua vez, apresenta a concepção de uma Educação Ambiental Dialógica (EAD) pautada nas ideias freireanas, afirmando a importância de se trabalhar a problemática ambiental a partir das várias dimensões que compõem a realidade: social, econômica, cultural, científica, tecnológica, ética, espiritual e ecológica, sem se limitar apenas a esta última. Nesse sentido, o autor enuncia os diversos princípios adotados em tal concepção de EA, sendo eles:

o diálogo democrático como elemento primordial; considerar o aprendente como autor ativo e a contextualização como essencial no processo educativo; a supra-alteridade que valoriza o outro como legítimo outro; o saber parceiro. Princípios como a solidariedade, a eqüidade, a postura crítica, a trans-ação, a politicidade do ato educativo; a inter/transdisciplinaridade, a multirreferencialidade, a leitura de mundo em teia; a resolução concreta de questões ambientais em sua multidimensionalidade; a noção de integralidade; o foco nas relações, a ecopráxis, a multidimensionalidade humana. (FIGUEIREDO, 2006, p. 2).

O autor agrega a essa concepção de EA a Perspectiva Eco-Relacional (PER), a qual enfatiza a relação como eixo principal do processo educador, entendendo e afirmando a necessidade de se considerar as relações humanas e sociais dentro da questão ambiental, reconhecendo a complexidade e a importância de se considerar a totalidade, rompendo com o paradigma fragmentador cartesiano (FIGUEIREDO, 2003). Detalha a PER trazendo os sete eixos que a caracterizam: 
1) Prioriza o 'relacional' como contexto básico e as relações como princípio do real; 2) O termo 'eco', reforça a conjuntura ecossistêmica, as interações sociais entre o vivo e o considerado não-vivo da natureza. Está interligado com o 'oikos' (morada), informando o contexto de manifestação das relações, o espaço relacional [...] 3) O eco-relacional retrata o interativo de 'tudo com tudo' e toda a totalidade. [...] 4) Explicita a complexidade e abrangência presente e retratada no contexto da evolução das formas de vida. [...] 5) O argumento essencial dessa perspectiva é poder representar uma boa resposta para a crise atual de paradigmas. [...] 6) Essa perspectiva crítica considera que toda amplitude, interior e exterior, objetiva, subjetiva e intersubjetiva se entrelaçam, [...] podendo levar desde o processo de sensibilização, "alfabetização" eco-relacional, à prática eco-relacional (ecopráxis); 7) A dimensão ética emerge como esfera essencial. (FIGUEIREDO, 2003, p. 45-46, itálico do autor).

Trabalhando também a partir das ideias freireanas, Logarezzi (2010) sugere uma Educação Ambiental acompanhada pelo qualificativo “crítico-dialógica”. A perspectiva crítica aqui " [...] inclui a denúncia das contradições sociais enquanto base da destruição ambiental, e coloca esta relação como fundamento para a ação de enfrentamento das contradições, sendo ação anunciadora e portanto transformadora.” (p. 13). O qualificativo "dialógica" traz em si o reconhecimento da incompletude humana, a necessidade de tomada de posição política frente à realidade e coloca a interação/relação como o elemento central do processo educador ambientalista.

No entanto, Andrade e Sorrentino (2014a; 2014b) alertam para um perigo bastante sério em se tratando da Educação Ambiental. Esta se constitui enquanto uma invenção ocidental para tentar mitigar os problemas ambientais criados pelo próprio Ocidente, o qual se caracteriza por uma postura ativa de dominação do outro, considerado objeto, a ser catequizado, no caso dos indígenas, ou impulsionado em direção ao progresso, no caso dos países em desenvolvimento.

Esse processo de colonização tem a educação como um forte instrumento de dominação, na medida em que esta prescreve princípios, atitudes e comportamentos adequados do ponto de vista do colonizador. E muitas vezes, mesmo que de forma não intencional, os educadores se constituem enquanto agentes do processo colonizador, pois “à medida que compreendemos o outro enquanto objeto que necessita de orientação e supervisão, nós sentimos que é nosso dever, mesmo subconscientemente, impor nossos valores e interesses aos outros." (ANDRADE; SORRENTINO, 2014b, p. 148, tradução 
nossa ${ }^{4}$ ). Andrade e Sorrentino (2014a) complementam tal pensamento ao tratar da relação entre educadores ambientais e comunidades tradicionais, afirmando que

Uma reunião em que representantes da cultura ocidental se encontram com membros de comunidades tradicionais e rurais é repleta de obstáculos ao diálogo. Como a cultura ocidental é predominante em todo o mundo os seus representantes são, quase que automaticamente, considerados mais poderosos. Não só eles são vistos como dominantes no geral, mas demonstram essa condição continuamente por serem escolarizados, eruditos com palavras e sofisticados em termos de posse de tecnologias (que são valorizadas no Ocidente), as roupas usadas e assim por diante. Em um contexto hipotético (e muito estereotipado) como esse, a boa vontade para o diálogo está longe de ser suficiente. (p. 668).

Além disso, a postura produtivista ligada ao modelo urbano-industrial contribui para a emergência de dois importantes obstáculos, muito presentes, para o diálogo na prática educadora: a falta de tempo das pessoas para participar e a mentalidade ligada à necessidade de atingir resultados e desenvolver produtos (LUCA; ANDRADE, 2013).

Dessa forma, o diálogo se constitui num modo de se libertar desse modelo colonizador, pois

Ao propiciar as condições em que as influências sutis e tácitas sobre o pensamento sejam alteradas, o diálogo possibilita uma transformação da natureza da consciência, permitindo a emergência de novos tipos de inteligências individuais e coletivas, em substituição dos padrões mentais existentes quando as questões surgiram. E esse novo tipo de inteligência pode potencializar a ação [transformadora da realidade] [...] (SORRENTINO et. al., 2013, p. 41).

Ademais, ao assumir o diálogo enquanto um princípio do fazer educativo ambiental é necessário a identificação dos obstáculos existentes no encontro dialógico e o constante exercício em busca de sua resolução, o que demanda tempo e métodos diferentes dos utilizados pelo sistema educacional vigente (ANDRADE; SORRENTINO, 2014a), haja vista que

Pedagogias ocidentais tradicionais são marcadamente não dialógicas, hierárquicas e isoladoras, de modo que a realização do diálogo nos convida a pensar diferente, em dinâmicas inovadoras que possam nos ajudar a superar nossas distâncias em relação aos outros. (ANDRADE; SORRENTINO, 2014a, p. 670).

Sobre as metodologias dialógicas já utilizadas na EA, como a árvore dos sonhos, o muro das lamentações (INSTITUTO ECOAR PARA A CIDADANIA, 2008) e outras, Andrade e Sorrentino (2014b) apontam a "[...] tentativa [dessas atividades] de incluir

\footnotetext{
4 "As we comprehend the other as an object who needs guidance and supervision, we feel it is our duty to, even subconsciously, impose our values and interests onto others." (p.148)
} 
radicalmente os participantes, promover a investigação e o pensamento crítico, observação, criatividade, proatividade e a criação de significados coletivos.” (p. 150, tradução nossa ${ }^{5}$ ) à medida que reforçam constantemente a importância do outro. Além disso, os autores afirmam que essas atividades são "cheias de intenções" pedagógicas e políticas, ou seja, com pressupostos, “[...] mas essas intenções não são fortes a ponto de ofuscar ou desencorajar as capacidades dos participantes de refletir e questionar fora de um caminho predefinido." (p. 150, tradução nossa ${ }^{6}$ ), permitindo o desenvolvimento da autonomia e da criticidade.

Assim, um dos principais desafios postos hoje para a EA é a elaboração e implementação de pedagogias dialógicas em contextos formais e não-formais de educação, de forma que as educadoras(es) ambientais devem estar sempre se questionando sobre suas práticas à luz deste pressuposto. Devem reconhecer a posição social e histórica que ocupam, ou seja, sua marca ocidental para que não se iludam acreditando serem agentes promotores de mudanças quando na verdade suas ações podem estar perpetuando o status quo (ANDRADE; SORRENTINO, 2014a).

A aproximação entre sociedade ocidental industrializada e culturas tradicionais, as quais parecem manter um estilo de vida mais sustentável, deve ser feita pela educação dialógica, reconhecendo os limites da visão ocidental e o respeito às diferenças, ao outro em sua completude, para que transformações nas sociedades industriais degradadoras das relações humanas e do ambiente possam ocorrer (ANDRADE e SORRENTINO, 2014b). E para isso é relevante a realização de pesquisas que aprofundem a compressão do diálogo, bem como sua teoria operacional, buscando a formulação de indicadores que auxiliem no processo de entendimento da dialogicidade no fazer educador (ANDRADE; LUCA; SORRENTINO, 2012; LUCA; ANDRADE, 2013).

\subsection{O Diálogo permeando pesquisas científicas}

Alguns trabalhos foram desenvolvidos tendo o diálogo como objeto de pesquisa. Xavier e Szymanski (2015) investigaram as percepções que os atores envolvidos em suas pesquisas tiveram sobre o diálogo após experiências dialógicas, tendo como resultados o entendimento daquele enquanto "conversa", "participação", "silêncio", "integração" e “construção de conhecimento".

\footnotetext{
5 "an attempt to include participants radically, to foster critical thinking and enquiry, observation, creativity, proactivity and the creation of collective meanings." (p. 150)

6 "but this intention is not as strong as to overshadow or discourage participants' capacities of wandering and wondering outside a predefined path.” (p. 150)
} 
Ferreira (2011) realizou uma pesquisa para investigar, a partir da percepção de tutores de um curso à distância, como que as estratégias de interação utilizadas por eles com os alunos contribuem para um processo dialógico de aprendizagem, verificando que para a ocorrência de tal cenário é preciso que os tutores assumam tal postura na sua prática.

Gabassa (2009) investigou o diálogo no contexto escolar, especificamente na aula de professoras, constatando que o sistema, entendido como as instituições, não oferece possibilidades de promoção do diálogo, mas sim de obstaculizá-lo. Além disso, verificou, assim como Ferreira (2011), que a construção de aulas dialógicas depende da postura da professora, a partir do reconhecimento de que ao mesmo tempo em que ensina, aprende com os estudantes.

Continuando no contexto escolar, Ferreira (2005) analisou o diálogo na relação escolacomunidade, evidenciando o caráter flexível da escola, a qual se reelabora constantemente no processo de construção de saberes, de forma que seus educadores buscam mobilizar tais saberes almejando o estabelecimento da relação dialógica com a comunidade.

Oliveira (2003), por sua vez, realizou um trabalho para investigar quais os processos educativos existentes na relação entre comunidades que se unem em prol de determinada causa. Nesse contexto, abordou o tema do diálogo com os participantes da pesquisa. A partir dos depoimentos dos entrevistados pôde verificar que os mesmos buscam-no em suas ações, entendendo que para sua ocorrência "são necessárias motivações políticas e existenciais, afetividade, gostar de estar na comunidade.” (p. 122).

Em se tratando do diálogo em pesquisas de Educação Ambiental há aquelas que o abordaram enquanto objeto de investigação e as que o utilizaram como caminho teóricometodológico. Andrade (2013) investigou em sua tese de doutorado a ocorrência do diálogo num processo de construção de uma política pública de educação ambiental, a criação do Coletivo Educador Ambiental (CEA) em um município paulista.

Para isso utilizou análise de documentos, observação participante, entrevistas e grupo focal. Notou muitas fragilidades institucionais para a ocorrência do diálogo a partir dos seguintes indicadores: a suspensão de pressupostos; a existência de gestos que explicitam o desejo de se humanizar a conversa; a emergência de confrontos; o surgimento de afinidades entre as pessoas (ANDRADE, 2013). 
Analisando as instituições de meio ambiente do município em questão verificou a existência de obstáculos ao diálogo na constituição do CEA, como: a incorporação incipiente do diálogo na prática dos indivíduos da pesquisa; o pensamento fragmentado; a contradição entre desejos individuais e práticas; a falta de habilidades pessoais para trabalhar o diálogo. Por outro lado, verificou uma potencialidade dialógica bastante grande, uma vez que as instituições analisadas podem construir coletivamente os princípios e objetivos da educação ambiental do município (ANDRADE, 2013).

Avanzi (2005) buscou, a partir do processo de produção de um grupo de pesquisa, identificar elementos que subsidiassem aspectos teórico-metodológicos de uma EA dialógica, encontrando: a importância de se explicitar a relação entre sujeitos-historicidade-ambiente; a participação como exercício de diálogo; a educação como prática social.

Lima (2014) investigou a relação entre educadores e educandos de uma escola indígena a partir dos princípios de uma EA dialógica na perspectiva eco-relacional de Figueiredo $(2003$; 2006). Para isso, estabeleceu um paralelo entre diálogo e a descolonização da vida, encontrando "[...] uma mistura de colonialidade e descolonialidade no cotidiano escolar.” (p. 297) e identificando um potencial para o exercício dialógico descolonizante.

Silva (2016) realizou uma investigação-ação junto a estudantes ribeirinhos de uma escola, a partir dos princípios teóricos e metodológicos de uma pedagogia dialógicoproblematizadora, pautada nas ideias freireanas, defendendo que tal caminho permite uma maior integração entre os eixos temáticos trabalhos na escola, assim como fortalece o empoderamento em cada sujeito participante do processo educador.

Roese (2014) buscou demonstrar como a aprendizagem dialógica pode ser um caminho interessante para a educação ambiental crítica que busca fomentar a transformação social, investigando "[...] os limites e as potencialidades do desenvolvimento de programas de EA para a conservação de animais predadores de topo de cadeia no entorno de áreas protegidas do interior de São Paulo.” (p. 20).

Souza (2017), em sua tese de doutorado, buscou identificar, a partir dos princípios de uma EA dialógico-crítica, os elementos obstaculizadores e os elementos transformadores da prática social da pesca artesanal realizada no município de Cáceres/MT. Para isso utilizou a Metodologia Comunicativo-Crítica (MCC) de Gómez et. al. (2006) ${ }^{7}$, permitindo que

\footnotetext{
${ }^{7}$ GOMÉZ, J.; LATORE, A.; SÁCHES, M.; FLECHA, R. Metodologia comunicativa crítica. Barcelona: El Roure Editorial, 2006. 149 p.
} 
dialogasse com os sujeitos da pesquisa, a qual se constituiu enquanto um processo formativo dialógico e crítico, em que se desvelou as contradições vividas pelos mesmos.

Dentre os resultados encontrados, em relação aos elementos obstaculizadores ele apresenta a desesperança; as ameaçadas ao território e à cultura da pesca artesanal; a baixa dialogicidade entre pescadores e organização representante (colônia e associação); a falta de espaço de diálogo para incidir nos processos de formulação de políticas públicas estatais ligadas à pesca. Sobre os elementos transformadores pôde identificar a confiança e a solidariedade entre as(os) pescadoras(es), realizando uma discussão sobre a ética tradicional ribeirinha pantaneira (SOUZA, 2017).

Portanto, considerando os resultados encontrados pelas pesquisas supracitadas quanto ao diálogo é possível notar a importância de se aprofundar a concepção de diálogo daqueles que participam de um momento que se pretende dialógico (OLIVEIRA, 2003; XAVIER; SZYMANSKI, 2015) e de assumir a postura dialógica na prática educacional (FERREIRA, 2005; FERREIRA, 2011; GABASSA, 2009). Além disso, é de vital importância identificar os aspectos fomentadores e opressores do diálogo (ANDRADE, 2013; SOUZA, 2017), reforçando, assim, a importância da realização de pesquisas que investiguem o diálogo em processos de educação ambiental (AVANZI, 2005; LIMA, 2014; SILVA, 2016; ROESE, 2014), com o intuito de aprofundar e aprimorar as práticas de EA que se propõem dialógicas.

\subsection{Diálogo}

Tendo em vista o exposto até aqui, a concepção de diálogo utilizada nesta pesquisa se constitui numa síntese das ideias de Martin Buber, David Bohm, William Isaacs e Paulo Freire, sendo apresentado a seguir o conceito, a noção de uma existência dialógica e caminhos possíveis para atingi-la.

\subsubsection{O conceito}

A etimologia da palavra diálogo vem do grego diálogos. Dia significa "através" e logos "a palavra" ou "significado da palavra", sugerindo a imagem "[...] de uma corrente de significados que flui entre nós e por nosso intermédio; que nos atravessa enfim.” (BOHM, 2005, p. 34). Assim o diálogo pode ser entendido como o fluir de significados por meio da palavra.

Pode ser entendido também como 
[...] uma conversa com um centro e não lados. É um caminho para pegar a energia de nossas diferenças e canalizá-la em direção de algo que nunca tenha sido criado antes. Isso nos retira da polarização e nos conduz para um senso comum maior e, desse modo, é um meio para acessar a inteligência e o poder de grupos de pessoas. (ISAACS, 1999, p. 19, tradução nossa).

O diálogo possibilita que as pessoas pensem juntas, de forma a não se prender em opiniões pré-estabelecidas e se livrando das "certezas" adquiridas ao longo da vida, permitindo mudanças na identidade dos envolvidos em tal processo, uma vez que percebem ser mais do que pensavam ser (ISAACS, 1999; 2012).

Nesse sentido, o diálogo pode se caracterizar por ser o "encontro dos homens [e mulheres], mediatizados pelo mundo, para pronunciá-lo [...]” (FREIRE, 1981, p. 93, itálico do autor), pronúncia que se dá por meio da palavra verdadeira, a qual se constitui por ser simultaneamente ação e reflexão, ou seja, práxis.

Uma vez pronunciado, o mundo volta problematizado para os pronunciantes exigindo deles um novo pronunciar (FREIRE, 1981). Na medida em que esse ciclo virtuoso vai se desenvolvendo a transformação do mundo vai ganhando cada vez mais possibilidade de ocorrer, uma vez que os atores envolvidos no diálogo estão desvelando a realidade, objetivando-a, e reconhecendo, por sua vez, a limitação do conhecimento que possuem, o que permite o desenvolvimento do pensar e agir críticos (FREIRE; SHOR, 1986). Portanto, o diálogo é uma exigência existencial, na medida em que "se é dizendo a palavra com que, "pronunciando" o mundo, os homens [e as mulheres] o transformam, o diálogo se impõe como caminho pelo qual os homens [e as mulheres] ganham significação enquanto homens [ou mulheres].” (FREIRE, 1981, p. 93).

Dessa forma, fica claro que diálogo não é o mesmo que discussão ou debate. Nessas modalidades de conversa se estabelece uma disputa de ideias, na qual se tem um vencedor e um perdedor. Numa conversa dialógica ocorre exatamente o oposto, só há vencedores. Além disso, o diálogo permite o surgimento de novas compreensões, a partir do compartilhamento do significado. "Esse significado compartilhado é a 'cola' ou 'amálgama' que mantém juntas as pessoas e as sociedades.” (BOHM, 2005, p. 34).

\subsubsection{A existência dialógica e sua espiral}

Os três autores supracitados (David Bohm, William Isaacs e Paulo Freire) desenvolveram suas concepções de diálogo tendo como uma de suas principais referências o filósofo e educador austríaco Martin Buber (1878 - 1965). Este apresentou a ideia de uma existência dialógica, a qual traz em si uma concepção mais ontológica do diálogo. 
Buber (2014) enuncia dois tipos de existência: a monológica e a dialógica. A primeira se caracteriza por um dobrar-se em si mesmo, por uma objetificação do outro, reconhecido apenas como um meio para a vivência própria. Já a existência dialógica é caracterizada pela relação de reciprocidade entre os Seres, de forma que o voltar-se para o Outro se institui e, assim, a comunhão acontece. Aqui a postura que se faz presente é a da tomada de conhecimento íntimo do Outro, o que significa "[...] experienciá-lo como uma totalidade e, contudo, ao mesmo tempo, sem abstrações que o reduzam, experienciá-lo em toda a sua concretude." (BUBER, 2014, p. 147, negrito nosso).

Ao entrar nesse tipo de relação é possível reconhecer o Outro como ele é e não como parece ser, implicando assim numa responsabilidade dialógica, genuína, que demanda por sua vez em um responder verdadeiro, entendido como "responder ao que nos acontece, que nos é dado ver, ouvir, sentir." (BUBER, 2014, p. 49), ou seja, enunciar aquilo que de verdadeiro existe dentro de cada um.

Essa existência dialógica é caracterizada pela palavra-princípio Eu-Tu. A relação é o que marca essa palavra-princípio, dando-se numa troca muito profunda na qual o Eu e o Tu participam ativamente e ao fazê-lo estão inteiros, em suas totalidades, e não fragmentados por uma necessidade particular. "Quem diz TU [...] permanece em relação.” (BUBER, 1979, p. 29, negrito nosso).

A totalidade é algo que ocorre entre o Eu e o Tu, ou seja, juntos são totalidade, separados são parcialidade. "A união e a fusão em um ser total não pode ser realizada por mim e nem pode ser efetivada sem mim. O EU se realiza na relação com o TU; é tornando EU que digo TU. Toda vida atual é encontro.”(BUBER, 1979, p. 33).

Outro ponto importante da relação Eu-Tu é que o Tu se encontra com o Eu. Não há uma busca deste por aquele. No entanto, ao se encontrarem é o EU que entra em relação imediata com o TU (BUBER, 1979).

A relação com o TU é imediata. Entre o EU e o TU não se interpõe nenhum jogo de conceitos, nenhum esquema, nenhuma fantasia; e a própria memória se transforma no momento em que passa dos detalhes à totalidade. Entre EU e o TU não há fim algum, nenhuma avidez ou antecipação; e a própria aspiração se transforma no momento em que passa do sonho à realidade. Todo meio é obstáculo. Somente na medida em que todos os meios são abolidos, acontece o encontro. (BUBER, 1979, p. 33).

Buber (1979) alerta que "[...] a grande melancolia de nosso destino é que cada TU em nosso mundo deve tornar-se irremediavelmente um ISSO.” (p. 35). Após o encontro, marcado por esse contato profundo, o Tu se torna um objeto, quantificável e descritível. "Cada TU 
neste mundo é condenado, pela sua própria essência, a tornar-se uma coisa, ou então, a sempre retornar à coisidade." (p. 35). Porém, esse é o processo pelo qual as relações do Eu acontecem, um entrelaçamento entre momentos que ora se estabelecem com o Tu e ora com o Isso. "Cada TU, após o término do evento da relação deve necessariamente se transformar em ISSO. Cada ISSO pode, se entrar no evento da relação, tornar-se um TU.” (p. 42)

Frente ao exposto, Buber (1979) afirma que nosso modo de vida está cada vez mais dominado pelo mundo do Isso e assim se faz necessário resgatar a dimensão do encontro com o Tu, a busca pela existência dialógica, para que homens e mulheres não percam sua essência humana.

Nesse sentido, Freire, Bohm e Isaacs apresentam caminhos metodológicos para se viver uma existência dialógica. Para Freire $(1981$; 1983) tal existência se caracteriza pela ausência de opressão de um Ser pelo outro, na qual haja liberdade para que cada indivíduo possa se perceber num constante processo de vir a ser, no qual está sendo e, portanto, se constituindo enquanto ser humano. Para Bohm $(1980 ; 2005)$ e Isaacs $(1993 ; 1999)$ é aquela em que se rompe com a lógica mecanicista e fragmentadora do pensamento, adotando a ordem implicada.

Os caminhos metodológicos apresentados pelos autores supracitados se caracterizam por um exercício individual e coletivo que se concretiza por meio da relação entre as pessoas, mediatizada pelo desvelamento da cultura a partir de uma compreensão da totalidade em que vivem. O caminho sugerido por Bohm (2005) e Isaacs $(1993 ; 1999 ; 2012)$ é a constituição de grupos de diálogo, no qual um grupo de pessoas se reúne para realizar o exercício de suspensão dos pressupostos. Freire $(1981 ; 1983)$, por sua vez, sugere como caminho os círculos de cultura, no qual os participantes realizam o exercício da codificação e descodificação.

Dessa forma, é possível perceber que a existência dialógica, proposta por Buber, se constitui enquanto um processo permanente e continuado e por isso não pode ser encarada como um estágio final a que se almeja chegar. Tal processo pode se dar por uma infinidade de caminhos, como os propostos por Freire, Bohm e Isaacs, ou outros, que permitam a cada pessoa viver em diferentes intensidades uma existência dialógica, criando o movimento de uma Espiral Dialógica (Figura 1). 
Figura 1 - Espiral dialógica e espiral antidialógica

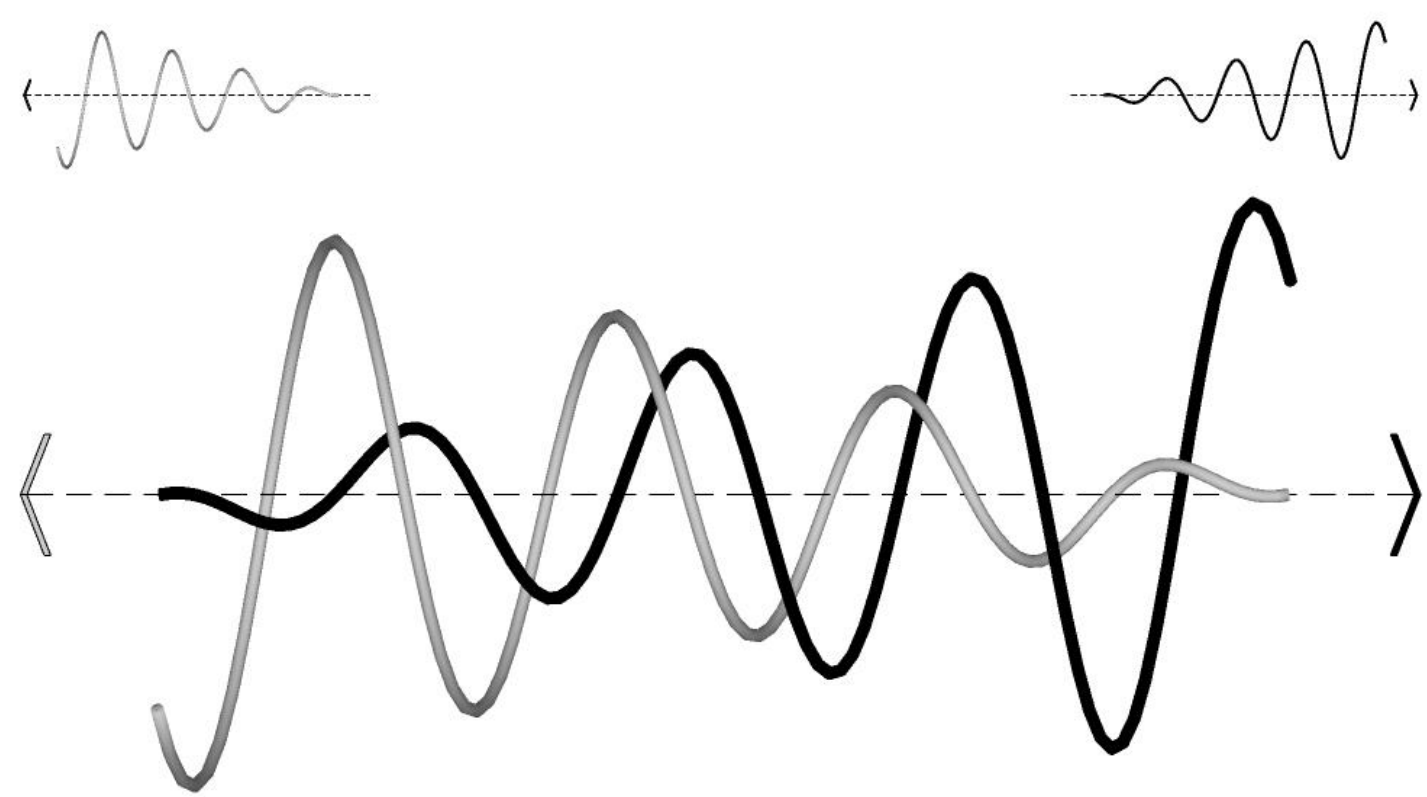

Fonte: Própria, contando com o auxílio do arquiteto Dhiego Torrano para o design da figura.

A Figura 1 mostra duas espirais opostas e sobrepostas, uma cinza e outra preta. Para exemplificar a explicação adotaremos aqui a espiral preta como da existência dialógica e a espiral cinza como da existência antidialógica. Observando a primeira, é possível notar que ela caminha da esquerda para a direita de modo crescente, aumentando a amplitude da espiral, o que representa o incremento da existência dialógica. Assim, em seu início a existência dialógica é muito incipiente e em seu "fim” ela é predominante.

Em oposição está a espiral cinza antidialógica. Essa caminha da direita para esquerda de forma crescente, ou seja, em seu início há a incipiência da antidialogicidade e em seu fim a predominância. A sobreposição entre as espirais permite a compreensão de que quando a antidialogicidade predomina (canto esquerdo da figura) há uma incipiência da dialogicidade e quando esta predomina (canto direito da figura) há uma incipiência daquela.

Portanto, caminhos que permitam o pensar e agir dialógico nos move para o incremento da espiral dialógica, possibilitando a desconstrução da antidialogicidade dentro de nós. Por outro lado, caminhos obstaculizadores do diálogo nos levam a viver uma existência marcada pela antidialogicidade, distanciando-nos de uma vida em que exista a comunhão com o Outro (BUBER, 2014).

A seguir serão apresentados detalhadamente os caminhos propostos por Freire, Bohm e Isaacs, constitutivos da espiral dialógica. 


\subsubsection{Caminhos dialógicos}

\subsubsection{Grupos de diálogo (David Bohm e William Isaacs)}

David Bohm (1917 - 1992), físico teórico norte-americano, apresenta uma visão paradigmática que rompe com a estrutura mecanicista fragmentadora da realidade e das relações entre os Seres. Ele enuncia a existência de uma totalidade indivisa, a qual não se limita ao que podemos ver, sentir, cheirar etc., a que ele chama de Ordem Explicada, mas se constitui também por uma realidade mais sutil e profunda, denominada Ordem Implicada. Esta se caracteriza pela noção de que o todo está em tudo. Cada elemento contém dobrado em si (implicado) a totalidade, o todo (BOHM, 1980).

Afirma que existe um movimento dessa totalidade, o Holomovimento, o qual permite que determinados aspectos da ordem implicada sejam relevados para nós, se constituindo em ordens explicadas. Estas, por sua vez, podem voltar à ordem implicada, dobrando-se novamente. Esse movimento é o que caracteriza essa perspectiva de uma totalidade indivisa e traz um caráter de humildade muito grande frente ao conhecimento, pois nos mostra nossa incapacidade de abarcar esse todo, sendo possível, no entanto, considerá-lo ao se olhar para situações particulares, entendidas como subtotalidades relativamente autônomas (BOHM, 1980).

A grande superação aqui é o reconhecimento paradigmático de que não conhecemos tudo, de que "relevamos" certos aspectos da ordem implicada para explicar determinadas situações circunscritas a determinados contextos, mas que não podem se constituir enquanto generalizações (BOHM, 1980).

Nesse sentido, os grupos de diálogo para Bohm (2005) se constituem enquanto um caminho possível pelo qual se desvela aspectos culturais, entendidos como manifestações relevadas da ordem implicada, para permitir a emergência de novas manifestações dessa ordem até então desconhecidas. Para isso, o autor propõe o exercício da suspensão dos pressupostos básicos que guiam as vidas das pessoas, os quais se caracterizam por suposições prévias a respeito dos mais variados temas, como relações interpessoais, religião, formas de viver a vida etc. (BOHM, 2005).

Num grupo há diversas opiniões baseadas em pressupostos que foram construídos ao longo da história de vida de cada indivíduo, os quais costumam ser defendidos, sob uma carga emocional, quando questionados. Porém, no diálogo é possível substituir tal carga emocional 
por uma postura racional para se observar o que está por trás dos pressupostos (BOHM, 2005).

A imagem que Bohm (2005) propõe é a de “[...] imaginar tudo isso [os pressupostos] suspenso, pendurado diante de seus olhos de modo que possa observá-lo - como o reflexo que vê quando está diante de um espelho.” (p. 55). Para a realização desse exercício é preciso "[...] que você se dê conta das conexões que existem entre os pensamentos que acontecem no diálogo, as sensações corporais e as emoções." (p. 55-56), pois ao perceber esse conjunto de elementos atuando, e geralmente bloqueando a comunicação, ao mesmo tempo em que se está atento ao conteúdo que é comunicado se terá realizado a suspensão.

Aprofundando tais ideias, William Isaacs (1999), estudioso do diálogo na concepção bohmiana e presidente de uma consultoria norte-americana chamada "Dialogos", afirma que há duas formas de realizar a suspensão. A primeira é compartilhando o conteúdo do pensamento, "[...] é abrir, disponibilizar para si e para os outros o conteúdo de sua consciência para que você possa ver o que está acontecendo. [...]. Para fazer isso você precisa localizar, nomear e então expor para os outros o que você conhece [...]" (p. 142, tradução nossa ${ }^{8}$ ). A segunda é entender o processo pelo qual o conteúdo do pensamento foi gerado, de forma que “ao observar os processos do meu pensamento, eu os transformo.” (p. 144, tradução nossa ${ }^{9}$ ).

A suspensão dos pressupostos torna possível a propriocepção (ou auto percepção) do pensamento, caracterizado pelo movimento de perceber a intenção de pensar. O que Bohm (2005) sugere é que se perceba as intenções de pensar, pois acredita que os problemas da humanidade se devem ao fato de o pensamento não possuir tal habilidade. Assim, " $O$ ponto fundamental da suspensão é tornar a propriocepção possível, criar um espelho, de modo que você possa ver os resultados do seu pensamento." (BOHM, 2005, p. 63, itálico do autor), assim como reconhecer os limites dele (BOHM, 1980).

A dificuldade de se realizar tal exercício se deve à fragmentação do pensamento e da compreensão de que o mesmo não é ativo, que ocorre de forma natural, o que se constitui num erro, uma vez que é muito ativo e determina tudo que está a nossa volta. Além disso, “o pensamento defende seus pressupostos básicos contra as evidências de que pode estar equivocado." (BOHM, 2005, p. 41) Por isso, “o propósito do diálogo é percorrer todo o

\footnotetext{
8 “"...] is to disclose, to make available for yourself and others the contentes of your consciousness so you may see what is going on. [...] To do this, you must locate, name, and then display for others what you are aware of [...]" (p. 142)

9 "By observing my thought process in this way, I transform them." (p. 144)
} 
processo do pensamento e mudar o modo como ele acontece coletivamente." (BOHM, 2005, p. 38 negrito nosso).

Dessa forma, o exercício de suspender os pressupostos nos permite romper com o mecanicismo da nossa forma de pensar que condiciona e limita nossos pensamentos, fazendo com que não tenhamos essa noção do todo e de outras formas possíveis de Ser. Isso nos permite questionar as formas de pensar e agir que temos e, assim, ter novos insights, provenientes da ordem implicada (BOHM, 1980; 2005).

Tendo em vista o exposto até aqui fica claro que o diálogo exige e, ao mesmo tempo, promove um campo de conversação particular (ISAACS, 1999), diferente da discussão e debate como já mencionado anteriormente (BOHM, 2005). Um campo de conversação pode ser definido como um espaço no qual há uma qualidade de energia e troca. Esse campo não pode ser criado, mas é possível produzir condições para que um bom campo emerja. Essas condições constituem o "container", composto por aspectos internos, ou emocionais, como as posturas de cada pessoa em ouvir, respeitar, suspender e enunciar, e externos, ou físicos, como a acústica do local, a disposição circular do grupo, número de pessoas etc. Ou seja, os containers "são as características relativamente observáveis dos campos." (ISAACS, 1999, p. 257, tradução nossa ${ }^{10}$ ).

Sobre os aspectos externos, físicos, Bohm (2005) afirma que um grupo de 20 a 40 pessoas é o ideal para se trabalhar. Nessa configuração grupal é possível constatar a presença de um microcosmo da cultura global, de forma que o significado coletivamente compartilhado começa a surgir. E o desafio do diálogo é o de permitir que esse significado seja observado, uma vez que o fato de existir no grupo muitas opiniões e pressupostos diversos implica num pensamento coletivo incoerente, no qual uns pensam $x$, outros y e assim por diante sobre determinado assunto. Por outro lado, o diálogo permite a criação de um pensamento coletivo coerente, visto que se passa a compartilhar um conteúdo comum.

Outra condição externa para a ocorrência do diálogo é a disposição circular dos participantes, uma vez que tal arranjo não gera privilégios. Outro ponto importante é a frequência dos encontros. Podem ser semanais, quinzenais, etc. e durar um, dois ou mais anos. No entanto, não se deve perpetuar um grupo de diálogo. O mais importante não é o tempo que dura, mas que se desenvolva num tempo suficiente para gerar mudanças em seus participantes (BOHM, 2005). Há também a importância da acústica do local do encontro para que todos

10 “[...] are the relatively observable features of fields." (p. 257) 
consigam se ouvir bem e a inexistência de elementos, em tal local, que possam distrair os participantes, perdendo o foco na conversa (ISAACS, 1999).

Sobre os aspectos internos, mentais ou emocionais, estão as quatro ações já mencionadas acima: ouvir, respeitar, suspender e enunciar (ISAACS, 1999). Bohm (2005) afirma que é muito importante que todos tenham a oportunidade de se expressar e de "ouvir livremente", sem preconceitos e sem interesse de influenciar os participantes da conversa, já que havendo tentativas de convencer ou persuadir o outro se terá os pressupostos guiando a conversa, a qual não terá o caráter de diálogo. Se as opiniões forem enunciadas, ouvidas, respeitadas e suspensas por todos os participantes do diálogo uma mente comum surgirá, uma vez que ela será o resultado de todos os conteúdos existentes no grupo, formando assim um conteúdo compartilhado por todos.

Outro aspecto é o fato de não haver no diálogo forças coercitivas, representadas por figuras de autoridade, pois assim cria-se uma assimetria nas relações, de forma que a liberdade deixa de ser igual entre os participantes e por diversos motivos certos assuntos podem não ser tratados, por medo da reação da autoridade. Além disso, não deve haver também uma agenda com objetivos a serem alcançados, pois uma vez definidos se está, na verdade, assumindo pressupostos, os quais não serão questionados ao longo do processo e, consequentemente, restringirão o diálogo (BOHM, 2005).

Por outro lado, Bohm (2005) afirma que

Podemos estabelecer propósitos de investigação, mas não estamos atrelados a um objetivo específico nem estabelecemos que o grupo inteiro deva ajustar-se indefinidamente a ele. [...] Nossa meta é, na realidade, comunicarnos coerente e verdadeiramente; se você quiser, pode chamar isso de objetivo. (p. 51).

Tendo em vista que nossa sociedade está habituada a trabalhar com autoridade e objetivos, Bohm (2005) sugere que a forma de se dialogar sem agenda ou líder é começar conversando sobre a ansiedade gerada por tais condições. Além disso, indica que pode existir um facilitador no diálogo, o qual deve ter o cuidado para se retirar da função assim que possível para deixar que o grupo ande sozinho.

Há também a importância da ausência de decisão no diálogo. "Num grupo de diálogo, não decidimos o que fazer a respeito de nada. Isso é crucial" (BOHM, 2005, p. 50). Ao agir dessa forma a liberdade estará instaurada. Outro ponto tratado pelo autor é o impulso da necessidade. Ele afirma que ao estabelecer algo como uma necessidade absoluta, aquilo que é 
inegociável, o conflito surge, pois há o encontro com outra necessidade absoluta de outro indivíduo ou grupos.

No diálogo, tanto do ponto de vista individual quanto do coletivo [...] os conflitos emergem em torno dessa noção de necessidade. Todas as discussões sérias, seja na família ou nos grupos de diálogo, se dão sobre pontos de vista diferentes a respeito do que é absolutamente necessário. (BOHM, 2005, p. 58, itálico do autor).

Assim, o conflito no diálogo surge por conta das necessidades absolutas, as quais podem impedir ou permitir a ocorrência daquele dependendo da postura adotada pelos participantes. Caso não permitam o questionamento de tal necessidade o diálogo estará impedido, por outro lado, se houver abertura para o questionamento ele ocorrerá, permitindo que ao fazê-lo se possa entrar num estado coerente de ideias.

Isaacs (1999) utiliza das ideias de David Kantor e William Lehr's (1975) ${ }^{11}$ para apontar outros dois aspectos importantes. O primeiro se refere à identificação das linguagens utilizadas pelas pessoas. Afirma que existem três tipos de linguagem: a linguagem do afeto, em que as pessoas falam o que sentem e investigam como os outros se sentem; a linguagem do significado, em que se busca compreender as ideias, os valores e as crenças naquilo que se conversa; e a linguagem da ação, na qual as pessoas que a falam querem saber como as coisas serão feitas. Se as pessoas estiverem numa conversa usando linguagens diferentes elas não se entenderão e por isso "entender qual linguagem você e os outros estão falando é vital para se engajar num diálogo genuíno.” (ISAACS, 1999, p. 211, tradução nossa ${ }^{12}$ )

"Pessoas falando a linguagem do sentimento tendem a ser desconsideradas pelas pessoas que falam a linguagem da ação e do poder. Pedindo para que estas pessoas [da ação] reflitam sobre o significado das coisas pode muitas vezes evocar uma reação de que você está sendo muito 'intelectual'. E fazer perguntas sobre como agir pode parecer prematuro para aqueles que falam as línguas do sentimento ou do significado." (ISAACS, 1999, p. 211, tradução $\left.\operatorname{nossa}^{13}\right)$.

O segundo aspecto é a identificação dos sistemas paradigmáticos adotados pelas pessoas. Afirma que existem três tipos de sistema: o aberto que funciona a partir da participação de todos, objetivando equilibrar as necessidades individuais e coletivas; o fechado que coloca a comunidade e as tradições históricas em primeiro lugar e os indivíduos

\footnotetext{
${ }^{11}$ KANTOR, D.; LEHR'S, W. In the Family. San Francisco: Jossey Bass, 1975.

12 "Understanding which language you and others are speaking is vital to engaging in genuine dialogue." (p. 211)

13 "People speaking the language of feeling tend to be discounted by people who speak the language of action and power. Asking such people to reflect about the meaning of things can often evoque the reaction that you are being too 'intelectual'. And asking questions about how to take action may feel premature to those communicating via the language of feeling or meaning." (p. 211)
} 
em segundo; e o randômico que às vezes funciona como um sistema aberto e às vezes como um sistema fechado (ISAACS, 1999).

Todos esses aspectos devem ser trabalhados no grupo de maneira processual, entendendo que a dinâmica de participação e envolvimento no diálogo leva tempo e, portanto, não é imediata. Nesse sentido, Isaacs $(1993 ; 1999)$ apresenta os estágios do diálogo (Figura 2), mostrando a evolução do container para acolher os diferentes momentos, uma vez que possui “[...] diferentes qualidades de pressão, energia e conhecimento.” (ISAACS, 1999, p. 255 , tradução nossa ${ }^{14}$ ) que emergem a partir do surgimento de crises.

Figura 2 - Estágios do diálogo

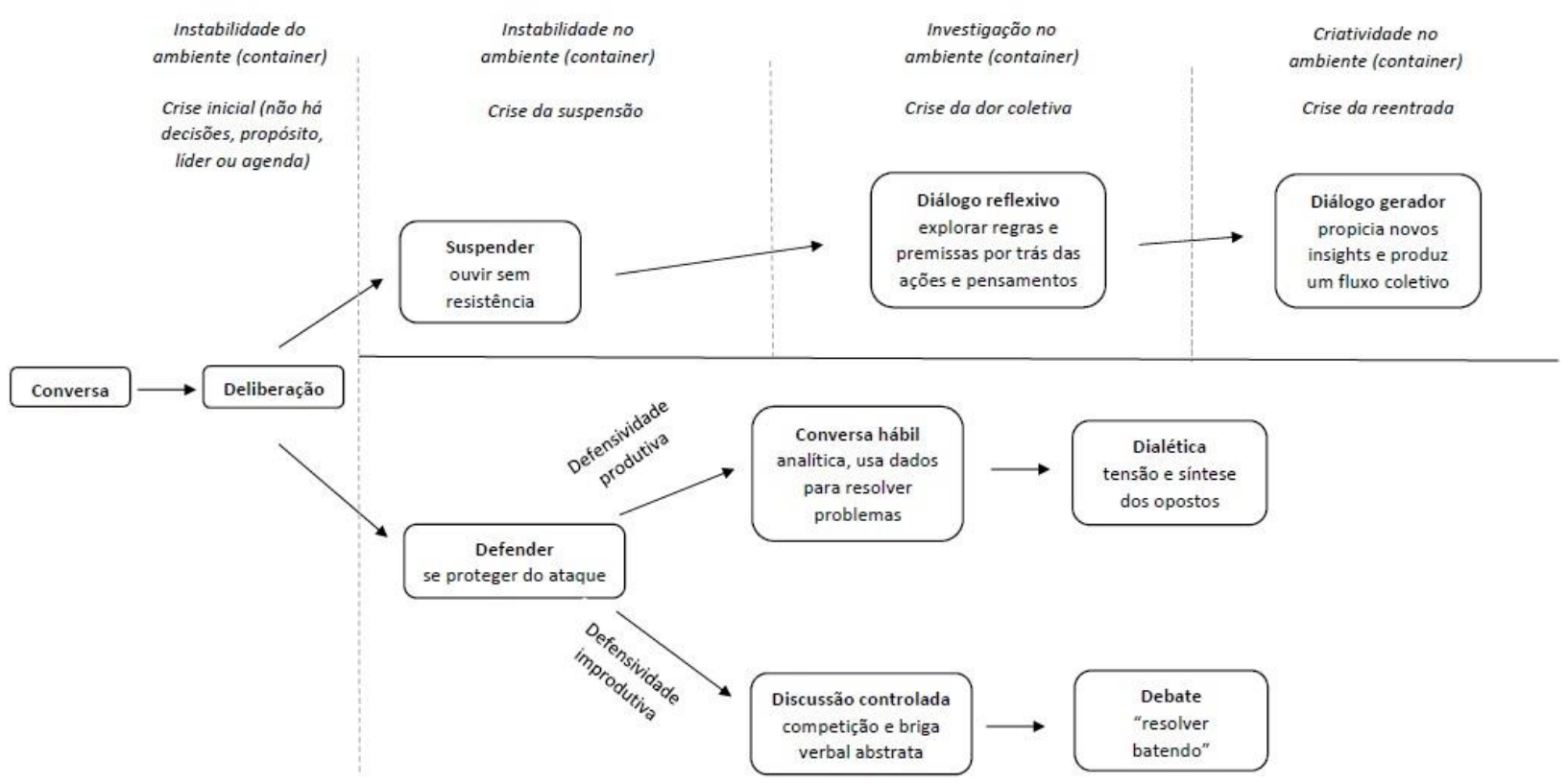

Fonte: Adaptado e traduzido de Isaacs (1993; 1999).

O processo dialógico se inicia com a escolha das pessoas em estabelecer um diálogo no grupo. Nos primeiros encontros os participantes adotam muitas regras de como se comportar, formas de pensar e agir que já tem familiaridade (pré-estabelecidas) e, portanto, que se sentem confortáveis. Assim, o container apresenta um clima de polidez, no qual as pessoas evitam contradizer umas às outras e entrar em qualquer tipo de conflito. O sentimento que prevalece é o medo, o qual "[...] parece reforçar o comportamento de seguir regras [préestabelecidas]." (ISAACS, 1999, p. 261, tradução nossa ${ }^{15}$ ).

Surge então a primeira crise, na qual as pessoas percebem a dificuldade de se alterar o modo habitual de conversar, expondo as opiniões para que os outros a observem sem

\footnotetext{
14 “[...] different qualities of pressure, energy, and knowledge.” (p. 255)

15 “[...] seems to reinforce rule-following behavior." (p. 261)
} 
julgamentos. E como tal postura não pode ser imposta, surge o sentimento de frustração entre os participantes (ISAACS, 1993).

Com o caminhar do processo, gradualmente as pessoas passam a dizer o que pensam e começa a surgir a fragmentação. Aqui as "[...] pessoas começam a batalhar para saber qual significado/ponto de vista tem mais poder." (ISAACS, 1999, p. 265, tradução nossa ${ }^{16}$ ), de forma que o sentimento que prevalece é o da raiva, caracterizado pelo pensamento de que “[...] não apenas nós temos posições diferentes, como claramente a sua é errada e a culpada pelas dificuldades que estamos enfrentando.” (ISAACS, 1999, p. 269, $\operatorname{tradução~nossa~}^{17}$ ). Isaacs (1999) afirma que muitas pessoas não conseguem passar desse estágio e acabam retornando para a polidez.

Instaurada essa polarização, entendida como algo positivo e esperado para a evolução do diálogo, as pessoas se deparam com uma importante escolha: defender ou suspender suas opiniões. Essa escolha acarreta uma nova crise, a da suspensão. Isso ocorre porque apesar da boa vontade em escolher suspender as opiniões, haverá momentos que o hábito de as defendêlas ressurgirá, e, portanto, os participantes ficam desorientados (ISAACS, 1993).

Se as pessoas se mantiverem no processo para além desse ponto a conversa começa a fluir de uma nova forma e o ambiente passa a ser de investigação, instaurando o diálogo reflexivo. As pessoas passam a investigar juntas os pensamentos e sentimentos, se tornando mais sensíveis à forma como a conversa afeta o grupo, de maneira que insights começam a surgir (ISAACS, 1993). Nesse estágio “As pessoas não sentem obrigação de exigir dos outros resposta ou concordância com suas perspectivas. [...] Embora eu possa ter uma posição, eu também sou uma pessoa com uma história, uma experiência particular" (ISAACS, 1999, p. 273, tradução nossa ${ }^{18}$ ).

Decorrente desse processo surge a crise da dor coletiva, caracterizada pela tomada de consciência das pessoas do impacto que o modo fragmentado do pensamento ocasionou em suas vidas. Essa dor surge da perda de crenças que sustentavam a existência de cada indivíduo de um lado e do exercício de trabalhar novas relações emocionais e cognitivas de outro. É nesse momento, proporcionado por esta crise, que é possível transformar as formas de

\footnotetext{
16 “[...] people begin to battle over whose meaning will have more power." (p. 265)

17 " "[...] "not only do we have different positions, but clearly yours is wrong and to blame for the difficulties we are facing."” (p. 269)

18 "People feel no obligation to require that others respond or agree with their perspective. [...] While I may have a position, I am also a person with a history, a particular background [...]" (p. 273)
} 
relação, uma vez que as maneiras de pensar e agir que impedem a união se tornam evidentes (ISAACS, 1993).

Se essa crise é superada um novo estágio de consciência se abre e instaura-se o diálogo gerador. Aqui a atmosfera se caracteriza por "[...] acomodar radicalmente diferentes pontos de vista sem exigir que nenhum deles mude [...]" (ISAACS, 1999, p. 280, tradução nossa ${ }^{19}$ ). Aqui as pessoas não reagem, elas ouvem e "[...] conectam o que está acontecendo na conversa com o que está acontecendo com elas próprias.” (ISAACS, 1999, p. 282, tradução nossa ${ }^{20}$ ), percebendo que compartilham um significado comum por terem explorado os pressupostos de todos os envolvidos no processo, instaurando um ambiente de criatividade (ISAACS, 1993).

Aqui temos a crise da reentrada. Depois de viver um processo desse há a crise de ter que voltar para as relações habituais, de voltar para o mundo. "Essa crise envolve aprender a deixar o significado do antigo mundo familiar mudar.” (ISAACS, 1999, p. 286, tradução $\left.\operatorname{nossa}^{21}\right)$.

A partir das ideias expostas acima, Bohm (2005) reforça:

O objetivo do diálogo não é analisar as coisas, ganhar discussões ou trocar opiniões. Seu propósito é suspender as opiniões e observá-las - ouvir os pontos de vista de todos, suspendê-los e a seguir perceber o que tudo isso significa. Se pudermos perceber o que significam todas as nossas opiniões compartilharemos um conteúdo comum, mesmo se não concordarmos completamente. (p. 65, itálico do autor).

Ao realizar esse exercício se estará estabelecendo uma "consciência participativa", na qual "tudo pode se mover entre nós." (BOHM, 2005, p. 65). Será possível compartilhar todos os pressupostos do grupo e ao perceber "[...] juntos o significado de todas as pressuposições, o conteúdo da consciência será essencialmente o mesmo.” (BOHM, 2005, p. 65). Para se chegar a essa consciência comum o autor sugere:

Precisamos compartilhar a consciência daquilo que realmente temos. Se as pessoas puderem compartilhar a frustração, e dividir entre si seus pressupostos diferentes e contraditórios, repartir sua raiva mútua e persistir no processo - se todo mundo ficar irritado junto e, em comum, observar esse fenômeno -, haverá uma consciência comum. (BOHM, 2005, p. 75, itálico do autor e negrito nosso).

Dessa forma, Bohm (2005) acredita que o diálogo é o caminho para a mudança do mundo, inclusive para os problemas ambientais. Afirmando que "temos de compartilhar nossa

\footnotetext{
19 “[...] accommodate radically different points of view without requiring any of them to change [...]" (p. 280)

20 " [...] by connecting what was happening in the conversation with what was happening in themselves." (p. 282)

21 "The crises here involves learning to let the meaning of this familiar old world change." (p. 286)
} 
consciência e nos capacitarmos para pensar juntos [...]. Se enfrentarmos o que ocorre num grupo de diálogo, compreenderemos o núcleo do que acontece no todo da sociedade.” (p. 47).

\subsubsection{Círculos de cultura (Paulo Freire)}

Paulo Freire (1921 - 1997), educador e pensador brasileiro, atual patrono da educação brasileira (BRASIL, 2012), apresenta o diálogo como caminho possível para a superação da relação opressor-oprimido, na qual o primeiro se caracteriza por ter força e poder, utilizados na dominação do segundo que, por sua vez, vive aderido a uma realidade mitificada. A superação dessa relação e a consequente libertação dos oprimidos se dá a partir da " [...] compreensão crítica da totalidade em que estão [...]" (FREIRE, 1981, p. 113), desvelando as condições histórico-culturais por meio dos círculos de cultura (FREIRE, 1981).

Antes de explorarmos esse caminho metodológico, o qual se constitui enquanto uma Ação Dialógica marcada pela co-laboração, união, organização e síntese cultural, é preciso entender os princípios dialógicos que o guiam. Freire (1981) fala de seis valores fundamentais do diálogo: amor, humildade, fé, confiança, esperança e pensar crítico.

Por ser o diálogo um encontro que permite a constante afirmação e desenvolvimento da humanização, assim como um ato de criação e recriação, constitui-se enquanto um ato amoroso (FREIRE, 1981). "Não há diálogo [...] se não há um profundo amor ao mundo e aos homens." (FREIRE, 1981, p. 93). Por ser um ato amoroso, o diálogo não pode se dar na relação de dominação. Acredito que esse amor se traduza na solidariedade, na empatia, na preocupação, no entender o Outro e, consequentemente, na não dominação e conquista do Outro. Se estamos numa situação opressora não é possível ocorrer o amor, e muito menos o diálogo.

Freire (1981) afirma que também não há diálogo sem humildade. Ao existir arrogância no encontro, ou seja, uns se sentindo superiores aos outros, não se torna possível a relação dialógica. "Como posso dialogar, se alieno a ignorância, isto é, se a vejo sempre no outro, nunca em mim?" (FREIRE, 1981, p. 95). Ao se achar mais sabedor do que o Outro se pensa ser o único contribuinte da conversa e não se considera o saber alheio. É evidente que essa postura é um obstáculo ao diálogo, já que não há abertura ao Outro e a novas ideias, apenas certezas individuais, de forma que a pronúncia passa a ser privilégio de uns poucos, o que caracteriza o cenário de dominação. "A auto-suficiência é incompatível com o diálogo. [...]. Neste lugar de encontro, não há ignorantes absolutos, nem sábios absolutos: há homens que, em comunhão, buscam saber mais.” (FREIRE, 1981, p. 95) 
Outra característica importante é a fé na humanidade. "Fé no seu poder de fazer e de refazer. De criar e recriar. Fé na sua vocação de Ser Mais, que não é privilégio de alguns eleitos, mas direito dos homens." (FREIRE, 1981, p. 95). E essa fé deve existir antes mesmo da ocorrência do diálogo. "O homem dialógico tem fé nos homens antes de encontrar-se frente a frente com eles." (FREIRE, 1981, p. 95)

Ao se estabelecer o amor, a humildade e a fé num encontro a confiança se faz consequência natural. Esta se instaura no momento do diálogo (FREIRE, 1981). "A confiança vai fazendo os sujeitos dialógicos cada vez mais companheiros na pronúncia do mundo. Se falha esta confiança, é que falharam as condições discutidas anteriormente." (FREIRE, 1981, p. 96, itálico do autor). Ela se traduz no testemunho que um indivíduo dá aos outros participantes do encontro dialógico sobre seus reais pensamentos e intenções (FREIRE, 1981).

O diálogo também deve vir acompanhado da esperança. Homens e mulheres reunidos num encontro para pronunciar o mundo, mediatizados por ele, para sua conquista, não podem fazê-lo sem ter um objetivo, sem nada esperar (FREIRE, 1981). "Se os sujeitos do diálogo nada esperam do seu quefazer já não pode haver diálogo. O seu encontro é vazio e estéril. É burocrático e fastidioso.” (FREIRE, 1981, p. 97).

Por último, não é possível o diálogo sem um pensar crítico, o qual permite o desvelamento da realidade entendendo-a enquanto processo histórico e que, por isto mesmo, pode ser alterada, transformada (FREIRE, 1981).

Baseado nesses princípios do diálogo, Freire (1981) elaborou a Teoria da Ação Dialógica, caracterizada por quatro elementos: a co-laboração; a união; a organização; a síntese cultural. A co-laboração se caracteriza pelo encontro de homens e mulheres, para juntos, transformar a realidade. Esta é problematizada, e não mitificada. Esse trabalho conjunto se dá por meio da comunicação, uma vez que "o diálogo, que é sempre comunicação, funda a colaboração." (FREIRE, 1981, p. 197). Seu elemento oposto, característico da Ação Antidialógica, é a conquista. Esta é marcada por uma relação de dominação de um indivíduo pelo outro, na qual o dominado se torna um objeto, tendo sua humanidade roubada. O objetivo dessa conquista é manter a realidade tal qual ela se apresenta, ou seja, o cenário no qual os indivíduos conquistadores, opressores, possuem o poder. E para manter essa realidade, se utilizam dos mitos, os quais permitem a criação de um mundo falso, a-histórico, por meio dos "comunicados" que são aceitos sem reflexão pelos conquistados, uma vez que se encontram alienados da realidade (FREIRE, 1981). 
O segundo elemento da Teoria da Ação Dialógica é a união, a qual busca aproximar os indivíduos. Para sua ocorrência é essencial que se desmitifique a realidade, pois assim permite que “[...] reconhecendo o porque e o como de sua 'aderência' [à realidade], exerçam um ato de adesão à práxis verdadeira de transformação da realidade injusta.” (FREIRE, 1981, p. 205, itálico do autor). Seu elemento oposto é a divisão dos conquistados, caracterizando-se pelo constante exercício de impedir que a maioria dominada se una e se organize, haja vista que ao fazê-lo contestarão a organização social vigente e, assim, os conquistadores terão seu poder ameaçado. Para impedir tal movimento de mobilização são utilizados diversos métodos, desde os mais sutis aos mais agressivos. Um exemplo de método sutil se caracteriza pela visão focalista, parcial da realidade, a qual impede os indivíduos de se apropriarem da totalidade e, assim, entender e se apoderar do contexto em que vivem. Por outro lado, um exemplo de método agressivo é o uso de força física para conter as pessoas em situação de mobilização (FREIRE, 1981).

Outro elemento da Ação Dialógica é a organização das massas. Para explicá-la se faz necessário entender o importante papel da liderança revolucionária. Esta se caracteriza pela postura dialógica e, como tal, possui os elementos de tal postura. Portanto, a liderança para co-laborar com as massas deve estar em comunhão com elas, estabelecer uma relação de confiança para juntas desvelar a realidade, desmitificando-a, e assim transformá-la. Seu papel na organização das massas é o de dar o testemunho de que a busca por libertação é um objetivo comum, ou seja, a libertação é o motivo pelo qual a organização se dá. No entanto, não pode dar seu testemunho de forma impositiva, mas deve fazê-lo com o povo (FREIRE, 1981). Seu elemento oposto é a manipulação que objetiva impedir que os conquistados desenvolvam o pensamento crítico. E para isso utilizam da imaturidade política e de mitos para convencer as massas que os objetivos dos conquistadores são válidos e devem ser defendidos, já que eles se apresentam, falsamente, como os protetores da sociedade. Essa estratégia é muito forte, uma vez que o conquistado, hospedando dentro de si o conquistador, passa a acreditar que a realidade que se apresenta é imutável e que não deve ser contestada (FREIRE, 1981).

O último elemento da Teoria da Ação Dialógica é a síntese cultural. Nesta não há imposição de uma visão de mundo, mas sim o respeito às diferentes formas de ver a realidade. Aqui o objetivo é incidir sobre esta a partir dessas diferentes formas de vê-la. Ou seja, é a ação pela qual homens e mulheres podem se libertar da alienação, a partir do entendimento histórico de sua condição. A liderança aqui não impõe seus valores, mas se junta ao povo para 
que unidos e organizados possam se libertar (FREIRE, 1981). "A síntese cultural não nega as diferenças entre uma visão e outra, pelo contrário, se funda nelas. O que ela nega é a invasão de uma pela outra. O que ela afirma é o indiscutível aporte que uma dá à outra." (FREIRE, 1981, p. 215). Nesse sentido, há uma estreita relação com o diálogo gerador proposto por Isaacs $(1993 ; 1999)$, no qual não se tenta convencer o Outro ou impor ideias, reconhecendo que cada um tem uma história diferente. Seu elemento oposto é a invasão cultural, caracterizada pela imposição da visão de mundo dos conquistadores aos conquistados. Para que essa imposição seja "aceita" pela massa se faz necessário uma condição básica, o convencimento de que os conquistados são inferiores aos conquistadores (FREIRE, 1981). Assim,

A invasão cultural, que serve à conquista e à manutenção da opressão, implica na visão focal da realidade, na percepção desta como estática, na superposição de uma visão do mundo na outra. Na 'superioridade' do invasor. Na 'inferioridade' do invadido. Na imposição de critérios. Na posse do invadido. No medo de perdê-lo. (FREIRE, 1981, p. 188).

Considerando o exposto acima, Freire (1981) apresenta os círculos de cultura como o processo pelo qual os participantes agem dialogicamente, desvelando a realidade que vivem, identificando e entendendo suas contradições fundamentais como construções históricoculturais que podem ser transformadas.

Da mesma forma que os grupos de diálogo de Bohm e Isaacs possuem um procedimento metodológico central, a suspensão dos pressupostos, os círculos de cultura apresentam o exercício de codificação e descodificação, sendo a primeira a representação de uma situação existencial e a segunda a análise crítica de tal situação. Dessa forma, a codificação é a representação do todo e a descodificação "[...] implica numa ida das partes ao todo e numa volta deste às partes, que implica num reconhecimento do sujeito no objeto (a situação existencial concreta) e do objeto como situação em que está o sujeito.” (FREIRE, 1981, p. 114).

O processo de descodificação é detalhado por Freire (1983), constituindo-se por quatro momentos. O primeiro se caracteriza pela observação/“ad-miração” da realidade codificada com o intuito de apreende-la como um todo. O segundo pela descrição de tal realidade, cindindo a totalidade "ad-mirada" em partes a serem analisadas. Em seguida, no terceiro momento, há a "re-admiração" das "ad-mirações" anteriores sobre a realidade codificada, vista novamente em sua totalidade, uma vez que se busca identificar as relações existentes entre os elementos desta, de forma que ao fazê-lo as pessoas passam a questionar as opiniões 
construídas ao longo de suas vidas sobre a situação existencial representada, desenvolvendo, assim, uma criticidade que não mais aceita explicações focalistas da realidade, ou seja, sua compreensão fragmentada. A partir disso, emerge o quarto momento caracterizado pelo aprofundamento e realização da análise crítica do contexto que se vive.

Os círculos de cultura são constituídos por 3 fases. A primeira se inicia com a visita dos investigadores (ou propositores do processo dialógico) ao local escolhido para o trabalho, apresentando a proposta para as pessoas que ali vivem e convidando-as para participar do processo de investigação temática. Depois de formada a equipe de investigação com pessoas interessadas da comunidade são realizadas visitas ao local, que se apresenta como uma “codificação viva", a partir da qual os investigadores realizarão o exercício de descodificação, anotando em seus diários de campo tudo o que chama a atenção: modos de relacionamento das pessoas entre si e com o ambiente, os costumes, a fala e o que mais for relevante. Essas visitas devem ocorrer em diferentes horários e dias para que os investigadores possam ter uma compreensão profunda das diferentes dinâmicas daquela realidade (FREIRE, 1981).

Findadas as primeiras visitas, constroem-se relatórios com as diversas percepções dos investigadores que devem ser dialogados entre os mesmos em seminário. O objetivo desse diálogo é permitir aos participantes que percebam suas percepções a partir da escuta das percepções dos outros, ou seja, que "re-admirem" "[...] sua admiração anterior no relato da ‘ad-miração' dos demais" (FREIRE, 1981, p. 124). O processo de "re-admirar” a admiração por meio da "ad-miração" do Outro permite retotalizar a realidade cindida, que se apresentará de uma nova forma, a qual exigirá nova descodificação e seminário avaliativo para "readmirar" o que se admirou. "Quanto mais cindem o todo e o re-totalizam na re-admiração que fazem de sua ad-miração, mais vão aproximando-se dos núcleos centrais das contradições principais e secundárias em que estão envolvidos os indivíduos da área.” (FREIRE, 1981, p. 125)

A partir desse exercício os investigadores conseguem identificar as principais contradições existentes naquela realidade (que envolvem as "situações-limites"). Do conjunto de contradições identificadas serão escolhidas algumas para se formar as codificações "[...] que vão servir à investigação temática.” (FREIRE, 1981, p. 127) junto às pessoas do local de trabalho, com o propósito de identificar a percepção que possuem sobre tais contradições, caracterizando a segunda fase do processo. Essas codificações podem ser representadas por pinturas, fotos, dramatizações, áudio, vídeos ou até mesmo pela fala. Importante ressaltar que 
é preciso que os sujeitos reconheçam a situação codificada (realidade conhecida) e que as codificações não sejam tão explícitas e nem tão enigmáticas (FREIRE, 1981).

Preparadas as codificações se inicia a terceira fase. Nesta os investigadores voltam à área para dialogar nos "círculos de investigação temática”, nos quais “[...] os participantes [...] vão extrojetando, pela força catártica da metodologia, uma série de sentimentos, de opiniões, de si, do mundo e dos outros, que possivelmente não extrojetariam em circunstâncias diferentes.” (FREIRE, 1981, p. 132-133). Freire diz que cada círculo de investigação temática deve ter um máximo de 20 pessoas, “[...] existindo tantos círculos quantos a soma de seus participantes atinja a da população da área ou da subárea em estudo.” (FREIRE, 1981, p. 132).

Depois de realizadas as descodificações nos círculos de investigação temática, os investigadores analisam os resultados coletados, os temas geradores que emergiram. Destes é feita a delimitação temática da qual se desprenderá um projeto de "redução" temática com o objetivo de reduzir um ou mais temas em seus núcleos fundamentais. Além disso, "neste esforço de 'redução' da temática significativa, a equipe reconhecerá a necessidade de colocar alguns temas fundamentais que, não obstante, não foram sugeridos pelo povo, quando da investigação.” (FREIRE, 1981, p. 136).

Findada a redução é realizada uma nova codificação da realidade, compondo o conteúdo programático do processo educador a ser utilizado junto às pessoas da área de trabalho nos chamados círculos de cultura. Nestes as pessoas se constituem enquanto sujeitos que desvelam a totalidade em que estão inseridos por meio também da codificação e descodificação dialógica (FREIRE, 1981).

Por fim, Freire (1981) afirma que caso não seja viável realizar todo o processo de investigação temática proposto, é possível

Com um mínimo de conhecimento da realidade [...] escolher alguns temas básicos que funcionariam como 'codificações da investigação'. Começariam assim o plano com temas introdutórios ao mesmo tempo em que iniciariam a investigação temática para o desdobramento do programa, a partir destes temas. (p. 139).

\subsubsection{Síntese dos caminhos metodológicos e perguntas-indicadoras}

A relação entre as ideias dos autores do diálogo, entendendo seus diferentes contextos e perspectivas, constitui-se num importante exercício para a emergência de novas compreensões sobre o assunto em questão. Permite, como sugerem Aragão e Navarro (2004), a descoberta de "[...] ângulos que continuam ocultos à espera de um dia serem 
descobertos/acordados/construídos por outros olhares, que poderão vir de lugares/tempos distantes." (p. 115).

Stewart, Zediker e Black (2004), realizando esse exercício de síntese, enunciaram que Buber, Bohm e Freire escreveram sobre o diálogo a partir de bases experienciais e hábitos mentais que apresentam mais similaridades do que diferenças, mesmo que o tenham feito em tempos e culturas diferentes. As bases experienciais se constituem pelos eventos vividos por esses autores ao longo de suas trajetórias históricas, contribuindo para a formulação de suas ideias. De acordo com os autores

David Bohm "teve uma infância difícil” (Pruyn, 2000)22, não somente porque ele era um judeu que vivia nos Estados Unidos, mas também por causa da doença mental de sua mãe. Depois de um começo promissor como intelectual (Caltech, Berkeley, uma nomeação em física em Princeton), foi levado ao exílio pelo macarthismo e, apesar de sua amizade com Einstein, foi ignorado ou ridicularizado por muitos colegas por seu misticismo. Os pais de Buber se divorciaram, sua precocidade o fez "estranho" quando criança, ele foi expulso de sua casa austríaca pelos nazistas e viveu em contínuo conflito com líderes xenófobos e anti-árabes em Israel (Friedman, $1981^{23}, 1983 b^{24}, 1983 c^{25}$ Gordon, $1988^{26}$ ). Quanto a Freire, a quebra do mercado de 1929 significou que "a precária estabilidade da família de classe média de Freire cedeu e ele se viu compartilhando a situação dos 'miseráveis da terra'. Isso teve uma influência profunda em sua vida quando ele conheceu as angustiantes dores da fome" (Shaull, 1990, p. 10) ${ }^{27}$. Freire dedicou sua vida a uma filosofia da educação que respondia à crise existencial que ele experimentou e viu diante dele. (STEWART; ZEDIKER; BLACK, 2004, p. 30, tradução nossa ${ }^{28}$ ).

Os hábitos mentais, por sua vez, caracterizam-se pela forma de pensar tais eventos. Há dois hábitos mentais marcantes nos autores do diálogo. O primeiro é o holismo, a busca por compreender a realidade considerando sua totalidade, e o segundo é a tensionalidade, a qual

22 PRUYN, F. Infinite potencial: The life and times of David Bohm. 2000. Disponível em: http://www.theosophy-nw.org/thesnw/science/sc-pruyn.htm

${ }^{23}$ FRIEDMAN, M. Martin Buber's life and work: The early years 1878-1923. New York: E. P. Dutton, 1981.

${ }^{24}$ FRIEDMAN, M. Martin Buber's life and work: The later years 1945-1965. New York: E. P. Dutton, 1983b.

${ }^{25}$ FRIEDMAN, M. Martin Buber's life and work: The middle years 1923-1945. New York: E. P. Dutton, $1983 \mathrm{c}$.

${ }^{26}$ GORDON, H. The other Martin Buber: Recollections of his contemporaries. Columbus: Ohio University Press, 1988.

${ }^{27}$ SHAULL, R. Foreword. In: Paulo Freire, Pedagogy of the oppressed. New York: Continuum, 1990.

${ }^{28}$ David Bohm "experienced a difficult childhood" (Pruyn, 2000) not only because he was a Jew living in America but also because of his mother's mental illness. After a promising start as an intellectual (Caltech, Berkeley, an appointment in physics at Princeton), he was driven into exile by McCarthyism, and despite his friendship with Einstein, was ignored or ridiculed by many collegues for his mysticism. Buber's parents were divorced, his precociousness made him "odd" as a child, he was driven from his Austrian home by the Nazis, and he lived in continuous conflict with xenophobic and anti-Arab leaders in Israel (Friedman, 1981, 1983b, 1983c; Gordon, 1988). As for Freire, the 1929 market crash meant that "the precarious stability of Freire's middle-class family gave way and he found himself sharing the plight of 'the wretched of the earth'. This had a profound influence on his life as he came to know the gnawing pangs of hunger" (Shaull, 1990, p. 10). Freire dedicated his life to a philosophy of education that was responsive to the existential crisis he experienced and saw before him. (p. 30) 
se constitui enquanto uma característica do pensamento holístico, buscando entender a realidade de forma dinâmica e dialética (STEWART; ZEDIKER; BLACK, 2004).

Em sua tese de doutorado, Navarro (2005) propõe um caminho dialógico a partir de uma síntese das ideias de David Bohm, Paulo Freire e Mikhail Bakhtin sobre o diálogo, partindo do pressuposto de que esses autores compartilham a importância de se ter “[...] ciência da dialogia como fundamento da vida.” (p. 36), mas que apresentam caminhos diferentes para alcançá-la.

Sua proposta dialógica se inicia com a realização da suspensão dos pressupostos (perspectiva bohmiana), o qual permite, por sua vez, o processo de conscientização a respeito da construção histórico-cultural que se vive (perspectiva freireana), culminando, por fim, no aprendizado de que é na relação com o outro que está o sentido da existência (perspectiva bakhtiniana) (NAVARRO, 2005).

Andrade (2013), por sua vez, utiliza em sua tese diversos autores do diálogo para construir seu entendimento sobre o mesmo. Dentre as reflexões tecidas propõe uma síntese entre as ideias de David Bohm, William Isaacs e Paulo Freire sobre a dimensão do agir em busca de transformações na realidade, afirmando que

[...] a suspensão de pressupostos de Bohm [...] [pode] promover importantes mudanças nos sentidos que as pessoas atribuem ao mundo (BOHM, 1999) ${ }^{29}$, repercutindo, consequentemente, em suas ações. Assim, como coloca Isaacs $(1999 a)^{30}$, a prática do diálogo não visa apenas à conversa, mas também a ação, e especificamente a ação coletiva. O diálogo é, portanto, uma práxis, em que o encontro dos homens promove a transformação do mundo, 'um caminho pelo qual os homens ganham significação enquanto homens' [...] (FREIRE, $1987^{31}$, p. 45 apud ANDRADE, 2013, p. 62-63).

Tendo em vista todo o exposto acima, buscou-se aqui realizar também um exercício de síntese $^{32}$ a partir das ideias de David Bohm, William Isaacs e Paulo Freire por se entender que a união dos princípios e características presentes nos grupos de diálogo e nos círculos de cultura podem potencializar a caminhada pela espiral dialógica. Assim, os elementos presentes nos caminhos propostos pelos autores foram organizados em três categorias de análise, cada qual composta por um conjunto de perguntas-indicadoras.

A primeira, intitulada “Aspectos Externos", é composta pelos elementos referentes à estrutura do encontro: sua frequência, o número de pessoas envolvidas, a disposição das

\footnotetext{
${ }^{29}$ BOHM, D. Unfolding meaning: a weekend of dialogue. London and New York: Routledge, 1999.

${ }^{30}$ ISAACS, W. Dialogue and the art of thinking together: a pioneering approach to communicating in business and in life. New York: Doubleday, 1999a.

${ }^{31}$ FREIRE, P. Pedagogia do oprimido. 17 ed. Rio de Janeiro: Paz e Terra, 1987.

${ }^{32}$ Essa síntese foi incrementada nas "Considerações Finais" da presente dissertação.
} 
mesmas e o local do encontro. A segunda categoria, intitulada "Aspectos Internos", traz os elementos ligados às posturas de cada indivíduo: a deliberação pelo diálogo, ouvir e ser ouvido, enfrentar conflitos, identificar e suspender pressupostos, desvelar aspectos culturais e demonstrar amor, humildade, fé, confiança, esperança e pensamento crítico. Por fim, a terceira categoria, intitulada "Ação Dialógica", traz os elementos dos círculos de cultura: a apresentação do projeto com o propósito de convidar interessados para realizar a investigação temática, a realização dos círculos de investigação temática e a realização dos círculos de cultura. As perguntas-indicadoras referentes a cada categoria estão descritas no Quadro 1 a seguir. 
Quadro 1 - Indicadores do diálogo

\begin{tabular}{|c|c|}
\hline ESPIRAL DIALÓGICA & PERGUNTAS-INDICADORAS \\
\hline \multirow{4}{*}{ Aspectos Externos } & Qual foi a frequência dos encontros? \\
\hline & Qual era o número de pessoas envolvidas nos encontros? \\
\hline & $\begin{array}{l}\text { Qual era a disposição das pessoas no encontro (em círculo, em } \\
\text { fileira etc.)? }\end{array}$ \\
\hline & $\begin{array}{l}\text { Os locais dos encontros possuíam uma boa acústica e } \\
\text { propiciavam que os atores estivessem focados no mesmo? }\end{array}$ \\
\hline \multirow{6}{*}{ Aspectos Internos } & Houve deliberação pelo diálogo? \\
\hline & $\begin{array}{l}\text { Todos podiam se expressar, respeitando e ouvindo, por sua vez, } \\
\text { os outros? }\end{array}$ \\
\hline & Permitiu-se a emergência da polarização por meio dos conflitos? \\
\hline & $\begin{array}{c}\text { Houve a exposição dos pressupostos por parte dos dois conjuntos } \\
\text { de atores olhando-os de forma suspensa? Se não, pelo menos } \\
\text { cada conjunto de atores reconhecia os pressupostos do outro } \\
\text { grupo? }\end{array}$ \\
\hline & $\begin{array}{l}\text { Há indícios de que o processo vivido permitiu o desvelamento de } \\
\text { aspectos culturais? }\end{array}$ \\
\hline & $\begin{array}{l}\text { Há indícios da presença do amor, da humildade, da fé, da } \\
\text { confiança, da esperança e do pensar crítico no processo vivido? }\end{array}$ \\
\hline \multirow{6}{*}{ Ação dialógica } & $\begin{array}{c}\begin{array}{c}\text { A intenção de projeto foi apresentada para a comunidade com o } \\
\text { propósito de convidar interessados para realizar a investigação } \\
\text { temática? }\end{array} \\
\end{array}$ \\
\hline & $\begin{array}{l}\text { Há indícios de que houve uma investigação temática por meio } \\
\text { da codificação e descodificação junto com os pescadores? }\end{array}$ \\
\hline & $\begin{array}{l}\text { Foram proporcionados momentos para re-admirar as ad- } \\
\text { mirações? }\end{array}$ \\
\hline & $\begin{array}{l}\text { Foram feitos círculos de investigação temática com os } \\
\text { pescadores? Se sim, se desdobraram nos círculos de cultura? }\end{array}$ \\
\hline & $\begin{array}{l}\text { Caso o processo completo não tenha ocorrido, pelo menos } \\
\text { realizou-se a perspectiva reduzida proposta por Freire? }\end{array}$ \\
\hline & $\begin{array}{l}\text { Quais foram as tomadas de decisão conjuntas entre os atores } \\
\text { que se desdobraram em um trabalho colaborativo, organizado e } \\
\text { que acolheu as diferenças, a partir do desvelamento da realidade } \\
\text { por meio dos temas geradores? }\end{array}$ \\
\hline
\end{tabular}

Fonte: Os dados para compor esse quadro foram retirados de Freire $(1981 ; 1983)$, Isaacs $(1993 ; 1999)$, Bohm (2005) e Andrade (2013).

A partir disso, destaca-se aqui a importância de não se crer ingenuamente que um grupo de pessoas que se auto intitule enquanto um grupo de diálogo (BOHM, 2005; ISAACS, 1999) ou um círculo de cultura (FREIRE, 1981) realize de fato os exercícios de suspensão dos 
pressupostos e de codificação e descodificação, respectivamente. É possível que ao tentar realizar tais exercícios o grupo falhe exatamente por não estar habituado a dialogar, por ter em si os princípios do paradigma mecanicista fragmentador.

Num processo educador ambientalista tal situação ainda é muito recorrente pelo grande desejo de mudança que habita em cada educadora e educador ambiental. Muitas vezes, esse desejo acaba se concretizando por meio de ações antidialógicas, haja vista o caráter de urgência que acompanha tais iniciativas. Portanto, é muito importante o cuidado com as armadilhas do paradigma vigente que nos aprisionam e nos impedem de superá-lo, como o imediatismo, o individualismo, a competição e outros.

Assim, o que se propõe aqui é uma interpretação unificada de dois caminhos possíveis para a existência dialógica a serem utilizados na vida cotidiana e, em particular, pelas educadoras(es) ambientais, às(aos) quais fica o convite para experimentarem tais procedimentos em suas práticas. E para as(os) educadoras(es) ambientais que tem em Paulo Freire uma de suas referências teóricas, implementando em suas práticas o exercício da codificação e descodificação, fica o convite para se aventurarem com o exercício da suspensão dos pressupostos. 


\section{ORGANIZAÇÕES NÃO GOVERNAMENTAIS}

Neste capítulo serão apresentados a definição de organizações não governamentais (ONGs), seus aspectos históricos e contradições, bem como as ONGs ambientalistas e a educação ambiental que adotam em seus discursos e práticas, com o intuito de compreender como o diálogo se fez/faz, ou não, presente na constituição histórica da identidade desse ator social.

\subsection{Definição}

A Associação Brasileira de Organizações Não Governamentais (ABONG) (2016) define em seu Estatuto Social, capitulo I, artigo $2^{\circ}$

[...] são consideradas Organizações Não Governamentais - ONGs, as entidades que, juridicamente constituídas sob a forma de fundação ou associação, todas sem fins lucrativos, notadamente autônomas e pluralistas, tenham compromisso com a construção de uma sociedade democrática, participativa e com o fortalecimento dos movimentos sociais de caráter democrático, condições estas, atestadas pelas suas trajetórias institucionais e pelos termos dos seus estatutos. (p. 1).

Borrelli (2008) define ONGs como “organizações formais, privadas, porém com fins públicos, não lucrativos, auto-governadas e com participação de parte de seus membros como voluntários." (p. 14). Landim (2002), por sua vez, afirma que a grosso modo as ONGs podem ser definidas como

[...] organizações com razoável grau de independência em sua gestão e funcionamento, criadas voluntariamente, sem pretender caráter representativo e sem ter como móvel o lucro material, dedicadas a atividades ligadas a questões sociais, pretendendo a institucionalização, a qualificação do trabalho e a profissionalização de seus agentes, tendo a fórmula «projeto » como mediação para suas atividades, onde as relações internacionais incluindo redes políticas e sociais e recursos financeiros - estão particularmente presentes. Organizações nas quais, finalmente, o ideário dos direitos e da cidadania é marca de peso, permeando e politizando atividades variadas (muitas vezes formalmente as mesmas que caracterizam o campo dito assistencial). (p. 238).

Vale destacar que o fato da identidade dessas organizações ser marcada pelo negativo, o não ser governamental, apesar de carecer de um sentido propositivo, permite a constituição de uma identidade de fronteira, na qual se pode incorporar uma série de conflitos e disputas. Por outro lado, traz esse ambiente de ambiguidade no qual diferentes concepções surgem em torno das ONGs (STEIL; CARVALHO, 2007).

Tal situação faz com que a definição de Organizações Não Governamentais não compreenda um consenso entre as diversas organizações que assim se intitulam 
(MACHADO, 2012), de forma que a expressão se caracteriza pela polissemia, “[...] num campo que se presta a várias apropriações ideológicas ou discursivas, possibilitando usos diversificados por diferentes atores [...]" (LANDIM, 2002, p. 216). Assim, para entender a constituição dessa grande diversidade será apresentado a seguir o histórico dessas organizações em âmbito internacional e nacional.

\subsection{Aspectos históricos e contradições}

\subsubsection{Contexto histórico internacional}

O surgimento das ONGs no contexto internacional se dá no Pós Segunda Guerra Mundial com o objetivo de criar espaços institucionalizados promotores de paz e cooperação econômica para levar aos países destruídos pela guerra e aos países do terceiro mundo a democracia e o capitalismo (STEIL; CARVALHO, 2007).

A primeira vez que a denominação ONG aparece no mundo é no final dos anos 1940 em documentos da Organização das Nações Unidas (ONU), “[...] tendo como pano de fundo a ideologia e a prática social denominada desenvolvimento de comunidades, que pautaram as relações políticas de cooperação e dominação dos países ricos sobre os países pobres no Ocidente capitalista.” (STEIL; CARVALHO, 2007, p. 172, itálico dos autores). Nasceram, portanto, num contexto de dominação, em meio à política desenvolvimentista dos Estados Unidos com uma perspectiva filantrópica (STEIL; CARVALHO, 2007).

Na década de 1970 surge uma segunda geração de ONGs ligadas ao desenvolvimento social, cidadania e sociedade civil a partir das conferências promovidas pela ONU, em especial a Conferência sobre o Meio Ambiente realizada em Estocolmo, influenciada pelas políticas europeias para o desenvolvimento ligadas a fundos governamentais e privados, estes provenientes principalmente das igrejas cristãs (STEIL; CARVALHO, 2007).

No contexto da América Latina esses fundos europeus foram destinados aos centros e institutos de educação que se constituíam enquanto pontos de resistência aos regimes militares instituídos com o propósito de formar lideranças e apoiar os movimentos sociais e sindicatos. Nas décadas de 1980 e 1990, com o fim das ditaduras militares e o estabelecimento da democracia, os centros e institutos passam a se definir como ONGs (STEIL; CARVALHO, 2007).

Porém, o contexto vigente se caracterizava pelos princípios neoliberais de Estado mínimo, fortemente influenciado pela globalização e pelo aporte financeiro vindo dos 
organismos multilaterais ligados ao capitalismo, de forma que as ONGs passam a atuar ora na mediação dos movimentos sociais, ora na execução de políticas públicas não atendidas pelo Estado. Nesse sentido, começam a ser reguladas por este e, assim, ocorre uma mudança na ideia de representação até então exercida pelas ONGs. A princípio elas estavam intimamente ligadas às bases com as quais trabalhavam, passando agora a identificar os problemas sociais de maneira mais distanciada daquelas (STEIL; CARVALHO, 2007).

Nos anos 2000 surge uma nova fase, a qual se contrapõe à perspectiva mercadológica. Os Fóruns Sociais Mundiais (FSMs) “[...] inscrevem as faces de tantos outros mundos possíveis e dos atores sociais que vêm sustentando um espaço de alteridade política e societária." (STEIL; CARVALHO, 2007, p. 177). Nesse contexto, as ONGs ganham visibilidade por estarem inseridas nos Fóruns, porém, não conseguiram chegar ainda a um consenso sobre uma agenda comum de ações em prol das transformações almejadas (STEIL; CARVALHO, 2007).

\subsubsection{Contexto brasileiro}

No Brasil as ONGs surgem em meio ao período da ditadura militar que acabou por extinguir partidos, sindicatos, entidades de bairro e as experiências educacionais realizadas com comunidades tradicionais. Em resposta a tais investidas surgem grupos de base, de caráter político-religioso, que atuam clandestinamente em prol das demandas populares. Inicialmente tratavam das demandas dos trabalhadores brasileiros e do consumo de bens de serviços se expandindo posteriormente para outras questões como gênero, etnia, opção sexual, meio ambiente e outros temas (STEIL; CARVALHO, 2007).

Esses grupos de base se organizaram formando os centros de educação e conscientização e os institutos de estudos e pesquisa, ambos representando a origem das ONGs. Assim como ocorreu na América Latina, no momento de abertura democrática muitos desses centros passaram a se autodenominar como ONG (STEIL; CARVALHO, 2007).

De acordo com Oliveira e Haddad (2001) o processo educador promovido pelos centros de educação era o de "[...] ampliar o nível de compreensão que a população pobre tinha das suas condições de vida, discutindo as suas causas, visando uma atuação crítica na sociedade.” (p. 76, negrito nosso). Para isso, buscava-se aliar o desvelamento da realidade com intervenções na mesma para superar os problemas identificados, atuando em prol da transformação social. 
Dessa forma, é possível perceber a grande influência das ideias de Paulo Freire nesses espaços, nos quais os participantes, entendidos como sujeitos do processo, realizavam o exercício da práxis, por meio do diálogo e com uma intencionalidade política de transformação da realidade (FREIRE, 1981; 1983).

Um grande desafio desses centros era a necessidade de trabalhar na clandestinidade, tendo em vista a censura e a repressão do regime militar. Além disso, era um processo educador que ocorria desconectado das instituições formais de educação, uma vez que se encontravam fortemente dominadas pela ideologia vigente (OLIVEIRA; HADDAD, 2001).

Uma característica importante desses centros era a falta de articulação existente entre eles, o que dificultava a constituição institucional por meio de uma base comum. Além disso, havia uma pretensão de que o movimento realizado pelos centros era transitório à medida que as lideranças dos movimentos sociais pudessem assumir a luta (STEIL; CARVALHO, 2007).

Na década de 1980 há uma explosão dos movimentos sociais incluindo novos temas para além dos interesses de classe: “[...] feminismo, ambientalismo, questões étnicas, tecnologias agroecológicas, informatização, mídia alternativa, etc.” (STEIL; CARVALHO, 2007, p. 181). Essa diversidade temática influencia fortemente a constituição das ONGs que se formam, orientando os trabalhos a serem desenvolvidos de acordo com a temática escolhida, ampliando assim o rol de atuação. A constituição das ONGs nesse período é fruto da crescente autonomia, da profissionalização do trabalho desenvolvido, do processo de democratização da sociedade civil e do reconhecimento e interesse das agências financiadoras internacionais. (STEIL; CARVALHO, 2007; OLIVEIRA; HADDAD, 2001).

Entrando na década de 1990, devido à crise vivida pelo país, o aumento das dívidas interna e externa e a dificuldade de manter a produção e exportação de bens de acordo com os preceitos capitalistas, o capital financeiro passa a predominar sobre os Estados, pela ideologia neoliberal, restringindo o desenvolvimento do país (STEIL; CARVALHO, 2007).

É nesse contexto que emerge uma importante crítica às ONGs: a contribuição para o esvaziamento das funções do Estado, enquanto promotoras e executoras de políticas públicas (STEIL; CARVALHO, 2007). Nesse sentido, Gohn (2010) atesta que tal esvaziamento reforça os princípios neoliberais de Estado mínimo, além de relegar a um segundo plano a capacidade das ONGs

[...] de contribuir para uma nova cultura política via intervenções no debate político, na opinião pública, atuando no plano cultural e simbólico como representantes de sujeitos políticos determinados (as mulheres, por exemplo) 
e como interlocutoras e defensoras de propostas inovadoras e, muitas vezes, altamente polêmicas. (p. 15).

Dessa forma, para a realização das ações propostas “[...] não são mais necessários militantes com consciência de classe e imbuídos de racionalidade política estratégica, mas de voluntários que se engajem em ações locais concretas de intervenção social [...]” (STEIL; CARVALHO, 2007, p. 187). Portanto, parece haver uma mudança no caráter das ações desenvolvidas, as quais passam a ser realizadas de forma difusa e não mais ligadas diretamente com as demandas vindas das bases populares, como se caracterizava anteriormente com os movimentos sociais (STEIL; CARVALHO, 2007).

A partir disso, as ONGs começam a se especializar para buscar recursos financeiros em órgãos governamentais nacionais e organismos financeiros internacionais, haja vista o período de dificuldades de arrecadação de recursos vivido nessa época. Tal processo demandou maior profissionalização de seus membros, o que acarretou em um maior nível de exigência quanto à competência técnica dos mesmos e uma descaracterização do caráter militante do início das organizações (STEIL; CARVALHO, 2007).

Nesse contexto Gohn $(2010 ; 2013)$ enuncia a constituição de dois tipos de ONGs, as cidadãs e as do terceiro setor.

As primeiras [cidadãs] se fundam numa cultura política que priorizam, nos processos de mudanças e transformações sociais, a conquista, defesa ou ampliação de diferentes tipos de direitos da população como um todo e a emancipação sociopolítica e econômica de amplas camadas da população que se encontram totalmente excluídas do acesso ao mercado de trabalho, dos benefícios da civilização moderna para uma vida digna e com justiça social. As entidades do Terceiro Setor atuam de acordo com critérios vagos de um humanismo liberal, que visa ajudar o próximo, de preferência via trabalho voluntário, criando instituições bastante atreladas às políticas públicas, segundo os critérios preconizados por essas políticas, os quais falam em nome do social e da coisa pública, mas priorizam, na ação concreta, o atendimento emergencial, sem atuar nas causas dos problemas sociais. (GOHN, 2010, p. 14).

Assim, as ONGs cidadãs trabalham por meio dos princípios da educação popular, estando ligadas aos preceitos das primeiras ONGs. Já as ONGs terceiro-setoristas trazem uma perspectiva de trabalho ligado aos princípios neoliberais, contribuindo para a manutenção do status quo. Por outro lado, Machado (2012) alerta para o perigo de tal dualidade, uma vez que desconsidera a heterogeneidade das ONGs e a contradição presente nas mesmas em que apesar de apresentarem uma funcionalidade para o capitalismo, promovem ações críticas ao modelo neoliberal. 
Não se pode homogenizar as ações de tais organizações, como se não existisse nenhuma que realizasse práticas compatíveis com um perfil progressista, a exemplo de determinadas ONGs que desde a sua origem seguem prestando assessoria aos movimentos sociais por meio da educação popular, pois essas, em especial, ainda que apresentem uma certa funcionalidade ao sistema capitalista (já que, como todas as organizações não-governamentais, assumem determinadas responsabilidades sociais do Estado), também promovem ações críticas e até mesmo opostas ao neoliberalismo. Daí o caráter contraditório. Elas não são simplesmente isso ou aquilo, isto é, não são "motores de transformação" ou a "face do neoliberalismo": são a unidade dos opostos (MACHADO, 2012, p. 3496).

Além disso, Steil e Carvalho (2007) sugerem que apesar do contexto neoliberal, é possível entender o trabalho das ONGs enquanto respostas da sociedade civil aos problemas da realidade, o que por um lado demonstra uma "sociedade mais fortalecida em sua capacidade de ação e organização [...] [e de outro] mais fragilizada pelos processos de globalização neoliberais [...]" (p. 192), alertando também para o fato de que as ações propostas pelos projetos de ONGs são "[...] limitadas no tempo, de caráter complementar e não substitutivos das políticas públicas.” (p. 192).

\subsection{ONGs ambientalistas e a Educação Ambiental}

No contexto de surgimento das ONGs, apresentado no subitem anterior, há um tipo que atua diretamente com as questões ambientais. Essas organizações possuem estreita relação com o movimento ambientalista, sendo necessário, portanto, entender as características de tal movimento para se compreender a constituição daquelas. Além disso, permitirá entender as diferentes concepções sobre meio ambiente e Educação Ambiental presentes e desenvolvidas por muitas dessas ONGs, assim como identificar a existência de posturas dialógicas e antidialógicas.

O movimento ambientalista surge de forma descentralizada, em vários pontos do mundo, marcado por reivindicações de pequenos grupos em relação a problemas ambientais locais. Nesse contexto, destaca-se o surgimento, na segunda metade do século XIX, dos primeiros grupos protecionistas na Grã-Bretanha e nos Estados Unidos (MCCORMICK, 1992).

Na Grã-Bretanha o movimento surge a partir da preocupação com a proteção da vida silvestre, expandindo-se mais tarde para a questão do refúgio da vida agitada dos centros industriais. Nos Estados Unidos o movimento se dividiu em duas frentes: a preservacionista, ligada à defesa de áreas naturais intocadas pelo ser humano, defendendo apenas dois tipos de 
uso para essas áreas: recreação ou educação; e a conservacionista, a qual enxergava a natureza enquanto fonte de recursos a serem utilizados de forma racional (MCCORMICK, 1992).

Dessa forma, a adesão por parte do público era muito pequena nesse início, ganhando notoriedade à medida que a ciência aprofundava o conhecimento sobre a natureza e as pessoas tomavam contato com outras realidades, que não àquelas que estavam circunscritas. Portanto, o processo de maturação em torno do novo paradigma ambiental foi lento, caracterizado pela formação de grupos de indivíduos preocupados com a questão ambiental, os quais se uniram para formar coalizões, que, por sua vez, constituíram-se enquanto movimentos nacionais, alcançando, por fim, o estágio de um movimento multinacional. Porém, essa "[...] evolução foi episódica, com períodos de expansão dinâmica intercalados por tempos de sonolência." (MCCORMICK, 1992, p. 22).

É no período pós Segunda Guerra Mundial, mais precisamente na década de 1960, que o movimento ambientalista vive uma revolução, na qual há um aprofundamento da questão ambiental, em que se busca ir além da proteção da vida selvagem ou do uso racional de recursos, incorporando diversas pautas como o pacifismo, o feminismo, o direito dos consumidores etc., passando-se a focar na sobrevivência dos seres humanos e na crise gerada pelas relações degradadoras que estes estabeleceram entre si e com o ambiente (CASTELLS, 1999; MCCORMICK, 1992).

Essa nova postura, a qual fez McCormick (1992) diferenciar tal momento do movimento, chamando-o de Novo Ambientalismo, emergiu a partir de alguns fatores importantes, como “[...] os efeitos da afluência, a era dos testes atômicos, o livro Silent Spring [de Rachel Carson], uma série de desastres ambientais bastante divulgados, avanços nos conhecimentos científicos e a influência de outros movimentos sociais.” (p. 66).

Na segunda metade da década de 70 vários grupos ambientalistas se estruturaram a partir da liberalização política para a questão ambiental promovida pela Conferência de Estocolmo, em 1972 (JACOBI, 2000), trazendo

a militância para o campo das lutas sociais e por melhorias na qualidade de vida, delineando os elementos do que viria a caracterizar o ideário ambientalista. Ideário este que, no Brasil e em outros países da América Latina, acabou conectando-se às lutas por liberdades democráticas e por direitos humanos (SORRENTINO, 2005, p. 1).

No entanto, nessa época o governo brasileiro defendia a entrada de indústrias poluidoras no país, sob o pretexto do crescimento econômico, o que gerou um cenário de pressão internacional, resultando na criação da Secretaria Especial do Meio Ambiente 
(SEMA) no nosso país, responsável por elaborar estratégias para conservação do ambiente brasileiro (JACOBI, 2000; DIAS, 2004).

Nesse contexto, Jacobi (2000) afirma que o ambientalismo brasileiro era um movimento ainda bastante restrito, caracterizado por um confinamento organizacional em que havia apenas alguns grupos da sociedade civil e de pessoas preocupados com a questão ambiental. Complementa dizendo que

Os grupos se concentram, na sua maioria, na região Sul-Sudeste e são compostos por ativistas que desenvolvem atividades em comunidades alternativas rurais, iniciam ações de educação ambiental, trabalhos de proteção e recuperação de ambientes degradados, bem como de proteção a ambientes ameaçados, e denunciam os problemas de degradação do meio ambiente, apoiados financeiramente por um grupo restrito de simpatizantes. Sua atuação está centrada, nesse período de implantação e consolidação, na denúncia e na conscientização pública sobre a degradação ambiental, principalmente com enfoque local." (p. 137).

Parte desses grupos se constituiu organizacionalmente enquanto associações ambientalistas, mais conhecidas como ONGs ambientalistas a partir do final da década de 80, as quais são definidas no artigo $1^{\circ}$ da Resolução CONAMA 292 como as entidades que possuem "[...] como objetivo principal, no seu estatuto e por intermédio de suas atividades, a defesa e proteção do meio ambiente." (CONAMA, 2002, p. 788).

É ainda nesse período que se percebe os limites da concepção desenvolvimentista, em que os problemas sociais não apresentam melhoras e a extensão dos problemas ambientais se agrava. As queimadas na Amazônia e o desmatamento da Mata Atlântica, por exemplo, proporcionaram a articulação entre associações ambientalistas nacionais e internacionais, europeias e norte-americanas, para lutar contra as ações degradadoras do ambiente brasileiro (JACOBI, 2000).

Na década de 1980 três aspectos marcam o horizonte do movimento ambientalista brasileiro: o aprimoramento dos instrumentos legais de gestão ambiental, haja vista que o aparato jurídico-institucional brasileiro existente não permitia a superação dos problemas ambientais; a entrada de ambientalistas no campo político institucional; e pela profissionalização de ONGs ambientalistas e sua aproximação com as ONGs sociais (JACOBI, 2000).

A partir disso, as ONGs começaram a se reestruturar internamente, buscando a profissionalização do trabalho desenvolvido. Além disso, há uma mudança de postura, migrando de um caráter reativo para um proativo, de forma que passam a agregar às ações de 
denuncia a formulação de alternativas de conservação dos ecossistemas, o melhoramento da qualidade da água, do solo e do ar, a realização de processos de educação ambiental, a disponibilização de informações, ampliando seu acesso à sociedade e estimulando a agricultura sustentável, recebendo para isso recursos de instituições de cooperação internacional e de organizações multilaterais (JACOBI, 2000).

Entrando na década de 1990, a Conferência das Nações Unidas sobre o Meio Ambiente e Desenvolvimento (Eco-92) estimulou em sua etapa preparatória a articulação entre ONGs e movimentos sociais por meio da criação do Fórum Brasileiro de ONGs e Movimentos Sociais para o Meio Ambiente e Desenvolvimento (FBOMS), o qual objetivou fomentar a transversalidade, o controle social, a democracia e a participação da sociedade brasileira na Conferência, discutindo os desafios para a sustentabilidade (JACOBI, 2000; SORRENTINO, 2005).

Além disso, um grupo de trabalho das ONGs de diversos países, tanto do Norte quanto do Sul, liderados por organizações não governamentais do Brasil, durante a Conferência da Sociedade Civil sobre o Meio Ambiente e Desenvolvimento, elaborou o Tratado de Educação Ambiental para Sociedades Sustentáveis e Responsabilidade Global (TEASS), documento referência para a EA, o qual apresenta diversos princípios da área, destacando-se aqui a perspectiva dialógica, crítica, política, holística, democrática e de valorização das diferenças (DIAS, 2004; FÓRUM GLOBAL DAS ONGs, 1992), o que demonstra o engajamento e a importante contribuição dada pelas ONGs à educação ambiental.

Nesse sentido, Ferreira (1999) afirma que as ONGs ambientalistas tiveram um papel importante na constituição do campo político ambiental, pressionando o poder público e exigindo transparência no processo de tomada de decisão, desenvolvendo pesquisas, realizando projetos e estabelecendo parcerias nacionais e internacionais. "Seu papel principal na atualidade talvez possa ser resumido em apontar evidências de que há inúmeras possibilidades de superar a crise global atual” (p. 45).

Além disso, ressalta a importante possibilidade gerada pelos trabalhos das ONGs na construção de pontes de diálogo entre pessoas com diferentes experiências de vida. De um lado estão os sujeitos da classe média intelectualizada, membros das ONGs, e de outro o público-alvo, geralmente grupos sociais marginalizados, como as comunidades tradicionais (FERREIRA, 1999). 
No entanto, no final da década de 1990, apesar da grande preocupação com a questão ambiental e o desejo de um novo projeto de sociedade, o movimento ambientalista brasileiro não chegou a um consenso sobre os caminhos para alcançá-la, o que denota de um lado sua grande diversidade de concepções teóricas e metodológicas e de outro o grande desafio de se trabalhar com ela (FERREIRA, 1999).

Nesse sentido, Sorrentino (1995) destaca a existência de duas correntes de pensamento presentes no movimento ambientalista a partir desse momento histórico: a do Desenvolvimento Sustentável que agrega “[...] empresários, governantes e uma parcela das organizações não governamentais [...]” (p. 16) e a das Sociedades Sustentáveis “[...] aglutinando aqueles que sempre estiveram na oposição ao atual modelo de desenvolvimento e que acreditam que a primeira corrente é só uma nova roupagem para a manutenção do 'status quo'.” (p. 16), estando alinhadas a essa segunda corrente as ONGs integrantes do FBOMS.

Na mesma linha de pensamento, Diegues (1992) contesta a lógica de desenvolvimento sustentável, o qual se constitui enquanto um paradigma ocidental que desconsidera a diversidade e, portanto, não acolhe as diferenças.

não existe um único paradigma de sociedade do bem-estar (a ocidental) a ser atingido por vias do "desenvolvimento" e do progresso linear. Há necessidade de se pensar em vários tipos de sociedades sustentáveis, ancoradas em modos particulares, históricos e culturais de relações com os vários ecossistemas existentes na biosfera e dos seres humanos entre si. Esse novo paradigma a ser desenvolvido se baseia, antes de tudo, no reconhecimento da existência de uma grande diversidade ecológica, biológica e cultural entre os povos que nem a homogeneização sociocultural imposta pelo mercado capitalista mundial, nem os processos de implantação do "socialismo real" conseguiram destruir. (p. 23).

Nesse sentido, Diegues (2008) tece importantes críticas sobre as perspectivas antagônicas adotadas pelas ONGs ambientalistas brasileiras, ressaltando que muitas delas foram, e ainda são influenciadas pelas filosofias das grandes ONGs ambientalistas do Norte World Wildlife Fund (WWF), Conservation International (CI), Nature Conservancy (TNC) e outras, as quais trabalham pelo viés preservacionista, buscando a proteção do ambiente natural, entendido como fauna, flora e fatores abióticos (ar, água, solo), desacompanhada de uma perspectiva crítica sobre o sistema de produção e consumo urbano-industrial e desconsiderando as questões sociais e culturais como parte dos problemas ambientais.

Além disso, ressalta que o poder dessas grandes ONGs se expande nos anos 1980 no contexto internacional com a consolidação do modelo neoliberal de Estado mínimo e pela influência junto às organizações financeiras mundiais, como o Banco Mundial, obtendo 
fundos para financiar diversos projetos. Dessa forma, realizam repasses financeiros às ONGs do Sul impondo como condição a adoção da perspectiva preservacionista e suas estratégias metodológicas, trazendo sérias consequências socioculturais, principalmente para as populações tradicionais que a gerações vivem em áreas relevantes para a preservação, gerando conflitos e desorganização de seus modos de vida (DIEGUES, 2008), haja vista o caráter impositivo e autoritário, antidialógico, de tais estratégias.

Em contraposição a tudo isso, Diegues (2008) afirma a importância de se desenvolver pesquisas sobre a conservação ambiental, a partir da perspectiva da ecologia social, considerando as especificidades dos países do Sul e não importando uma ciência do Norte indiscriminadamente como se fosse a solução para os problemas ambientais. Além disso, fala da necessidade de se trabalhar em conjunto com as comunidades de forma democrática e participativa, valorizando o conhecimento tradicional, para que os interesses de todos sejam considerados na conservação do ambiente, abrindo a possibilidade para a emergência do diálogo.

Tal diversidade de concepções do movimento ambientalista impacta diretamente os processos de educação ambiental desenvolvidos pelas ONGs, caracterizados por um leque de ideologias, variando desde concepções ligadas apenas a aspectos do ambiente natural, como flora e fauna, atuando por meio da transmissão de informações e de comportamentos ambientalmente "adequados", numa perspectiva "bancária" da educação e, assim, antidialógica (CARVALHO, 2001; SAUVÉ, 2005; FREIRE, 1981) até concepções mais complexas por considerar aspectos sociais, culturais, econômicos, políticos, éticos, além dos ambientais, de maneira interdisciplinar e transdisciplinar em diferentes escalas espaciais, tanto local quanto global, considerando os participantes do processo educador ambientalista enquanto sujeitos promotores de transformações (ANDRADE, 2013; DIEGUES, 2008; FIGUEIREDO, 2003; 2006; FREIRE, 1983; LOGAREZZI, 2010; NICOLESCU, 1999; SORRENTINO et. al., 2013) e, portanto, assumindo os princípios dialógicos.

Não há, portanto, uma definição única sobre ONGs ambientalistas que desenvolvem processos de educação ambiental. É importante que as ONGs tenham clareza sobre seus princípios teóricos e metodológicos e avaliem permanente e continuadamente se estes estão presentes na prática cotidiana. Além disso, pesquisas que realizem essas análises são relevantes por fornecer mais subsídios a tal processo.

Nesse sentido, destaca-se a pesquisa desenvolvida por Tristão (2011) a qual analisou cinco ONGs ambientalistas (Instituto 5 Elementos; IPESA; SEAE; Instituto Refloresta; SOS 
Mata Atlântica; e Instituto Supereco). A partir das análises a autora constatou que existe nas ONGs uma tendência maior em trabalhar com metodologias que permitam maior interação entre os sujeitos do processo educador em detrimento das tradicionais, com caráter de transmissão de informações, o que demonstra a grande oportunidade gerada pelas ONGs, mais desprendidas das amarras da estrutura tradicional da educação, para buscar implementar processos educadores alinhados à uma EA para Sociedades Sustentáveis.

Fossaluza (2015), por sua vez, investigou por meio de pesquisa quanti-qualitativa as ONGs ambientalistas do Estado de São Paulo, buscando realizar o mapeamento das mesmas e analisar o caráter das ações de EA desenvolvidas por elas, a partir da concepção de EA crítica. Analisou 276 organizações do Estado a partir das três macrotendências da EA sugerida por Layrargues e Lima (2014) (conservacionista, pragmática e crítica). A partir disso, constatou que há uma predominância do caráter conservador nas ações de EA desenvolvidas pelas ONGs ambientalistas, com o predomínio numérico de ações pontuais em detrimento de ações contínuas e sofrendo a influência dos financiadores nas concepções e atividades de educação ambiental (FOSSALUZA, 2015).

Além disso, notou que no discurso as ONGs ambientalistas adotam as ideias de uma EA crítica, mas não a praticam em suas ações, o que denota uma contradição entre o entendimento das concepções em torno da EA e sua implementação na prática. Afirma, por fim, que o alcance das ações de EA realizadas pelas ONGs ambientalistas paulista é grande, quantitativamente falando. No entanto, a qualidade dessas ações é limitada, não contribuindo para a transformação da sociedade que enunciam em seus objetivos (FOSSALUZA, 2015).

Araujo (2006) ao investigar ONGs ambientalistas do Litoral Norte do Estado de São Paulo também verificou a falta de coerência entre discurso e prática sobre a EA, afirmando que apesar de enunciarem os princípios da criticidade e da emancipação, adotam práticas conservadoras, o que se constitui enquanto um importante desafio a ser superado.

Outra pesquisa muito pertinente para o tema desta dissertação por tratar da relação entre ONG ambientalista e pescadores artesanais, por meio da educação ambiental, foi desenvolvida por Suassuna (2004). A autora analisou as intervenções de EA realizadas pelo Projeto Tamar junto às comunidades pesqueiras do litoral brasileiro, verificando a presença da perspectiva preservacionista, criticada por Diegues (2008), como orientadora do processo, focando na proteção das espécies de tartarugas marinhas e relegando ao segundo plano as demandas socioculturais dos pescadores, inclusive causando rupturas em seus modos de vida. Portanto, se de um lado existe um grande potencial dialógico na relação entre membros de 
ONGs e público-alvo, como sugere Ferreira (1999), de outro há ainda uma série de desafios a serem vencidos para se superar a antidialogicidade.

Dessa forma, é possível perceber a partir do histórico de surgimento das ONGs, do movimento ambientalista e das ONGs ambientalistas alguns pontos importantes sobre o diálogo e sua presença nessas organizações. As primeiras ONGs, os centros de educação popular, nascem a partir dos princípios dialógicos enunciados por Paulo Freire, se constituindo enquanto uma importante herança para as ONGs atuais, sejam elas ambientalistas ou não.

O ambientalismo, por sua vez, surge com uma forte presença da perspectiva preservacionista, preocupada com a proteção da flora, da fauna e dos elementos abióticos, emergindo posteriormente a perspectiva socioambientalista, a qual agrega à anterior a dimensão social (JACOBI, 2000). No entanto, tal perspectiva fica mais presente no discurso do que na prática com o fortalecimento das grandes ONGs internacionais, as quais assumem e propagam uma visão da questão ambiental desvinculada do social (DIEGUES, 2008). A disseminação desses princípios reforça a utilização de estratégias impositivas, portanto, antidialógicas, uma vez que busca a proteção ambiental a despeito dos problemas sociais e culturais que se possa causar, preterindo a abertura ao Outro e se fechando em pressupostos pré-estabelecidos.

Em decorrência da grande influência das ONGs internacionais se verifica um efeito direto nas práticas de educação ambiental desenvolvidas pelas diversas ONGs nacionais, ainda que em diferentes medidas, de forma que muitas adotaram, e ainda adotam uma concepção conservadora de educação (SUASSUNA, 2004; ARAUJO, 2006; FOSSALUZA, 2015), na qual se busca prescrever regras de comportamentos ambientalmente "corretos" (CARVALHO, 2001), a partir da transmissão de informações (SAUVÉ, 2005), não reconhecendo os saberes populares (DIEGUES, 2008) e, portanto, caracterizando-se por uma postura antidialógica, na qual se presume que os ambientalistas são os donos do saber e possuem a missão de estendê-lo, como critica Freire (1983), às pessoas.

Dessa forma, é de vital importância a constante avaliação, interna e externa, dos princípios teóricos e metodológicos que guiam as ONGs, analisando se eles se aproximam ou se distanciam da herança dialógica deixada pelos centros de educação popular e se buscam ir além da proteção da vida selvagem ou do uso racional de recursos, considerando e incorporando as lutas sociais. E se em consequência deles desenvolvem processos de educação ambiental marcados pela predominância da antidialogicidade ou da dialogicidade. 
Essas análises avaliativas são importantes para a identificação dos pressupostos, o que possibilita a superação da antidialogicidade, tão presente e muito pouco reconhecida por nós, para alcançar a tão sonhada transição para sociedades sustentáveis. Alguns questionamentos podem auxiliar essa avaliação: em que direção a ONG parece estar caminhando, a uma que não agrega a dimensão social à ambiental, que não questiona o paradigma vigente e adota princípios de uma educação ambiental impositiva, prescritiva e, portanto, antidialógica ou a uma que busca considerar a complexidade da questão ambiental vinculada às diferentes dimensões da realidade - social, cultural, econômica, filosófica, religiosa etc., questionando o paradigma atual e adotando uma educação ambiental baseada nos princípios dialógicos? A quem e a que valores a ONG está servindo? O trabalho desenvolvido almeja a transformação da realidade? Se sim, as ações planejadas e executadas contribuem para essa transformação ou apenas estão mantendo o status quo e, portanto, se está iludindo e garantindo um futuro de frustração?

Tendo em vista tal dualidade, enunciada pelos autores supracitados (DIEGUES, 1992; 2008; GOHN, 2010; MACHADO, 2012; SORRENTINO, 1995), entre ONGs ligadas aos princípios neoliberais e à concepção de desenvolvimento sustentável e ONGs ligadas aos princípios de transformação socioambiental e à concepção de sociedades sustentáveis, reconhece-se aqui os limites de transformar tal dualidade em categorias fixas as quais as ONGs podem ser enquadradas. Portanto, para análise do caso aqui estudado se utilizará esses dois polos para averiguar em que direção há uma maior aproximação, sem pretender taxá-lo em uma ou outra categoria. 


\section{PESCADORES ARTESANAIS}

Neste capítulo serão apresentados os aspectos históricos, internacionais e nacionais, ligados aos pescadores artesanais, o Código de Conduta para a Pesca Responsável e algumas pesquisas de educação ambiental desenvolvidas junto a esse público, com o intuito de compreender como o diálogo se fez/faz, ou não, presente na constituição histórica da identidade desse ator social.

\subsection{Aspectos históricos e contradições}

\subsubsection{Contexto histórico internacional}

A pesca é uma atividade muito antiga desenvolvida pela humanidade para obtenção de proteína. No período anterior ao Neolítico as sociedades primitivas já coletavam moluscos, ostras e mexilhões, para sua alimentação. As civilizações antigas, como a egípcia, grega e romana, apresentavam um considerável consumo de peixe em suas dietas, principalmente com a aparição do cristianismo, sendo a pesca uma atividade exercida por escravos e o comércio do pescado por comerciantes especializados (DIEGUES, 1983).

Na Idade Média o exercício da atividade pesqueira avançou, caracterizando-se por dois momentos. O primeiro em que a pesca era realizada no interior dos feudos, sendo exercida em lagunas e zonas costeiras e o segundo em que a pesca era realizada pelas cidades medievais, sendo praticada na Escandinávia, Mediterrâneo, Bretanha, Normandia, Cantábrico e Inglaterra (DIEGUES, 1983).

Com o advento da expansão da pesca de longa distância com os barcos a vela, nos séculos XVII e XVIII, surge um novo modo de produção pesqueira, baseado "[...] nas premissas do capitalismo comercial e não mais na unidade familiar.” (DIEGUES, 1983, p. 20), uma vez que os comerciantes europeus eram os donos das embarcações, dividindo com os mestres e pescadores os lucros obtidos durante a temporada de pesca (DIEGUES, 1983).

O constante crescimento da pesca, acompanhado pela perspectiva mercantilista, contribuiu para a crescente desvalorização da pesca de pequena escala e, portanto, do pequeno pescador. Tal fato se intensificou com a invenção do barco a vapor, o qual substituiu o barco a vela, possibilitando enorme capacidade de captura de peixes, atingindo centenas de toneladas (DIEGUES, 1983). Muitos pescadores de barcos a vela se revoltaram com a invenção, haja vista que os 
[...] barcos a vapor, com 14 tripulantes, pescavam o equivalente a 80 veleiros tripulados por 600 pescadores. [Além disso] $\mathrm{O}$ desembarque dessa enorme captura causava a baixa dos preços do pescado e punha em perigo a sobrevivência dos pescadores embarcados em barcos a vela (DIEGUES, 1983, p. 21).

Além das dificuldades impostas aos pequenos pescadores citadas acima, há também o desaparecimento de suas vilas, as quais deram lugar a grandes portos para acolher as grandes embarcações motorizadas. Nesse contexto, os pequenos pescadores se viram obrigados a buscar trabalho nos grandes barcos a vapor, financiados por empresas ou armadores capitalistas que não estavam diretamente envolvidos com as atividades de captura, tendo um impacto significativo em seus modos de vida (DIEGUES, 1983).

Portanto, é possível notar que com o advento da sociedade urbano-industrial e sua visão mecanicista e utilitarista da natureza nasce um conflito que perdura até a atualidade: "progresso" urbano-industrial versus estilo de vida pré-capitalista de populações tradicionais, representadas aqui pelos pescadores artesanais, os quais realizam a pesca de pequena escala, capturando uma quantidade de pescado para consumo de suas famílias e um pequeno excedente comercializável, sendo a mão-de-obra empregada constituída pelo próprio núcleo familiar podendo receber ajuda de conhecidos. Ademais, são dotados de um saber tradicional, transmitido de geração a geração, formando um conjunto rico de saberes referentes ao mundo natural e sobrenatural (DIEGUES, 2000; 2001).

Esse conflito é marcado pela imposição dos valores capitalistas a essas populações, o que contribui sobremaneira para a marginalização e descaracterização de suas culturas (DIEGUES, 2001). Nesse sentido, Diegues (1995) apresenta as onze falácias sobre a pesca e o pescador artesanal que reforçam a desvalorização cultural dessas comunidades tradicionais:

1. "Os pescadores artesanais são indolentes e não trabalham com regularidade" (p. 92, negrito nosso);

2. "Os pescadores artesanais são mendigos de praia e constituem um problema social a ser tratado por programas assistenciais" (p. 93, negrito nosso);

3. "A pesca artesanal é um setor de transição entre a pesca de auto-subsistência e a pesca empresarial-capitalista e, portanto, tende a desaparecer" (p. 94, negrito nosso);

4. "A pesca artesanal é ineficiente" (p. 95, negrito nosso);

5. "A pesca artesanal produz somente pescado de baixa qualidade" (p. 96, negrito nosso);

6. "O pescador artesanal é ignorante, e resiste às mudanças tecnológicas" (p. 97, negrito nosso);

7. “O pescador artesanal é passivo e não sabe defender os seus direitos" (p. 98, negrito nosso);

8. “Os pescadores artesanais são isolados" (p. 98, negrito nosso); 
9. “Os pescadores artesanais são individualistas e não se organizam” (p. 99, negrito nosso);

10. “Os pescadores artesanais são predadores” (p. 99, negrito nosso);

11. "O pescador artesanal é um profissional de tempo integral." (p. 100).

Esse discurso ideológico de que os pescadores artesanais são mendigos, indolentes, ignorantes, passivos, isolados, individualistas, predadores, desorganizados enquanto classe e que desenvolvem uma pesca ineficiente, de baixa qualidade e que tende a desaparecer evidencia o forte caráter antidialógico vivido por essas populações, de forma que "sua experiência existencial se constitui dentro das fronteiras do antidiálogo." (FREIRE, 1983, p. 31) e, portanto, relegar a responsabilidade apenas aos pescadores pelos desafios que enfrentam é uma grande injustiça. No contexto histórico brasileiro essa situação se repete como se pode verificar a seguir.

\subsubsection{Contexto histórico da pesca no Brasil}

A pesca no Brasil até os anos de 1960 era predominantemente realizada por pescadores artesanais e armadores, proprietários das embarcações e petrechos de pesca, e caracterizada por um cenário de baixa produção (DIEGUES, 1983). Esse cenário era formado por três fatores: primeiro, o alto preço alcançado pelos pescadores artesanais com a venda do pescado; segundo, as condições dos mares brasileiros, caracterizados por grande diversidade de espécies, mas baixa abundância de indivíduos (DIEGUES, 1983); e terceiro, a falta de gestão dos recursos pesqueiros pelo Estado até a década de 1960, de maneira que as taxas de captura não excediam os limites dos estoques pesqueiros (MARRUL-FILHO, 2001).

Foi então, para tentar acabar com esse cenário de baixa produtividade e altos preços para consumo, que o governo brasileiro criou em 1962 a Superintendência do Desenvolvimento da Pesca (SUDEPE), responsável por toda a gestão da atividade pesqueira e do uso da biodiversidade aquática (NETO, 2010) e passou a implementar, em 1967, um programa de incentivos fiscais, por meio do Decreto-Lei $\mathrm{n}^{\circ} 221 / 67$, com o propósito de desenvolver a pesca nacional (DIEGUES, 1983; MARRUL-FILHO, 2001).

A SUDEPE incentivou fortemente a modernização e a industrialização do setor pesqueiro, desconsiderando, no entanto, o pescador de pequena escala, já que os incentivos foram para empreendedores de outros setores econômicos (DIEGUES, 1983; NETO, 2010). Com esse novo cenário, várias empresas recém-criadas começaram a investir nos materiais necessários para desenvolver suas atividades de pesca. Porém, a mentalidade imediatista visando o rápido retorno dos investimentos fez com que a captura do pescado fosse realizada 
de maneira desordenada e sem planejamento, ignorando as condições ambientais, fato que levou à situação de sobrepesca diversos recursos pesqueiros, como o camarão (DIEGUES, 1983).

Além disso, o esgotamento desses primeiros estoques alvo da pesca industrial fez com que as empresas passassem a comprar a produção do pescador artesanal na tentativa de manter seus níveis de produção, aumentando assim a exploração indiscriminada e colaborando com a degradação e esgotamento dos ecossistemas responsáveis por fornecer os meios de subsistência para os pescadores de pequena escala (DIEGUES, 1983).

Em meio a esse contexto competitivo e injusto para o pequeno pescador, muitos se viram obrigados a ceder sua força de trabalho para as empresas do setor, sendo este um dos objetivos do Decreto-Lei n 221/67. Porém, como era de se esperar, as medidas de incentivos do governo não tiveram o resultado almejado, já que muitas das novas empresas desse setor faliram, cerca de 40\% (DIEGUES, 1983).

De acordo com Neto (2010), o fracasso do modelo adotado pela SUDEPE se deve a vários fatores, como o uso inadequado de incentivos fiscais, a fraca atenção dada à pesca artesanal e a maneira predatória e desordenada na utilização dos recursos pesqueiros promovendo um cenário de sobrepesca, ou mesmo o colapso de certos recursos como a sardinha verdadeira.

Ademais, Diegues (1983) afirma que o descaso com a forma de manejo dos recursos pesqueiros realizada pelos pescadores artesanais e toda a dinâmica do setor no período anterior à década de 1960 foi o grande erro. Aponta que a pesca deveria ter sido desenvolvida no Brasil mediante a lógica de produção dos pescadores artesanais, visto as condições do mar brasileiro já citadas anteriormente.

Após esse momento, o Instituto Brasileiro do Meio Ambiente e dos Recursos Naturais Renováveis (IBAMA) assumiu a gestão dos recursos pesqueiros, de 1989 a 1998, e adotou medidas diferentes visando à recuperação dos estoques pesqueiros em situação de sobrepesca. Essas medidas contribuíram efetivamente para a recuperação dos estoques, inclusive atingindo um novo cenário positivo de produção após alguns anos de gestão. Porém, em 1998 se apresenta um novo momento marcado pelo Decreto $n^{\circ} 2.840$ de novembro de 1998, o qual trouxe uma mudança importante e polêmica em se tratando das competências na gestão dos recursos pesqueiros (NETO, 2010). 
Essa mudança se constituiu na separação das responsabilidades quanto à gestão entre Ministério do Meio Ambiente (MMA) e Ministério da Agricultura, Pecuária e Abastecimento (MAPA). Essa divisão estava atrelada a situação dos estoques pesqueiros, de forma que se o estoque estivesse em situação de sobrepesca ou em vias de atingir tal estado a gestão seria responsabilidade do MMA, enquanto os estoques passíveis de exploração seriam responsabilidade do MAPA (NETO, 2010).

Essa divisão foi justificada a partir da ideia de que os estoques ameaçados deveriam ser geridos por um órgão ambiental competente e os estoques passíveis de exploração por um órgão preocupado com o desenvolvimento econômico do setor pesqueiro. É possível notar a separação perigosa realizada pelo poder público, em que se dividiu aquilo que não pode ser dividido (NETO, 2010).

Com a criação do Ministério da Pesca e Aquicultura (MPA), pela Lei $\mathrm{n}^{\circ} 11.958$ de 2009, esse modelo fragmentado de gestão é substituído por um unificado. No entanto, essa união foi marcada pela sobreposição de poderes, já que o MPA se tornou o responsável pela coordenação e gestão dos recursos, tendo assim, mais influência e poder do que o MMA (NETO, 2010).

Avançando no tempo, foi extinto pelo governo brasileiro, em 2016, o MPA por meio da Lei $n^{\circ} 13.266$ (BRASIL, 2016) e, em 2017, a Secretaria de Aquicultura e Pesca do Ministério da Agricultura, Pecuária e Abastecimento (MAPA) foi transferida para o Ministério da Indústria, Comércio Exterior e Serviços (MDIC) por meio do Decreto ${ }^{\circ} 9.004$ que institui como competência do MDIC a política nacional pesqueira e aquícola, o fomento à produção, a normatização das atividades, a fiscalização, a concessão de licenças, entre outros. Além disso, incumbe ao MDIC e ao MMA, sob a coordenação do primeiro, tratar de aspectos relacionados ao uso sustentável dos recursos pesqueiros (BRASIL, 2017). Tal cenário é preocupante, haja vista que a questão ambiental pesqueira passa a ser responsabilidade de um Ministério que possui como objetivo estimular a competitividade das empresas brasileiras (MINISTÉRIO DA INDÚSTRIA, COMÉRCIO EXTERIOR E SERVIÇOS, 2017), o que pode reforçar a contradição aqui exposta entre modos de vida tradicionais e progresso industrial.

Dessa forma, ficam claros os impactos causados pela imposição dos valores capitalistas às comunidades de pescadores artesanais, os quais têm sua cultura desvalorizada a partir de tal imposição, assim como os impactos ambientais advindos de tal relação, uma vez 
que a exploração desordenada levou, e infelizmente ainda vem levando, inúmeros estoques pesqueiros à sobreexplotação. Por isso, é possível verificar que a situação da pesca no Brasil ainda está muito distante de ser realizada de forma dialógica, valorizando e respeitando os diferentes atores sociais dependentes de tal atividade, como os pescadores artesanais, assim como os limites físicos, químicos e biológicos do ambiente.

\subsection{Código de Conduta para a Pesca Responsável}

Neste subitem é apresentado o Código de Conduta para a Pesca Responsável, um documento internacional que propõe uma nova forma de pesca, elaborado pela Organização das Nações Unidas para a Alimentação e a Agricultura $^{33}$ (FAO-ONU). Sua relevância está no fato de a ONG investigada nesta pesquisa ter utilizado esse documento como base para suas ações com os pescadores artesanais, sendo, portanto, de grande importância o entendimento e discussão dos princípios presentes em tal documento.

Tendo em vista o cenário global de sobreexplotação dos estoques pesqueiros, os impactos causados no ambiente marinho e as perdas econômicas a FAO lançou o Código de Conduta para a Pesca Responsável, em 1995, tendo como base uma série de acordos internacionais, como a Lei do Mar de 1982, a Declaração de Cancun de 1992 e a Declaração do Rio sobre Meio Ambiente e Desenvolvimento firmada na Rio-92, assumindo assim a concepção do desenvolvimento sustentável (FOOD AND AGRICULTURE ORGANIZATION OF THE UNITED NATIONS, 1995; 1999).

O Código tem um caráter global e voluntário, destinando-se a todas as pessoas ligadas e/ou preocupadas com o desenvolvimento da pesca e a conservação dos recursos pesqueiros, apresentando para isso "[...] princípios e padrões internacionais de comportamento para práticas responsáveis com o objetivo de assegurar a efetiva conservação, gestão e desenvolvimento dos recursos vivos aquáticos, com o devido respeito ao ecossistema e a biodiversidade." (FOOD AND AGRICULTURE ORGANIZATION OF THE UNITED NATIONS, 1995, p. 1, tradução nossa ${ }^{34}$ ). Importante salientar que o Código não se limita apenas aos aspectos biológicos da pesca, considerando também o social, o tecnológico, o econômico e o comercial (FOOD AND AGRICULTURE ORGANIZATION OF THE UNITED NATIONS, 1995).

\footnotetext{
${ }^{33}$ Tradução de Food and Agriculture Organization of the United Nations.

34 " [.... principles and international standards of behaviour for responsible practices with a view to ensuring the effective conservation, management and development of living aquatic resources, with due respect for the ecosystem and biodiversity." (p. 1)
} 
Foi elaborado e desenvolvido em conjunto com certos atores ligados à pesca, como organizações intergovernamentais, representantes da indústria pesqueira e ONGs, cabendo aos Governos dos diversos países signatários do Código, entre eles o Brasil, implementá-lo em conjunto com as indústrias e comunidades pesqueiras, estimulando-as a desenvolverem códigos de boas práticas de pesca alinhados com os princípios do Código (FOOD AND AGRICULTURE ORGANIZATION OF THE UNITED NATIONS, 2001), o qual está dividido em 12 artigos, dos quais os cinco primeiros são introdutórios - Natureza e escopo do Código; Objetivos do Código; Relação com outros instrumentos internacionais; Implementação, monitoramento e atualização; Requerimentos especiais para países em desenvolvimento. O sexto artigo apresenta os dezenove princípios do Código e os seis artigos subsequentes abordam as práticas responsáveis de acordo com os seguintes temas: Gestão pesqueira; Operações pesqueiras; Desenvolvimento da aquicultura; Integração das pescas no gerenciamento costeiro; Práticas pós-captura e comércio; e Pesquisas relacionadas à pesca (FOOD AND AGRICULTURE ORGANIZATION OF THE UNITED NATIONS, 1995; 1999).

Destacaremos aqui quatro dos dezenove princípios que apresentam aspectos de uma abertura dialógica e se referem aos pescadores artesanais. O princípio 6.4 diz que "decisões de gestão e conservação para a pesca devem ser baseadas nas melhores evidências científicas disponíveis, considerando o conhecimento tradicional [...], assim como fatores ambientais, econômicos e sociais relevantes." (FOOD AND AGRICULTURE ORGANIZATION OF THE UNITED NATIONS, 1995, p. 5, tradução nossa ${ }^{35}$ ) e o princípio 6.13 o reforça à medida que estimula a transparência nos processos de tomada de decisão, a partir da participação de diversas organizações, entre elas as de pescadores (FOOD AND AGRICULTURE ORGANIZATION OF THE UNITED NATIONS, 1995). Tais princípios estimulam uma importante possibilidade para a ocorrência do diálogo, uma vez que alia as evidências científicas com o conhecimento tradicional dos pescadores. Por outro lado, fica a cargo dos governos, empresas pesqueiras, pescadores e demais interessados, compreendendo aqui as ONGs, a definição de como aproveitar tal oportunidade, o que pode incorrer no risco de se constituir enquanto um princípio presente apenas no discurso, caracterizado por uma intenção genuína, mas desprovida de conhecimento para executá-la.

\footnotetext{
35 "Conservation and management decisions for fisheries should be based on the best scientific evidence available, also taking into account traditional knowledge [...], as well as relevant environmental, economic and social factors." (p. 5)
} 
Além disso, tendo em vista a participação dos pescadores na formulação e implementação de políticas ligadas à implementação do Código, o princípio 6.16 afirma a importância dos Estados de “[...] promoverem a consciência da pesca responsável pela educação e treinamento.” (FOOD AND AGRICULTURE ORGANIZATION OF THE UNITED NATIONS, 1995 , p. 7 , tradução nossa ${ }^{36}$ ). No entanto, não está claro aqui se os pressupostos do Código estão abertos para serem dialogados com as diversas comunidades de pescadores dos países signatários. Caso não esteja, assume-se uma postura impositiva dos princípios da pesca responsável criados pela $\mathrm{FAO}$, não tornando o processo de formulação e implementação de políticas ligadas à pesca um processo dialógico, necessário para um caráter genuinamente participativo e transparente, enunciado e estimulado pelo próprio documento.

A presença do diálogo enquanto um princípio do Código se faz importante, inclusive, para a execução do princípio 6.18, o qual afirma que

[...] os Estados devem proteger os direitos dos pescadores, em especial daqueles engajados na subsistência, pequena escala e pesca artesanal, a uma vida segura e justa, assim como a acesso preferencial, quando apropriado, a áreas de pesca tradicional e recursos nas águas sob sua jurisdição. (FOOD AND AGRICULTURE ORGANIZATION OF THE UNITED NATIONS, 1995, p. 7, tradução nossa ${ }^{37}$ ).

Esses direitos devem ser protegidos a partir do entendimento e valorização da cultura dos pescadores artesanais, como sugere Diegues (1983; 2000; 2001), de forma a não incorrer no modus operandi vigente na pesca, caracterizado pela invasão da cultura capitalista às culturas tradicionais. Nesse sentido, a FAO (2015) elaborou um documento com diretrizes para assegurar a sustentabilidade das pescas de pequena escala, o qual aprofundou os primeiros avanços apresentados no Código de Conduta para a Pesca Responsável referentes às comunidades tradicionais de pescadores, contando com a participação de representantes de pescadores artesanais, organizações da sociedade civil, governos e demais interessados.

Esse documento reconhece os diversos problemas enfrentados pelos pescadores artesanais, como os conflitos com a pesca industrial, a exclusão dos processos de tomada de decisão, a desvalorização e a marginalização dessas populações, propondo princípios importantes para reverter tal quadro, como: direitos humanos e dignidade; respeito às culturas; não discriminação; igualdade e equidade de gênero; equidade e igualdade; consulta e

\footnotetext{
36 “[...]promote awareness of responsible fisheries through education and training.” (p. 7)

37 "States should appropriately protect the rights of fishers and fishworkers, particularly those engaged in subsistence, small-scale and artisanal fisheries, to a secure and just livelihood, as well as preferential access, where appropriate, to traditional fishing grounds and resources in the waters under their national jurisdiction." (p. 7)
} 
participação; Estado de Direito; transparência; prestação de contas; sustentabilidade econômica, social e ambiental; abordagens holísticas e integradas; responsabilidade social; viabilidade social e econômica (FOOD AND AGRICULTURE ORGANIZATION OF THE UNITED NATIONS, 2015).

Dessa forma, todos esses princípios são muito importantes para a superação das relações antidialógicas vividas pelas comunidades de pescadores artesanais, uma vez que buscam extinguir as condições de opressão vividas pelas mesmas. Além disso, essa valorização das culturas tradicionais implica no reconhecimento de seus pressupostos, bem como a abertura para questionamento dos pressupostos ligados à ideia de Pesca Responsável sugerida pela FAO.

No entanto, apesar de todo esse potencial dialógico trazido pelo Código e pelas diretrizes sobre a pesca de pequena escala, há uma crítica importante a ser feita quanto à concepção de desenvolvimento sustentável que os dois documentos adotam, a qual não questiona a lógica paradigmática vigente, responsável pelos problemas socioambientais que vivemos hoje, uma vez que visa conciliar o modelo de crescimento capitalista com a capacidade de suporte do planeta e, portanto, contribui para a manutenção e perpetuação das relações antidialógicas, características de tal modelo, com pescadores artesanais (DIEGUES, 1992; SORRENTINO, 1995). Assim, os documentos de grande alcance da FAO estariam promovendo exatamente o oposto do que almejam e, portanto, a abertura dialógica proposta nos princípios supracitados seria apenas uma intenção sem perspectiva de realização, pois tal concepção não traz mudanças paradigmáticas.

\subsection{Educação ambiental e pescadores artesanais}

Por conta do exposto até aqui os pescadores artesanais constituem atualmente um grupo que merece a atenção dos que trabalham com Educação Ambiental. Respondendo a esse grande desafio que se apresenta de manter a diversidade cultural, o número de estudos relacionados às diferentes comunidades tradicionais tem aumentado consideravelmente (DIEGUES, 2000). A seguir serão apresentados alguns trabalhos compreendendo a interface entre pescadores artesanais e educação ambiental.

Leal (2013) realizou um trabalho com pescadores artesanais da Lagoa de Carapebus, no Rio de Janeiro, para entender os conflitos socioambientais vividos por eles a partir da pressão sofrida por conta da implementação de áreas de proteção ambiental e de empreendimentos econômicos. A partir disso, pôde constatar a existência de certos problemas 
da comunidade referentes à autorização de pesca, à fiscalização, o desrespeito ao período do defeso e a abertura da barra que separa a lagoa do mar que, apesar de todas as dificuldades, motivaram os pescadores a se unirem e se organizarem enquanto grupo para entender seus direitos e deveres. Por outro lado, Garcia et. al. (2007), ao realizarem um trabalho sobre a educação familiar na pesca artesanal, puderam constatar que apesar dos pescadores possuírem uma visão crítica a respeito do contexto que vivem, não se mobilizam enquanto grupo para buscar mudar as adversidades experimentadas na realidade.

Bezerra (2009) realizou um trabalho com pescadores artesanais de Cáceres/MT ligados à Colônia Z-2 para conhecer as percepções dos mesmos sobre a importância do rio Paraguai e estimular a participação em ações de EA. Verificou que apesar do entendimento das adversidades vividas, os pescadores não sabem como estabelecer um canal de comunicação com as autoridades e que existe uma desconfiança por parte deles em relação às ações propostas por organizações voluntárias.

Ditty e Rezende (2013) realizaram um estudo com a comunidade de pescadores artesanais do Farol de São Tomé, no munício de Campos dos Goytacazes/RJ, para entender as percepções dos mesmos sobre o processo de decisão política referente à implantação do Complexo Portuário Industrial do Açu (ASIC), um megaprojeto que pode afetar significativamente o modo de vida da comunidade estudada. Como resultado identificaram a exclusão dos pescadores ao longo do processo de licenciamento do ASIC, demonstrando o desrespeito dos tomadores de decisão com grupos sociais que serão diretamente afetados pelo empreendimento.

Outros trabalhos (BRAVO, 2011; ANDREOLI, 2009; ANDREOLI; ANACLETO, 2006) apontam para a necessidade de integração entre conhecimentos científicos e tradicionais em busca de uma conservação ambiental eficiente que respeite a diversidade de modos de vida. Sousa et. al. (2012) apontam para a importância da educação ambiental nesse movimento de integração entre os diferentes conhecimentos. Ao realizar um trabalho para identificar as percepções de pescadores artesanais do município de Conceição do Araguaia PA constataram que o conhecimento empírico que os pescadores possuem sobre o ecossistema é de extrema importância para o adequado manejo do ambiente.

Outros autores como Souza (2012), Costa e Tagliani (2006), Pereira (2008), Perucchi, Kubo e Coelho-de-Souza (2012) também discutem a questão da organização e mobilização 
dos pescadores artesanais frisando a importância da participação e empoderamento dos mesmos.

Figueiredo (2011) constatou que apesar de pouco mais da metade das pessoas residentes na comunidade de pescadores da Ilha de Maiandeua - PA afirmarem que participam de ações de EA, ainda há um baixo envolvimento comunitário em prol da questão ambiental por não saberem como contribuir. Além disso, pôde constatar que as escolas não têm participação nas ações de EA, o que caracteriza um distanciamento entre a comunidade escolar e a comunidade como um todo.

Assim, a partir dos resultados apresentados pelos autores supracitados é possível notar que existem importantes desafios a serem enfrentados ao se trabalhar com comunidades de pescadores artesanais, como a falta de participação e mobilização nos processos de decisão, a dificuldade de se comunicar com as autoridades e a desconfiança com organizações não governamentais.

Tais desafios podem ser enfrentados e vencidos a partir dos preceitos de uma educação ambiental dialógica, como proposto nesta pesquisa, uma vez que se constitui enquanto um caminho para o surgimento de um grupo organizado e unido, que se comunica por meios dialógicos e, portanto, saberá se comunicar com diversos atores, como autoridades governamentais, ONGs, acadêmicos e outros, em busca da realização de ações transformadoras da realidade. 


\section{METODOLOGIA}

Tendo em vista os objetivos desta pesquisa, optou-se pela abordagem qualitativa, a qual permite compreender uma questão complexa de maneira profunda e detalhada (CRESWELL, 2014). Para Minayo (2002) os pesquisadores que adotam tal abordagem buscam " [...] compreender e explicar a dinâmica das relações sociais [...] [trabalhando] com a vivência, com a experiência, com a cotidianidade e também com a compreensão das estruturas e instituições como resultados da ação humana objetivada." (p. 24), considerando para isso os valores, as crenças e os hábitos vigentes.

Nesse sentido, Becker (1994) afirma que "as situações de pesquisa qualitativa incentivam, poder-se-ia dizer exigem, a improvisação [...]” (p. 14, itálico do autor), defendendo um modelo de ciência liberto da "camisa de força" de ideias metodológicas desenvolvidas em outros tempos e contextos, permitindo a adaptação metodológica às especificidades do estudo realizado pelo pesquisador, sem desconsiderar, no entanto, todo o acúmulo de conhecimento gerado por autores do passado e contemporâneos.

Dessa forma, utilizou-se o estudo de caso como inspiração epistemológica para a condução desta pesquisa, o que significa que os princípios metodológicos deste foram apropriados para a investigação sem, no entanto, se limitar a eles enquanto uma "camisa de força" (BECKER, 1994). O estudo de caso se constitui numa abordagem qualitativa, na qual o pesquisador investiga um ou mais casos da vida real por meio de múltiplas fontes de dados com o propósito de descrever em profundidade o caso estudado (CRESWEEL, 2014). O caso escolhido para este trabalho é o processo educador realizado pelo Instituto Biopesca (ONG) com pescadores artesanais, o qual é apresentado no início do item "Resultados e Discussão".

\subsection{Procedimentos de coleta e análise de dados}

Esta pesquisa foi desenvolvida em cinco etapas, descritas a seguir.

\section{Etapa 1: Revisão bibliográfica}

A pesquisa bibliográfica permite ao pesquisador entrar em contato com tudo o que já foi produzido na área de investigação que pretende se enveredar, abrangendo diversos tipos de materiais: livros, revistas, teses, gravações, filmes etc. (MARCONI; LAKATOS, 2003), sendo utilizada nesta pesquisa para cumprir o objetivo específico 1. Dessa forma, realizou-se em primeiro lugar um levantamento bibliográfico sobre o diálogo, de forma que as leituras foram realizadas ao longo de todo o período do mestrado, para entender e aprofundar as ideias 
de Martin Buber (1979; 2014), David Bohm (1980; 2005), William Isaacs (1993; 1999; 2012) e Paulo Freire (1981; 1983; 1992; 2013; e sua publicação com Ira Shor em 1986), reconhecendo suas similaridades e diferenças com o intuito de criar uma síntese, da qual emergiu um conjunto de indicadores que foram utilizados na análise dos dados.

A escolha desses autores se deu por motivos diferentes. O primeiro a ser escolhido foi Paulo Freire, devido ao forte impacto que suas ideias causam em mim, contribuindo para o entendimento e apropriação da realidade. O segundo a ser acolhido foi Martin Buber, por ter sido uma referência do próprio Freire e por seu um autor estudado no Laboratório de Educação e Política Ambiental - Oca da ESALQ/USP, do qual faço parte. Por fím, aproximei-me das ideias de David Bohm e de William Isaacs a partir da tese de Daniel Andrade, "O lugar do diálogo nas políticas públicas de educação ambiental”.

Além disso, foi realizado o aprofundamento dos aspectos históricos das organizações não governamentais e dos pescadores artesanais para identificar como o diálogo esteve, ou não, presente em suas trajetórias históricas. E, realizou-se também a revisão bibliográfica sobre educação ambiental, evidenciando sua relação com o diálogo e a concepção de EA adotada nessa pesquisa.

\section{Etapa 2: Entrevistas (semi-estruturadas)}

As entrevistas se constituem enquanto uma técnica que promove uma relação de interação entre o entrevistador e o entrevistado, permitindo "[...] a captação imediata e corrente da informação desejada, praticamente com qualquer tipo de informante e sobre os mais variados tópicos [...] [proporcionando] o tratamento de temas de natureza complexa [...]" (LUDKE; ANDRÉ, 1986, p. 34). Dentre os tipos de entrevista existentes adotou-se aqui a semi-estruturada, a qual permite ao entrevistado discorrer sobre o tema proposto, num modelo de conversa informal (BONI; QUARESMA, 2005), uma vez que o roteiro de perguntas utilizado não é aplicado de maneira rígida, permitindo explorar determinados tópicos que surjam durante a conversa ou realizar adaptações necessárias (LUDKE; ANDRÉ, 1986).

Essa técnica foi escolhida nesta pesquisa por permitir a criação de um ambiente mais descontraído entre pesquisador e entrevistado, buscando deixar os segundos mais à vontade no momento do encontro e permitindo a identificação das percepções dos atores sobre a relação vivida (objetivo específico 2), da presença ou não do diálogo em tal relação (objetivo específico 3) e das estratégias utilizadas pelos dois atores para fomentar ou não o diálogo (objetivo específico 4). 
Foram realizadas treze saídas de campo as quais resultaram na gravação de vinte e três entrevistas com o aplicativo de celular "Audio Recorder". Além disso, optou-se pela utilização de fotografias, no início das mesmas, que retratassem os diferentes momentos da relação vivida entre os atores, tendo como objetivo ativar a memória dos entrevistados, uma vez que a realização das entrevistas se deu após um período superior a um ano de término da relação entre os atores.

Vale ressaltar que as entrevistas foram realizadas com as pessoas que demonstraram interesse em participar da pesquisa, reconhecendo-se aqui os limites em relação ao acesso a todos os atores participantes do processo educador desenvolvido pela ONG com os pescadores. Eu possuía os contatos de todos os integrantes da ONG, o que não significa que todos aceitaram participar da pesquisa, e de alguns pescadores, principalmente daqueles que mantinham uma boa relação com a Organização, os quais me passaram outros contatos, incluindo de pescadores que não simpatizavam com o trabalho devolvido por aquela. Além disso, alguns pescadores foram encontrados diretamente na localidade sem nenhum tipo de contato prévio.

Dessa forma, foi possível entrevistar pessoas com diferentes visões sobre o processo vivido, de maneira que a coleta dos dados se deu até o momento em que pude verificar a repetição dos mesmos (FONTANELLA; RICAS; TURATO, 2008), sendo possível realizar uma análise em direção aos objetivos propostos nesta pesquisa, mas reconhecendo que não se esgotaram todas as possibilidades. Ademais, é importante destacar que as identidades dos sujeitos entrevistados foram resguardadas, recebendo um nome genérico e um número, exemplo: Integrante 3 da ONG; Pescador 7.

Outro ponto a destacar foi a realização de um pré-teste do roteiro de perguntas com um pescador do município de Praia Grande/SP e um integrante da ONG, a partir do qual foi possível verificar a necessidade de incorporar mais questões, passando a ser composto por perguntas sobre o cumprimento e a importância dos objetivos propostos do Projeto; o que se esperava dele; como era a relação entre os atores a partir das conversas, dos encontros do diagnóstico participativo, dos cursos e do concurso; as percepções que um ator tinha do outro; a existência de conflitos; a existência de ações planejadas e executadas conjuntamente. Optouse, portanto, pela estruturação do roteiro de forma a começar com perguntas amplas para "aquecer" a conversa, migrando posteriormente para questões detalhadas (LUDKE; ANDRÉ, 1986). Apesar desse incremento feito ao roteiro, os dados coletados no pré-teste foram considerados nas análises. 
Das vinte e três entrevistas, seis foram realizadas com integrantes da ONG, dentre eles membros da coordenação, da equipe de monitoramento de capturas acidentais, da equipe de educação ambiental e da equipe de comunicação. Apesar de haver uma distinção nominal entre as equipes, estando a EA restrita aparentemente à uma delas, entende-se aqui que todos os integrantes da ONG contribuíam para o processo de EA desenvolvido e, portanto, buscouse entrevistar aqueles que tiveram contato direto com os pescadores.

As dezessete entrevistas restantes foram realizadas com pescadores de cinco municípios: Peruíbe (3), Itanhaém (3), Mongaguá (5), Praia Grande (2) e São Sebastião (4). Dessa forma, quatro municípios da área de abrangência do Projeto da ONG foram excluídos desta pesquisa: Santos por ter se constituído numa exceção feita pela ONG, uma vez que os pescadores dessa área são industriais e nesta pesquisa se considerou apenas os artesanais marítimos; São Vicente por não ter recebido o Projeto devido à problemas com a segurança da equipe; e Guarujá e Bertioga por não ter sido possível encontrar pescadores dispostos a participar da pesquisa.

Para a transcrição das entrevistas foi utilizado o software Express Scribe Transcription, o qual permite a utilização de comandos no teclado que auxiliam a fluidez do processo. A primeira etapa desse momento se caracterizou pela transcrição das falas dos entrevistados em documento Word, destacando além das entonações, os sinais não-verbais sempre que possível, uma vez que as entrevistas gravadas não permitem o registro dos mesmos (LUDKE; ANDRÉ, 1986), contando para isso com o auxílio de um caderno de campo no qual foram anotados os aspectos que chamaram a atenção durante a entrevista, imediatamente após a realização da mesma, e com a memória do entrevistador. Além disso, à medida que as entrevistas eram transcritas, realizaram-se anotações em forma de comentários quando se identificava indícios do diálogo ou do não diálogo, constituindo-se numa primeira análise dos dados. A segunda etapa desse processo compreendeu uma nova escuta das entrevistas, objetivando revisar a primeira transcrição e iniciar a organização dos dados.

\section{Etapa 3: Análise de documentos}

A pesquisa documental consiste na coleta de dados presentes em documentos, escritos ou não, entendidos como fontes primárias (MARCONI; LAKATOS, 2003), sendo “[...] uma fonte poderosa de onde podem ser retiradas evidências que fundamentem afirmações e declarações do pesquisador" (LUDKE; ANDRÉ, 1986, p. 39), além de complementar os dados obtidos por outras técnicas (LUDKE; ANDRÉ, 1986). Para tal, foram considerados o 
projeto da ONG aprovado em edital no ano de 2012 e os dezoito relatórios enviados ao patrocinador ao longo de todo o projeto.

A análise de documentos nesta pesquisa foi realizada com o intuito de complementar os dados coletados nas entrevistas, visando contribuir para o cumprimento dos objetivos específicos 3 e 4. Primeiro foi feita uma leitura flutuante (BARDIN, 1979), caracterizada por um primeiro contato com os documentos em que emergem as primeiras impressões sobre o mesmo, buscando identificar os pressupostos-base da ONG, a concepção de EA adotada, as metas para cada atividade, bem como identificar indícios do diálogo. Para isso, foram analisados tanto a parte escrita como as imagens (fotografias) e tabelas apresentadas nos documentos, realizando comentários nas margens dos mesmos. Por fim, foi realizada uma leitura mais profunda visando encontrar indícios que pudessem ter escapado da primeira leitura.

\section{Etapa 4: Análise dos dados}

Como foi possível observar nas etapas anteriores, a análise dos dados foi iniciada durante a transcrição das entrevistas e leitura dos documentos, buscando identificar nas frases/parágrafos, nas fotografias e nas tabelas aspectos do diálogo e do antidiálogo presentes nos diferentes momentos da relação, a partir de três categorias de análise criadas com base nas ideias de Bohm (2005), Isaacs (1999) e Freire (1981; 1983) (aspectos externos, aspectos internos e ação dialógica), cada qual com um conjunto de perguntas-indicadoras (como consta no Quadro 1 da página 49).

A partir disso, foi feita uma primeira análise em separado dos dados coletados por meio das duas técnicas supracitadas, buscando organizá-los e interpretá-los de acordo com as categorias estabelecidas. Em seguida, procedeu-se a comparação dos dados encontrados em cada técnica com o propósito de identificar similaridades e contradições, interpretando-as com base no Quadro 1. Além disso, buscou-se, sempre que possível, apresentar depoimentos de três ou mais atores a respeito de algum aspecto da relação, evidenciando as concordâncias ou discordâncias sobre determinado aspecto.

\section{Etapa 5: Devolutiva para os participantes da pesquisa}

Os resultados da pesquisa serão sintetizados em linguagem apropriada para que se faça a devolutiva para os atores que participaram das entrevistas. 


\section{RESULTADOS E DISCUSSÃO}

Nesta seção será apresentada uma caracterização do Projeto desenvolvido pela ONG Instituto Biopesca com pescadores artesanais, considerando todas as atividades realizadas enquanto etapas de um processo educador ambientalista e, em seguida, serão apresentados os resultados encontrados e discutidos segundo o referencial teórico aqui adotado.

\subsection{Caracterização do processo educador promovido pelo Instituto Biopesca}

O Instituto Biopesca atua, desde 1998, na conservação marinha de espécies de animais ameaçados de extinção, em especial a espécie de golfinho toninha (Pontoporia blainvillei) e as tartarugas marinhas, dando início, em agosto de 2013, ao Projeto Pescador Amigo aprovado no edital Petrobras Ambiental, da empresa Petrobras, tendo seu fim em agosto de 2015 (INSTITUTO BIOPESCA, 2012).

Com o início de tal Projeto a ONG pôde expandir suas ações, até então restritas ao município de Praia Grande/SP, município sede da instituição, e a algumas ações desenvolvidas em outros municípios, como Ubatuba. A partir de então o trabalho passou a ser realizado nos municípios costeiros do litoral central de São Paulo (Peruíbe, Itanhaém, Mongaguá, Praia Grande, Santos, São Vicente, Guarujá e Bertioga) (INSTITUTO BIOPESCA, 2012), sendo mais tarde incorporada a região sul de São Sebastião. O objetivo geral do Projeto consistia em:

Monitorar e ampliar o conhecimento do impacto das capturas acidentais de golfinhos e tartarugas marinhas no litoral central do Estado de São Paulo, bem como sensibilizar e capacitar pescadores, comunidades costeiras e turistas com ações de educação ambiental, com foco para práticas de pesca responsável, consumo consciente de pescado e a importância da preservação do ambiente marinho. (INSTITUTO BIOPESCA, 2012, p. 8).

Acompanhando esse objetivo geral estavam seis objetivos específicos (INSTITUTO BIOPESCA, 2012), são eles:

1) Ampliar o conhecimento sobre as espécies de golfinhos e tartarugas marinhas acidentalmente capturadas.

2) Monitorar e avaliar o impacto das capturas acidentais de golfinhos e tartarugas marinhas no litoral central de São Paulo.

3) Capacitar os pescadores sobre as práticas de pesca responsável e sensibilizar, por meio de exposições e palestras, as comunidades costeiras e turistas sobre importância de preservação do ambiente marinho.

4) Realizar atividades de educação ambiental objetivando gerar conhecimento sobre o ambiente marinho e a importância da sua preservação para crianças e adolescentes da Rede Pública de Ensino. 
5) Realizar concurso para pescadores dos municípios abrangidos pelo projeto visando estimular o desenvolvimento de novas tecnologias, práticas e condutas de pesca responsável.

6) Incentivar o consumo consciente de pescados por meio do Guia de Consumo Responsável de Pescado. (p. 8).

Cada objetivo específico era composto por um conjunto de atividades que foram desenvolvidas ao longo de seis quadrimestres, destacando-se aqui aquelas realizadas pelas equipes de monitoramento de captura acidental e de educação ambiental, as quais possuíam contato direto com os pescadores.

As atividades de pesquisa consistiam no monitoramento das localidades pesqueiras por uma equipe da ONG, com o intuito de recolher os animais capturados acidentalmente pelos pescadores, que vieram a óbito, para coletar e analisar amostras biológicas. Esse trabalho demandava o sentimento de confiança entre os dois conjuntos de atores para ocorrer, já que a captura e o transporte de tais animais são proibidos pela legislação ambiental brasileira. No entanto, a ONG possuía o respaldo de uma Instrução Normativa que permite o transporte dos animais mortos para fins de pesquisa. Após recolhidos, os animais eram encaminhados para o laboratório para a coleta de amostras biológicas (INSTITUTO BIOPESCA, 2012).

As atividades de educação ambiental se baseavam na concepção crítica da EA, a qual se fundamenta nos princípios democráticos e emancipatórios rompendo com a educação tecnicista e replicadora de conhecimentos prontos, buscando a construção social do conhecimento a partir de temas geradores, como preconiza Paulo Freire em suas obras, almejando estabelecer uma ligação entre a realidade dos educandos e o conhecimento a ser construído, fato que estimula o exercício de um olhar crítico sobre a realidade vivida e permite a emancipação e autonomia dos sujeitos participantes do processo educativo (CARVALHO, 2004). Tal concepção foi adotada com o objetivo de tratar da problemática das capturas acidentais e promover a ideia da pesca responsável. Para isso, possuíam como público-alvo estudantes de escolas públicas municipais, turistas e pescadores (INSTITUTO BIOPESCA, 2012; 2014c). A seguir será apresentado o processo de planejamento e execução dessas atividades.

O início do trabalho foi marcado pelo planejamento das atividades de educação ambiental a serem desenvolvidas nas escolas públicas e pela realização das articulações institucionais com diferentes atores - polícia ambiental, bombeiros, gestores de unidades de conservação, defesa civil, colônia de pesca, prefeituras, secretarias de meio ambiente e outros, 
do litoral central do Estado de São Paulo para apresentar o Projeto e conseguir apoio por meio de parcerias (INSTITUTO BIOPESCA, 2013).

No segundo quadrimestre (dezembro/2013 a março/2014) foram realizadas as primeiras exposições "Pesca Responsável” que se estenderam até o final do Projeto, atingindo 5.395 pessoas. Consistiam em ações pontuais realizadas em escolas e eventos, como Semana do Meio Ambiente, onde eram expostos: painéis infográficos com informações sobre pesca e captura acidental; réplicas em tamanho real de toninha e tartaruga verde; material biológico, como fetos de toninha, arcada dentária de tubarão, barbatana de baleia, cascos de tartarugas e outros (INSTITUTO BIOPESCA, 2014a; 2015e).

Nesse mesmo período teve início o Programa de Educação Ambiental Continuada (PEAC) que se estendeu até o quarto quadrimestre. Este programa atingiu 856 alunos da rede municipal de ensino de Santos/SP e Praia Grande/SP (INSTITUTO BIOPESCA, 2014b; 2015e). A primeira etapa do Programa consistia na realização de palestras com os professores que participariam do PEAC, com o propósito de se constituir num primeiro contato com as escolas e de permitir a participação dos professores no Projeto, sugerindo contribuições (INSTITUTO BIOPESCA, 2014b).

O PEAC era constituído inicialmente por cinco encontros presenciais com cada turma de quarto e quinto ano da escola trabalhada e uma saída de campo (vivência) para a comunidade pesqueira de Praia Grande/SP. Cada um dos cinco dias compreendia atividades pedagógicas com duas horas de duração equivalente a um eixo temático, sendo eles: “Ecossistemas Marinhos e Costeiros"; "Baleias e Golfinhos"; "Tartarugas Marinhas”; "Pesca Sustentável” e "Consumo Responsável” (INSTITUTO BIOPESCA, 2014c). Posteriormente, por uma questão de tempo, foi preciso reduzir para dois encontros presenciais, tendo então apenas dois eixos temáticos, "O ambiente marinho, toninhas e tartarugas marinhas" e "Pesca Responsável”, e a saída de campo (INSTITUTO BIOPESCA, 2014d).

Avançando um pouco no tempo, terceiro quadrimestre (abril/2014 a julho/2014), foi iniciado o Programa de Ação de Sensibilização Ambiental (PASA) criado para levar a exposição "Pesca Responsável" para pelo menos duas escolas de cada município da área de abrangência do Projeto. O PASA ocorreu até o último quadrimestre do Projeto e atingiu 7.741 crianças e adolescentes (INSTITUTO BIOPESCA, 2014e; 2015e; 2015g). O Programa funcionava da seguinte maneira: eram agendadas visitas na escola de um dia de duração, onde a exposição "Pesca Responsável” ficava aberta para toda a comunidade escolar visitar e trocar informações com a equipe de EA (INSTITUTO BIOPESCA, 2014e; 2015g). 
As atividades de EA com os pescadores tiveram início no terceiro quadrimestre com um conjunto de atividades, sendo concluída somente no final do projeto e atingindo 574 pescadores (INSTITUTO BIOPESCA, 2014f; 2015a). O objetivo era o de sensibilizar e capacitar os pescadores artesanais da área de abrangência do Projeto sobre práticas de pesca responsável, de acordo com os princípios do Código de Pesca Responsável elaborado pela FAO em 1995 (INSTITUTO BIOPESCA, 2012; 2014g). Inicialmente estava previsto apenas um curso para os pescadores artesanais da área de abrangência do Projeto, mas isso mudou ao longo do mesmo.

Uma etapa preliminar do trabalho com os pescadores consistiu na realização de entrevistas para entender um pouco mais a comunidade, apresentar a equipe de EA para os pescadores e identificar o interesse dos mesmos em participar de futuros encontros. Importante salientar que todas as atividades realizadas pela equipe de EA com os pescadores contaram com o apoio da equipe de monitoramento de capturas acidentais (INSTITUTO BIOPESCA, 2014f).

Após esse primeiro momento se decidiu realizar um diagnóstico sobre a situação da pesca juntamente com os pescadores. Dessa forma, passou-se a ter três ações que ocorreram de maneira sequencial em cada localidade pesqueira: $1^{a}$ ) Diagnóstico Participativo; $2^{a}$ ) Curso sobre Empreendedorismo Sustentável; $3^{\mathrm{a}}$ ) Curso sobre Práticas de Pesca Responsável (INSTITUTO BIOPESCA, 2014f; 2014g).

O diagnóstico participativo ocorreu por meio da utilização de uma metodologia intitulada Biomapa (INSTITUTO ECOAR PARA A CIDADANIA, 2008) com o propósito de responder a duas perguntas: “a) Como melhorar a pesca na região? b) Qual seria o cenário ideal da pesca local?" (INSTITUTO BIOPESCA, 2014f; 2014g).

Finalizada a etapa do diagnóstico foi iniciado o Curso sobre Empreendedorismo Sustentável, com quatro horas de duração, compreendendo uma apresentação sobre a situação da pesca no Mundo, no Brasil e no Estado de São Paulo, a problemática da captura acidental e o Código de Conduta para a Pesca Responsável da FAO realizada pela equipe do Projeto e uma palestra do Sebrae sobre empreendedorismo sustentável. Nesta etapa cada participante do curso ganhou um kit composto por ecobag, boné, camiseta, bloco de notas, caneta e adesivo e o grupo ganhou um mural para facilitar a comunicação entre a ONG e os pescadores. Além disso, todos os participantes receberam certificado de participação (INSTITUTO BIOPESCA, 2014g). 
O Curso sobre Práticas de Pesca Responsável, realizado após o curso sobre empreendedorismo, foi ministrado pelos membros da ONG, com uma duração que variou de trinta minutos a uma hora a depender da localidade e consistia na apresentação de algumas práticas de pesca responsável, divulgação do Concurso de Práticas e Tecnologias de Pesca Responsável e numa avaliação coletiva sobre o Projeto, por meio da evocação de palavras e em alguns casos discurso livre. Nesta etapa não foram entregues certificados de participação (INSTITUTO BIOPESCA, 2014g; 2015a).

No sexto quadrimestre foram finalizadas todas as atividades merecendo destaque o Concurso de Práticas e Tecnologias de Pesca Responsável. A proposta era a de estimular os pescadores a divulgarem suas práticas de pesca ou ideias sobre novas práticas que contribuíssem para a diminuição da captura acidental. As três melhores ideias foram premiadas num evento e enviadas para o Ministério da Pesca e Aquicultura e Ministério do Meio Ambiente (INSTITUTO BIOPESCA, 2015b; 2015c; 2015d).

\subsection{Aspectos externos}

Para análise dos aspectos externos (número de participantes envolvidos, disposição dos mesmos durante o encontro, frequência dos encontros e local do encontro) foram consideradas as diferentes formas de contato entre os atores: as conversas durante as visitas de monitoramento de captura acidental; as conversas para convidar os pescadores a participar dos encontros de educação ambiental; os diagnósticos participativos; os cursos sobre empreendedorismo sustentável; os cursos sobre práticas de pesca responsável; e o concurso de práticas e tecnologias de pesca responsável (INSTITUTO BIOPESCA, 2014f; 2014g; 2014h; 2014i; 2014j; 2015a; 2015c; 2015d; 2015e; 2015f).

\subsubsection{Conversas}

As conversas se caracterizaram pelo encontro entre integrantes da ONG, da equipe de monitoramento de capturas acidentais e da equipe de educação ambiental, com os pescadores. A equipe de monitoramento era a que possuía maior constância nos encontros, uma vez que o monitoramento compreendia visitas constantes às localidades pesqueiras. Já a equipe de EA foi ao encontro dos pescadores em momentos que antecediam os encontros de educação ambiental com o propósito de convidá-los a participar, portanto, com um caráter mais pontual (INSTITUTO BIOPESCA, 2014f; 2014h; 2014i; 2015f). 
As conversas possuíam uma frequência semanal, de forma que cada localidade era visitada uma vez por semana pelos monitores de captura acidental (INSTITUTO BIOPESCA, 2014i; 2015f), o que vai ao encontro do proposto por Bohm (2005) sobre a importância de encontros regulares para a emergência do diálogo. Ele afirma que "as pessoas precisam se encontrar com regularidade [...] semanalmente, ou de quinze em quinze dias, e manter-se assim por um longo tempo - um ano, dois anos ou mais." (p. 48).

O número de atores envolvidos nas conversas variava de duas a seis pessoas, tendo diferentes configurações em relação aos integrantes da ONG e pescadores presentes: um integrante da ONG e um pescador; dois integrantes da ONG e um pescador; um integrante da ONG e três pescadores; um integrante da ONG e quatro pescadores etc. (INSTITUTO BIOPESCA, 2014h; 2014f; 2015f).

É possível notar que o número de envolvidos nas conversas está distante do sugerido por Bohm (2005). Para o autor é possível dialogar com uma, duas, três pessoas ou até consigo mesmo, no entanto, é num grupo de vinte a quarenta pessoas que se permite a emergência do microcosmo da cultura global, pois se tem indivíduos de diferentes subculturas e, portanto, as contradições vividas pela sociedade conseguem emergir.

Nesse sentido, o autor alerta que num grupo menor tal fato não acontece, chamando a atenção para o que costuma ocorrer numa conversa entre seis pessoas, número máximo de envolvidos nas conversas entre ONG e pescadores: "Se seis indivíduos se reúnem, eles em geral se ajustam mutuamente de modo a não dizer coisas que contrariem uns aos outros chegam a um 'ajuste confortável'.” (BOHM, 2005, p. 44).

A disposição dos participantes nas conversas foi bastante variada assumindo diversas formas (Figura 3). Foi possível verificar a disposição de duas a três pessoas em linha reta, de três e quatro pessoas em triângulo, de quatro pessoas em retângulos, de três, quatro e cinco pessoas em semicírculos em volta dos petrechos de pesca e círculo de seis pessoas (INSTITUTO BIOPESCA, 2014h; 2014f; 2015f). O formato circular é o sugerido para promover a emergência do diálogo, já que promove a horizontalidade entre os participantes (BOHM, 2005; ISAACS, 1999; FREIRE 1981), no entanto, não há indícios de que o triângulo com três pessoas ou o retângulo formado por quatro pessoas tenham desfavorecido a horizontalidade, criando privilégios para alguns dos atores (BOHM, 2005; ISAACS, 1999). Por outro lado, no triângulo de quatro pessoas e na linha de três pessoas a situação é diferente, pois nessas duas configurações três pessoas ficam lado a lado, impedindo o contato visual 
entre todos e, portanto, ferindo a horizontalidade dialógica sugerida por Bohm (2005), Isaacs (1999) e Freire (1981).

Figura 3 - Disposição dos atores nas conversas

\begin{tabular}{|c|c|}
\hline NÚMERO DE PESSOAS & DISPOSIC̣ÃO \\
\hline 2 pessoas (lado a lado ou frente a frente) & • \\
\hline \multirow{3}{*}{3 pessoas } & \\
\hline & ○ \\
\hline & Potrecho do Puca \\
\hline \multirow{5}{*}{4 pessoas } & \\
\hline & Potrecho do Pusca \\
\hline & \\
\hline & \\
\hline & Perrecho do Porca \\
\hline \multicolumn{2}{|l|}{5 pessoas } \\
\hline 6 pessoas & $\bullet$ \\
\hline
\end{tabular}

Fonte: desenvolvida pelo autor dessa pesquisa com base nos dados coletados dos documentos do INSTITUTO BIOPESCA (2014f; 2014h; 2014i; 2015f).

Outro ponto importante é que os locais das conversas eram aqueles ocupados cotidianamente pelos pescadores: as praias, as peixarias (INSTITUTO BIOPESCA, 2014h; 2014f), o trapiche (INSTITUTO BIOPESCA, 2014h) ou até mesmo na casa do pescador (INSTITUTO BIOPESCA, 2015f). A importância do local, como colocado por Isaacs (1999), 
está ligada à acústica do mesmo, de forma a permitir que todos se escutem e que não existam muitos elementos que possam tirar a concentração dos participantes durante a conversa.

Nesse sentido, as praias e os trapiches parecem não atender às exigências do autor. Estes locais são ambientes abertos, às vezes com bastante vento, o que pode dificultar a escuta. Além disso, alguns pescadores conversavam com os integrantes da ONG enquanto trabalhavam (INSTITUTO BIOPESCA, 2014f; 2015f) o que impede a atenção genuína na conversa. Sobre as peixarias e as casas dos pescadores não é possível afirmar com certeza se possuíam boa acústica e disposição adequada para a emergência do diálogo, já que não há registros nos documentos da ONG e nem nas falas dos entrevistados sobre essa questão.

\subsubsection{Encontros de educação ambiental}

\subsubsection{Diagnósticos participativos}

Os encontros para a realização dos diagnósticos participativos entre pescadores e ONG tiveram duração de duas horas e ocorreram por meio da construção de biomapas, “[...] o qual consiste em uma ferramenta de diagnóstico participativo de uma realidade a partir da visão das pessoas que o elaboram, com o objetivo de apontar os principais problemas e potencialidades para em seguida elaborar planos de ação.” (INSTITUTO BIOPESCA, 2014g, p. 3). Os objetivos da ONG com tais encontros eram: "elencar os principais problemas dos pescadores artesanais em relação à realidade pesqueira local; criar planos de ação em resposta aos problemas identificados; estimular a participação, o sentimento de pertença e a autonomia nos participantes" (INSTITUTO BIOPESCA, 2014g, p. 2).

Nesses encontros a disposição predominante foi o semicírculo, uma vez que se utilizou de flipchart para a confecção do biomapa, o qual ficou posicionado de forma que todos os participantes pudessem visualizá-lo. Apenas em duas localidades, as quais contaram com poucos participantes (três pescadores em uma e quatro em outra), foi formada uma roda em volta de uma mesa, na qual se apoiou o biomapa (INSTITUTO BIOPESCA, 2014f; 2014g). Dessa forma, é possível verificar o atendimento à disposição estimuladora do diálogo sugerida por Bohm (2005), Isaacs (1999) e Freire (1981).

Além disso, os locais escolhidos para esses encontros foram os já citados no subitem "Conversas": a praia, as peixarias, casa de pescador ou até mesmo a feira de artesanato local, a qual se caracterizava por um ambiente aberto sujeito aos mesmos desafios em termos de acústica dos locais supracitados (INSTITUTO BIOPESCA, 2014f; 2014g). Assim, as considerações já realizadas no subitem anterior também se aplicam nesse caso. 
Sobre o número de pessoas envolvidas em tais encontros não foi possível analisar com certeza, uma vez que os registros que se têm consideram apenas o número de pescadores presentes, variando de três a vinte e cinco por encontro, não contabilizando a equipe da ONG. Recordo-me que o número de integrantes da ONG era variável, uma vez que contávamos com a presença de integrantes das equipes de monitoramento de capturas acidentais, de educação ambiental, da comunicação e do motorista.

Em relação à frequência de tais encontros foi possível verificar o caráter pontual de tal ação, já que cada localidade pesqueira contou com apenas uma reunião para a realização do diagnóstico participativo, não tendo o detalhamento do planejamento, nem a execução e a avaliação de uma ação conjunta com base nas demandas dos pescadores diagnosticadas, como fica claro no item "Ação dialógica", a partir dos depoimentos dos pescadores e dos integrantes da ONG. A única exceção foi a localidade de Boissucanga/São Sebastião em que se deu um pequeno passo a mais nesse processo. Os pescadores dessa localidade solicitaram um encontro para se conversar sobre turismo de base comunitária, o qual foi arranjado pela ONG. No entanto, não houve depois disso novos encaminhamentos para a ação (INSTITUTO BIOPESCA, 2014f; 2014g).

Apesar da pontualidade, os diagnósticos se caracterizaram por uma aproximação de pedagogias dialógicas, haja vista que a metodologia adotada busca estimular a emergência de um encontro marcado pela troca entre os participantes, superando a transmissão de saberes, característica das pedagogias tradicionais antidialógicas, como sugere Freire (1981; 1983), o que mostra uma potencialidade importante em termos de diálogo.

\subsubsection{Cursos sobre Empreendedorismo Sustentável}

O Curso "Empreendedorismo sustentável" teve duração de quatro horas e se caracterizou pela apresentação da ONG sobre

[...] o histórico da atividade e produção pesqueira no mundo, no Brasil e no Estado de São Paulo, enfatizando o conceito de sobrepesca (pesca excessiva) e da queda da produção dos principais recursos pesqueiros. [Além disso] $\mathrm{O}$ Código de Práticas de Pesca Responsável, criado em 1995 pela FAO, o qual apresenta diretrizes para que a pesca e suas atividades sejam realizadas de forma sustentável foi apresentado aos pescadores, enfatizando seis princípios que abordam a exploração sustentável dos recursos pesqueiros [...]. Após a apresentação da aula ministrada pela equipe do Projeto, os pescadores participaram da aula ministrada pela consultora do Sebrae [...] que iniciou sua apresentação com uma dinâmica que estimula os participantes a pensarem no comportamento de tomada de iniciativa. Na sequência a consultora do Sebrae conceituou os 10 comportamentos empreendedores e 
apresentou o conceito de empreendedorismo sustentável [...] (INSTITUTO BIOPESCA, 2014g, p. 10).

O arranjo do espaço em tais momentos foi marcado pela disposição dos participantes em fileiras, de forma que os mesmos ficaram voltados para uma pessoa portadora da fala, no caso os integrantes da ONG e a consultora do Sebrae (INSTITUTO BIOPESCA, 2014g; 2014j). Tal disposição representa o oposto do que suscita o círculo, criando uma hierarquia entre os participantes e impedindo que todos tivessem a mesma oportunidade de fala, como sugerem Bohm (2005), Isaacs (1999) e Freire (1981).

Assim como nos encontros do diagnóstico participativo aqui não foi possível precisar com exatidão o número de participantes por não haver registro do número de membros da equipe da ONG presentes no encontro. Além disso, sobre a frequência dos encontros do curso é possível afirmar que também possuiu um caráter pontual, haja vista que cada localidade foi contemplada com uma visita de quatro horas. Quanto aos locais, foram os mesmos já citados para os encontros do diagnóstico participativo (INSTITUTO BIOPESCA, 2014j; 2015a), valendo novamente as mesmas considerações já feitas.

Dessa forma, a escolha do modelo de palestra em que os participantes se encontram dispostos em fileiras, com o objetivo de transmitir informações indica a adoção de uma proposta pedagógica antidialógica, uma vez que tal formato de encontro estabelece uma hierarquia no poder de fala e adota a perspectiva de transmissão de informações, dois aspectos obstaculizadores do diálogo (BOHM, 2005; ISAACS, 1999; FREIRE, 1981; 1983).

O estabelecimento da hierarquia no poder de fala se contrapõe a horizontalidade necessária para a emergência e manutenção do diálogo, na qual todos os participantes têm a oportunidade de enunciar seus significados e de ouvir os significados dos outros (BOHM, 2005; ISAACS, 1999). A transmissão de informações, por sua vez, implica na perspectiva de extensão criticada por Freire (1981; 1983), na qual se busca estender os conhecimentos técnicos às pessoas que não os possuem.

\subsubsection{Cursos sobre Práticas de Pesca Responsável}

O Curso sobre Práticas de Pesca Responsável teve uma duração que variou conforme a localidade, de trinta minutos a uma hora, e tinha como objetivo "[...] o resgate dos principais conceitos trabalhados [no Curso sobre Empreendedorismo Sustentável] e a discussão de algumas práticas de pesca responsável, bem como a divulgação do Concurso de Práticas e Tecnologias de Pesca Responsável.” (INSTITUTO BIOPESCA, 2015a, p. 1). 
A disposição predominante dos participantes em tais encontros foi o semicírculo durante a apresentação de slide, seguida por rodas de conversa e, portanto, contando com a disposição circular dos participantes (INSTITUTO BIOPESCA, 2015a). Aqui também há a impossibilidade de saber ao certo o número de participantes presentes, pelo mesmo motivo dos outros encontros. Além disso, os locais desses momentos foram os mesmos dos encontros anteriores e em relação à frequência valem as mesmas considerações já feitas sobre o diagnóstico participativo e sobre o curso sobre empreendedorismo (INSTITUTO BIOPESCA, 2015a).

Assim, esses encontros parecem ter se caracterizado por uma proposta pedagógica que se aproximou mais daquela utilizada nos cursos sobre empreendedorismo sustentável, obstaculizadora do diálogo, do que da utilizada nos diagnósticos participativos, estimuladora da emergência dialógica. Aqui se proporcionou uma participação maior do que no primeiro curso dos pescadores, os quais puderam discutir junto com os integrantes da ONG algumas práticas de pesca responsável. No entanto, tal discussão se caracteriza por um modelo de conversa que implica em ideias vencedoras e ideias perdedoras, não acolhendo a diversidade e, portanto, sendo contrária aos princípios dialógicos. Além disso, a discussão foi pautada pelos pressupostos da ONG sobre Pesca Responsável, não havendo indícios de abertura às demandas dos pescadores e, portanto, do exercício da suspensão (BOHM, 2005; ISAACS, 1999).

\subsubsection{Concurso de Práticas e Tecnologias de Pesca Responsável}

O Concurso de Práticas e Tecnologias de Pesca Responsável foi elaborado com o propósito de estimular os pescadores a contribuírem com ideias para diminuir ou evitar a captura acidental de golfinhos e tartarugas marinhas, sendo as três melhores ideias premiadas (INSTITUTO BIOPESCA, 2015c; 2015d; 2015e). Para isso, foi criado um edital que foi divulgado pela equipe de monitoramento de capturas acidentais da ONG para os pescadores durante as conversas semanais. Dessa forma, as considerações sobre os aspectos externos são as mesmas já realizadas no subitem "Conversas”, não sendo necessário repeti-las.

Nesse sentido, apesar da intenção de integração entre conhecimento científico e tradicional pela ONG, a qual pode ser considerada uma potencialidade dialógica, não há indícios de que as conversas entre os atores sobre o concurso de fato suscitaram tal integração, uma vez que, para não haver favoritismo, a ONG não aprofundava muito o tema, assumindo a postura de divulgar o concurso e estimular os pescadores a participarem. 
Além disso, a lógica competitiva do concurso parece ter sido um meio contraditório para se atingir o objetivo proposto. A competitividade traz consigo a forte marca da segregação e do individualismo, além de hierarquizar as ideias com base nos pressupostos da própria ONG, haja vista que esta julgou as melhores ideias a serem premiadas. Portanto, o concurso se caracterizou por aspectos potencialmente obstaculizadores do diálogo (BOHM, 2005; FREIRE, 1981).

\subsubsection{Considerações sobre os aspectos externos}

A partir do exposto acima foi possível notar indícios que obstaculizam e outros que potencializam a emergência do campo relacional do diálogo, em relação aos aspectos externos, nos diferentes momentos de contato entre os atores.

Em relação aos locais em que os encontros se deram os indícios encontrados apontam para a obstaculização do diálogo, já que as praias e trapiches são ambientes abertos e com vento, o que pode dificultar a escuta. Além disso, o fato de alguns pescadores trabalharem enquanto conversavam com os integrantes da ONG indica a falta de foco no encontro, o que para Isaacs (1999) é algo fundamental para a emergência do diálogo.

Sobre a disposição dos participantes houve momentos em que se adotaram formatos obstaculizadores do diálogo e outros que foram marcados por formatos potencializadores do mesmo. Nas conversas os formatos foram variados, sendo possível observar disposições que potencializam o diálogo, como o semicírculo e o círculo, e disposições que o obstaculizam como as linhas de três pessoas e o triangulo de quatro pessoas. Nos encontros do diagnóstico participativo e do curso sobre práticas de pesca responsável houve a predominância da disposição em semicírculo e círculo, o que potencializa a emergência do campo dialógico. Por outro lado, a predominância de fileiras no curso sobre empreendedorismo sustentável se constitui enquanto um forte obstáculo para a emergência do diálogo, uma vez que se reforça a hierarquia daquele(a) que fala e impede que todos se vejam.

Sobre a frequência dos encontros entre os atores é possível analisar de duas formas. $\mathrm{Na}$ primeira, considerando a constância dos encontros entre os atores a partir de diferentes formatos, as conversas semanais entre equipe de monitoramento de captura acidental e pescadores, sendo intercaladas com os encontros de educação ambiental, apresentam a regularidade sugerida por Bohm (2005). Na segunda, considerando tais formatos separadamente, as conversas tiveram sua constância conforme as ideias de Bohm (2005), mas os encontros de EA, por sua vez, apresentaram um caráter pontual, já que foram realizados 
apenas três encontros em cada localidade ao longo dos dois anos de contato entre os atores. $\mathrm{O}$ caráter pontual é reforçado pelo fato de os cursos terem uma pequena carga horária, quatro horas para o curso sobre empreendedorismo e de trinta minutos a uma hora para o curso sobre práticas de pesca responsável (INSTITUTO BIOPESCA, 2014g; 2015a), o que mostra o pouco tempo de contato entre os atores para se aprofundarem em questões de interesse. Além disso, outro aspecto que denota tal caráter pontual, não frequente, é o espaço de tempo entre esses encontros, o qual variou de um a quatro meses entre o diagnóstico participativo e o curso sobre empreendedorismo, dependendo da localidade, e de seis a sete meses entre este último e o curso sobre práticas de pesca responsável, a depender da localidade (INSTITUTO BIOPESCA, 2015a).

Além disso, é possível perceber que os encontros foram marcados por estratégias pedagógicas antagônicas. Os diagnósticos participativos se aproximaram bastante dos princípios e valores presentes no Tratado de Educação Ambiental para Sociedades Sustentáveis e Responsabilidade Global (FÓRUM GLOBAL DAS ONGS, 1992) e de uma pedagogia dialógica (ANDRADE; SORRENTINO, 2014a; 2014b), já que estimularam a participação ativa dos sujeitos, o reconhecimento das contradições vividas e o reconhecimento do Outro, sendo um primeiro passo importante para o desvelamento dos aspectos históricoculturais.

O curso sobre práticas de pesca responsável, apesar de adotar a disposição circular e permitir uma interação entre os atores estava pautado nos princípios da discussão, contrários ao diálogo (BOHM, 2005), e nos pressupostos da ONG referentes à Pesca Responsável (FOOD AND AGRICULTURE ORGANIZATION OF THE UNITED NATIONS, 1995), não havendo indícios de uma abertura às demandas dos pescadores, o que dificulta o exercício de desvelamento das contradições histórico-culturais vividas por eles (FREIRE, 1981).

O curso sobre empreendedorismo, por sua vez, adotou uma concepção pedagógica conservadora (ANDRADE; SORRENTINO, 2014a), visando transmitir informações para os pescadores, estendendo o conhecimento técnico para eles de forma hierárquica (FREIRE, 1983) e, portanto, caracterizando-se pela antidialogicidade.

Outro aspecto relevante, para além do diálogo, de processos de educação ambiental que promovam a transição para sociedades sustentáveis (FORUM GLOBAL DAS ONGs, 1992) é seu caráter continuado e articulado (BRASIL, 1999), o qual não parece ter sido atendido, já que os diagnósticos participativos não tiveram continuidade, desdobrando-se em ações coletivas para compreender e transformar a realidade vivida. Além disso, não foram 
encontrados indícios de que havia uma articulação entre os encontros de diagnóstico e os cursos, de forma que os primeiros parecem ter ficado isolados no tempo. Isso se confirma na fala da coordenação da ONG, quando coloca que não possui conhecimento sobre educação ambiental.

A gente nunca conseguiu fazer um trabalho específico de educação
ambiental ou de comunicação, né, ambiental com os pescadores [...] com
metodologia [...] era muito no improviso, né, porque a minha área de
pesquisa num é a área de educação ambiental, eu não trabalho com
educação, eu trabalho com ecologia. [...]. Essa interlocução, né, entre a
educação e o biólogo a gente sabe que precisa, mas não é a gente que faz
porque a gente não tem a conceituação teórica pra fazer isso e a gente tenta
fazer de uma forma muitas vezes, desviar do que seria o melhor, né.
(Integrante 2 da ONG - Coordenação).

Dessa forma, a ausência de um caminho metodológico claro e o não conhecimento a respeito dos princípios teóricos e metodológicos da EA, entendendo toda a sua evolução histórica a qual postula o diálogo enquanto um princípio-base do seu quefazer (FORUM GLOBAL DAS ONGs, 1992; FREIRE, 1981), constituem-se enquanto fortes obstáculos à superação de uma perspectiva tradicional e conservadora de educação ambiental, ainda tão arraigada em nossa cultura, que traz consigo a marca da antidialogicidade (SAUVE, 2005; ANDRADE E SORRENTINO, 2014a; 2014b).

Por fim, vale questionar a separação entre encontros de EA e as conversas semanais da equipe de monitoramento com os pescadores, revelando uma concepção que não compreende o processo desenvolvido, como um todo, como potencialmente educador ambientalista. Isso denota um importante desafio para a ONG de superar a lógica fragmentadora do pensamento, como sugere Bohm (2005).

\subsection{Aspectos internos}

\subsubsection{Pressupostos-base dos atores}

A partir da análise das entrevistas realizadas com os pescadores e integrantes da ONG, assim como dos documentos elaborados por esta, foi possível identificar os pressupostos-base de cada ator que permearam a relação durante o período de vigência do Projeto.

Os pressupostos-base da ONG se caracterizaram pelos princípios da conservação de espécies ameaçadas de extinção da fauna marinha brasileira, especificamente do golfinho conhecido como toninha e das tartarugas marinhas (INSTITUTO BIOPESCA, 2012). As concepções teóricas utilizadas pela organização (INSTITUTO BIOPESCA, 2012) reforçam 
esses pressupostos. Uma das referências foi a Convenção sobre a Diversidade Biológica (CDB), a qual possui como objetivo

[...] a conservação da diversidade biológica, a utilização sustentável de seus componentes e a repartição justa e equitativa dos benefícios derivados da utilização dos recursos genéticos, mediante, inclusive, o acesso adequado aos recursos genéticos e a transferência adequada de tecnologias pertinentes, levando em conta todos os direitos sobre tais recursos e tecnologias, e mediante financiamento adequado (MINISTÉRIO DO MEIO AMBIENTE, 2000, p. 9, negrito nosso).

Outra referência é o Código de Conduta para a Pesca Responsável da FAO (1995), o qual apresenta "princípios e padrões internacionais de comportamento sobre práticas [de pesca] responsáveis com o objetivo de assegurar a conservação, o manejo e desenvolvimento efetivo dos recursos aquáticos vivos, com o devido respeito ao ecossistema e a biodiversidade." (p. 1, tradução nossa ${ }^{38}$ e negrito nosso), adotando para isso a concepção de desenvolvimento sustentável apresentada pela Comissão Brundtland em 1987 (FOOD AND AGRICULTURE ORGANIZATION OF THE UNITED NATIONS, 1995; 1999). Também foi utilizado o Plano de Ação Nacional Toninha, o qual faz parte de uma série de planos de ação brasileiros com o objetivo de "[...] estabelecer estratégias de ações para a conservação das espécies ameaçadas de extinção.” (DI BENEDITTO et al., 2010, p. 12).

Além disso, é importante ressaltar que o Projeto Pescador Amigo da ONG foi submetido a um programa de patrocínio da Petrobras (Petrobras Ambiental) e, portanto, estava sujeito aos princípios presentes no regulamento do processo de seleção, o qual prioriza, como uma de suas linhas de atuação, projetos com foco na recuperação ou conservação de espécies e ambientes costeiros, marinhos e de água doce (PETROBRAS, 2012). Em relação à linha de atuação ligada à conservação estimula

[...] a execução de ações de [...] ampliação do conhecimento técnico sobre as espécies; uso não letal das espécies; atenuação e adaptação às pressões ambientais; conservação e gestão sustentável dos recursos naturais; atuação integrada de projetos de conservação da biodiversidade marinha (PETROBRAS, 2012, p. 2).

Esses pressupostos se confirmam nas falas dos integrantes da ONG: “[...] a ONG [...] tinha essa visão bem conservacionista dos mamíferos marinhos, os golfinhos e até as tartarugas também [...]” (Integrante 5 da ONG ); “[...] [a ONG] trabalhava com a toninha e a tartaruga verde, então pra ONG era isso, preservar essas espécies [...]” (Integrante 6 da ONG).

\footnotetext{
38 “....] principles and international standards of behaviour for responsible practices with a view to ensuring the effective conservation, management and development of living aquatic resources, with due respect for the ecosystem and biodiversity." (p. 1)
} 
Dessa forma, esses pressupostos-base subsidiaram os objetivos elaborados e adotados no Projeto Pescador Amigo, os quais se caracterizaram pela ampliação do conhecimento sobre as capturas acidentais de toninha e tartarugas marinhas e a capacitação dos pescadores sobre os princípios do Código de Conduta para a Pesca Responsável da FAO (INSTITUTO BIOPESCA, 2012). Nesse sentido, o Integrante 2 da ONG, ligado à coordenação do Projeto, afirmou que "[...] a ideia então era ampliar o monitoramento [...] [e] divulgar esses conceitos do código de conduta de pesca da FAO [...]" (Integrante 2 da ONG - Coordenação). E a partir disso, esperava-se dos pescadores que trouxessem os "[...] animais que morriam acidentalmente nas redes de pesca e a conscientização de não pôr uma rede em locais que poderiam capturar mais facilmente esses animais [...] que tão ameaçados de extinção, né”. (Integrante 6 da $\mathrm{ONG}$ ).

Por outro lado, os pressupostos-base dos pescadores se caracterizaram pela desconfiança sobre ONGs e outras organizações, uma vez que relatam uma relação histórica com essas marcada pela utilização dos pescadores enquanto meio para se atingir um objetivo específico, desconsiderando suas demandas e reivindicações.

[...] o grande problema desses últimos tempos, de todos esses projetos é que [...] o pescador é que é a ênfase no negócio [...] eu tenho cinquenta e um anos, há trinta e cinco anos eu vejo projeto, projeto de tartaruga, projeto de baleia, projeto de garoupa, de tudo quanto foi coisa que você possa imaginar [...] só fica bom pra você que recebe o salário [...] e o cara que vai lá no mar, que traz a tartaruga, que vem aqui, que se disponibiliza e piriri pororó, ele simplesmente [...] num é nada, ele é simplesmente um serviçal pra trabalhar pra uma ONG de graça, sendo que ele que na verdade é o pilar de toda essa estrutura pra funcionar (Pescador 17) (negrito nosso).

Nesse sentido, falam ainda da revolta por não receberem retorno dos resultados encontrados nas pesquisas que contribuíram: "por causa disso que a turma se revolta assim, muita gente [...] vem fazer pesquisa com nós [...] e não há resultado, entendeu?” (Pescador 7). Acreditam ainda que essas pesquisas contribuem para reforçar a imagem do pescador como assassino dos mares.

[...] geralmente quando se faz esse tipo de pesquisa [...] o pescador [...] é passado como assassino por ter uma proteção do golfinho, [...] da tartaruga, então qualquer pesca acidental, o que acontece com uma tartaruga, o pescador é assassino, eles acham que o pescador tem culpa (Pescador 16).

Além disso, os pescadores têm medo de sofrerem as sanções previstas na Lei de Crimes Ambientais (BRASIL, 1998), uma vez que "pro pescador trazer uma tartaruga morta é prejuízo, quem é o pescador louco que vai trazer uma tartaruga morta? Pescador nenhum vai trazer" (Pescador 16). Somam-se a isso, reforçando o pressuposto-base de desconfiança, as 
promessas recebidas e não cumpridas pelas organizações: "[Muitas organizações] vinham e prometiam, né, ‘é, nós vamos ver isso ai, pra ver se faz, se não faz, vamos falar com fulano’ e no fim sumia tudo e num acabava em nada" (Pescador 2).

Dessa forma, considerando tais pressupostos-base e o interesse da ONG considerada nesta pesquisa, de querer a colaboração dos pescadores para estudar os animais ameaçados de extinção capturados acidentalmente em suas redes de pesca (INSTITUTO BIOPESCA, 2012), ao primeiro contato dos integrantes da organização com os pescadores emergiu nestes um forte medo de serem prejudicados, como evidenciado na fala do Pescador 14: " [...] no começo até conversei com [nome integrante da ONG] que eu ia evitar trazer os bichos porque a ambiental é aqui do lado [...]". Além disso, o Pescador 6 afirma que "[...] muitos num tiveram interesse de querer participar pra poder evitar problema, talvez com medo, né, 'não, num vou lá que depois vai dá problema pra mim, tal’. Então, muitos pescadores ainda têm isso [...], de chegar e conversar com você, 'vou me prejudica' [...]” (Pescador 6).

Tal situação deflagrou um importante conflito entre os atores dessa pesquisa, o qual perdurou pelos dois anos de vigência do Projeto, fazendo emergir duas relações com características distintas entre os pescadores e a ONG: uma antidialógica e outra dialógica incipiente que serão apresentadas a seguir.

\subsubsection{Relação Antidialógica}

A relação entre a ONG e alguns pescadores foi marcada pela polarização a partir da aderência de cada ator aos seus pressupostos, de forma que não houve uma abertura à relação com o Outro, o ouvir, a empatia, a fé, a humildade e a confiança, como preconizam Bohm (2005), Isaacs $(1993 ; 1999 ; 2012)$ e Freire (1981).

O Pescador 16, aderido ao pressuposto de que trazer animais capturados acidentalmente o prejudicaria, afirmou que a ONG não falou a verdade, uma vez que

o objetivo dele [do Projeto] era pegar a causa da morte da tartaruga, só que todo mundo sabe que a tartaruga é protegida por lei [...] uma vez que o índice de tartaruga aqui no município crescesse qual era a lógica? [...] A fiscalização vai cair em cima do pescador, foi isso que nós debatemos com eles, foi isso que nós debatemos e eles falaram "não, nós queremos saber o que causa, se é por causa de comer plástico ou se ela enrosca em rede". E se esse índice dá que ela enrosca mais em rede do que comendo plástico? [...] Por que ela num chegou e falou isso "não, nós vamos fazer um índice, esse índice pode ser bom pra comprovar que ela não é morta por causa do plástico ou é morta por causa do plástico? De um lado ele pode favorecer vocês, do outro lado não". É isso que falta. 
O Pescador 11, por sua vez, apresentou a aderência a um pressuposto forte contra o patrocinador da $\mathrm{ONG}$, trazendo uma crítica muito séria sobre o fato de ele ser um grande poluidor.

[O Projeto] Só trouxe informação direto pra Petrobras que anda destruindo tudo e vem pôr a culpa no pescador. [...], sendo que o mar primeiro é do pescador, não da Petrobras. [...] por que que eles num cuidam do lixo deles? Por que que vem multa nós? Se cair uma sacolinha plástica no rio por que que o pescador que tem que pagar, sendo que nós é o que mais preservamos a praia e os primeiros a chegar na praia?

E quando questionado se os membros da ONG tentaram entender seu ponto de vista, afirmou: “não, não. Eles só queriam saber de golfinho, baleia, pinguim e tartaruga. [...] E se [...] tem alguma coisa de problema [põe a culpa no] pescador" (Pescador 11). Nesse sentido, o Pescador 17 afirmou que a relação com a ONG não chegou ao ponto de um entender o modo de pensar do outro. Disse:

nem chegou a esse ponto [...] Eles num deram uma abertura pra gente participar dessa forma, eles [...] vinham aqui "ah, a tartaruga tá morta?", "tá", "ah, é?", "Nós vamos levar pra lá pra estudar". [...] vinha carro a semana toda aí, aí parava aqui. Aí chegou uma hora sabe o que aconteceu? "ah, esses caras tão enchendo o saco"

Tais afirmações indicam que não houve o aprofundamento do conflito por parte da ONG junto a esses pescadores, reconhecendo durante as conversas que a ampliação do conhecimento das capturas acidentais fez emergir nos mesmos o medo de serem prejudicados por conta da legislação brasileira de crimes ambientais. O não enfrentamento de tal conflito, talvez numa tentativa de apaziguá-lo por parte da ONG, foi interpretada pelo pescador 16 como uma manipulação e pelos demais como uma não abertura às suas preocupações, o que os fechou para a relação.

Frente a essa resistência adotada pelos pescadores, a ONG adotou uma estratégia de persuasão dos mesmos. “[...] muitas vezes a gente tentava persuadir o pescador [risos], assim na maioria das vezes e tinha caso que não adiantava em nada, né, mas geralmente a gente tentava, mesmo eles se negando, a gente tentava uma aproximação com persuasão mesmo" (Integrante 5 da ONG). O Integrante 6 da ONG reforça: "eu acho que teve situações que os pescadores deixaram bem claro que não queriam esse tipo de informação ou até as vezes a gente naquela localidade, mas a gente insistia visitando e tal. Algumas vezes deram certo, mas a maioria eu acho que não" (Integrante 6 da ONG).

Essa postura da ONG só reforçou a antidialogicidade da relação, deflagrando momentos de violência verbal entre os atores: “[...] a gente tomava patada em campo e tinha 
que ficar quieto, né [...] já teve situações de a gente ser mandado embora do lugar [...]" (Integrante 6 da ONG). Nesse sentido, o Integrante 6 da ONG conta como era a forma de agir nessas situações:

[...] a gente falava "tudo bem, a gente entende, a gente só tá aqui falando", tentava contornar a situação, né, mas se num desse "vamos pra outra comunidade pesqueira ou vamos pra um outro pescador", as vezes na mesma comunidade pescadores aceitavam e outros não, né, então a gente entendia da melhor forma possível, tentava contornar, não deu, então vamos monitorar outro, esse num é o nosso foco do projeto, né, esse pescador num vai mudar a postura dele pelo que a gente vai falar (Integrante 6 da ONG) (negrito nosso).

Dessa forma, é possível perceber a aderência, por parte dos dois atores, aos seus pressupostos-base, o que implicou na não abertura ao Outro, criando uma polarização que não foi superada ao longo dos dois anos. Tal postura não permitiu a emergência dos aspectos internos do campo relacional dialógico, como o respeito, o ouvir genuinamente, a empatia, a fé no outro e a confiança (BOHM, 2005; ISAACS, 1999; FREIRE, 1981; 1983).

Além disso, a estratégia de persuasão adotada pela ONG para se aproximar dos pescadores pode ter reforçado a polarização entre os atores, uma vez que pode ser interpretada enquanto uma tentativa de dominar o outro, ou seja, de invasão cultural como sugere Freire (1981; 1983). Por mais genuíno que possa parecer o desejo verdadeiro da ONG de trazer os pescadores para a luta da conservação marinha, ela não parece ter reconhecido a forte marca da ocidentalidade que hospeda em si, como sugerem Andrade e Sorrentino (2014a), a qual se fez presente na relação com os pescadores. O resultado parece ter sido o oposto do desejado, ao invés da aproximação ocorreu o distanciamento, uma vez que a marca opressora ocidental pode ter reforçado os pressupostos negativos dos pescadores sobre ONGs.

Soma-se a isso, a postura de afastamento frente ao indício de fracasso da tentativa persuasiva, ou seja, não havia o enfrentamento do conflito, como sugere Bohm (2005) e Isaacs (1999), superando os estágios iniciais do diálogo, marcados pelos sentimentos de medo e de raiva. Esse distanciamento, que numa leitura ingênua pode ser confundido com respeito (BOHM, 2005), também reforça os pressupostos negativos dos pescadores, dificultando inclusive a aproximação com outras organizações. Ou seja, a ONG pode ter acabado por reforçar o desafio que ela própria encontrou ao chegar em algumas comunidades por conta de atitudes semelhantes de organizações que a antecederam.

Por outro lado, foi possível identificar algumas potencialidades para a emergência do diálogo a partir das falas dos dois atores. A primeira delas é o fato de um reconhecer o 
pressuposto-base do outro, o que se constitui enquanto um primeiro passo importante para o diálogo, como sugere Bohm (2005). Os pescadores identificaram o pressuposto-base conservacionista/preservacionista da ONG como é possível constatar nas falas apresentadas acima. Os integrantes da ONG, por sua vez, reconheceram:

[...] acho que o fato de ter vários projetos que vão nessas comunidades com esses mesmos fins que a gente foi e o que vários falaram também que "pô, vocês vêm ficam dois anos e acaba, que que vocês trazem pra gente? [...] vocês levam informação que vocês precisam e depois vocês acabam e acabou o projeto". Então tinha alguns que já tinham vivenciado outras experiências em outros projetos e aí não acreditavam mesmo nas finalidades do projeto nosso (Integrante 6 da ONG).

Além do reconhecimento do aspecto histórico referente à descrença em ONGs, também reconheceram o medo e o estereótipo negativo em torno dos pescadores: “[...] eles tem muita coisa a falar, tem muito pra mudar, mas infelizmente eles estão realmente cansados, né, de serem sempre os crápulas da situação e aí realmente falta participação, né” (Integrante 5 da ONG) (negrito nosso); “são pessoas [...] muito retraídas, elas já tem um medo de qualquer pessoa que se aproxime, então acho que quando você vai trabalhar com pescador você tem que ter consciência disso" (Integrante 4 da ONG) (negrito nosso).

Outra potencialidade são as reflexões autocríticas feitas pelo integrante da coordenação da ONG ao refletir sobre o trabalho realizado, durante a entrevista, reconhecendo as limitações do mesmo devido à falta de conhecimento sobre processos de educação ambiental, como já citado nas "Considerações sobre os aspectos externos", e à inexperiência.

[...] eu acho que [...] da equipe faltou experiência muitas vezes. Eu acho que faltou experiência, [...] trabalhar com o público, seja ele qual for, é uma das tarefas mais difíceis, né. [...] não é todo mundo que tem esse dom pra falar e se explicar, né, e faltou talvez um pouco mais de maturidade da gente sobre o que que a gente tava fazendo ali e como a gente queria. Foi tudo meio na base da experimentação, né, a gente num sabia o que ia acontecer. (Integrante 2 da $\mathrm{ONG}$ - Coordenação).

É interessante notar a partir dessa fala o reconhecimento da dificuldade de enunciar aquilo que há dentro de nós. Daí a importância do exercício de autorreflexão a partir do contato com o outro, o qual nos permite reconhecer nossos pressupostos, compartilhá-los e suspendê-los (BOHM, 2005; ISAACS, 1999). Por fim, há o indício de fé na fala do Pescador 11 em relação às ONGs, desde que atuem também em prol de suas demandas.

[...] a ONG tem que vim aqui contratar um pescador, é, informar ele melhor sobre a preservação e como se preservar, né, pra ele poder ajudar o meio ambiente. [...] ele tem que tá junto com a ONG ajudando, né, ele tem que tá 
ali ajudando, não ficar ali desconfiado com esses caras todo que andam ai na praia, sabe? Pô vem uma ONG aqui, outra de lá, mas só vem a favor da Petrobras. Aí pra nós num serve, tem que ser uma coisa que seja a favor nossa [...] se o pescador tá acreditando na ONG, tá envolvido, tá protegendo o pescador, o material do pescador, né, o pescador vai cair pra cima ajudando vocês, entendeu? Pô meu, os caras tão ajudando a gente, os caras tão preservando a gente, nossa cultura, entendeu? Nosso espaço, né. Só assim mesmo, aí dá certo. Pelo contrário sem chance. (Pescador 11).

Portanto, caso a ONG esteja aberta para uma conversa com princípios dialógicos, ou seja, ouvindo com respeito e humildade a visão do pescador, tentando entender seus pressupostos sem impor suas visões, é possível que com o tempo tanto o pescador quanto integrantes da ONG realizem juntos o exercício da suspensão (BOHM, 2005) e, portanto, a relação dialógica se fará cada vez mais presente. Inclusive, permitindo a realização de um trabalho colaborativo, unido, organizado e que acolha as diferenças como propõe Freire (1981).

\subsubsection{Relação Dialógica Incipiente}

A outra forma de relação estabelecida entre integrantes da ONG e alguns pescadores, diferentes dos citados anteriormente e que mantiveram uma postura de abertura ao Outro, apresentou alguns indícios dialógicos. Os pescadores que vivenciaram essa relação apresentaram em suas falas indícios de que desde o princípio houve o respeito, a não imposição de ideias e a humildade entre os atores. O Pescador 9 relatou que "dava pra falar de igual pra igual [...] porque num tinha muitos termos técnicos deles (da ONG)". Além disso, afirmou que "eles não vinham com a ideia concretizada pra nós e nós tinha que, vamos dizer assim, aceitar aquilo [...]" (Pescador 9).

O Pescador 4 disse que "ah, eu nunca senti nada de opressão, né, de nada assim, de julgar, nada [...] sem medo de ter uma cobrança, de uma culpa, né”. O Pescador 14, por sua vez, colocou que "quando eles [pessoal da ONG] vinham [...] eles ouviam muito, ouviam até o que num tinha a ver com o serviço deles. Coisa que a gente tava tendo dificuldade, esse negócio de documentação ambiental, conversava com eles, eles [...] viam o que podiam fazer."

Conforme essa relação foi amadurecendo alguns pescadores puderam suspender e transformar os pressupostos negativos sobre ONGs, assumindo uma postura dialógica e possibilitando um trabalho conjunto. $\mathrm{O}$ depoimento do Pescador 6 exemplifica esse processo. 
pra gente, o pouco que a gente conhecia passou pra vocês, então a gente se tornamos uma família, um procurando sempre ajudar o outro.

Quando questionado sobre como era essa relação de família o Pescador 6 afirmou: "ah, o dia-a-dia, a conquista de cada um, por intermédio da parte de vocês e da parte da gente, foi pegando confiança, um pegando confiança pelo outro e foi indo, a gente acabou se soltando" (negrito nosso). E essa confiança foi construída a partir da troca de saberes: “[...] trazer um conhecimento que a gente não tinha, foi o que tornou esse laço de confiança, que a gente passou a ter confiança [incompreensível], entendeu?” (Pescador 6).

É interessante notar que o pescador identifica a troca de conhecimento como o meio pelo qual se estabeleceu a confiança e que, portanto, permitiu a suspensão de seus pressupostos negativos em relação à ONG. No entanto, pode não ser a simples troca que permitiu a emergência desse aspecto dialógico, mas sim a forma pela qual ocorreu. Ou seja, uma troca baseada nas características citadas nas falas de seus colegas acima que indicam a humildade, o respeito e a não imposição de ideias durante os encontros com os integrantes da ONG.

O integrante 4 da ONG reforça essa ideia de uma relação de família: "teve muitos [pescadores] que eu me senti como se eu fosse parte da família, então eu chegava, brincava com a criança, abria a geladeira do cara, falava com a mulher ou com a vizinha pra depois perguntar “pô, e aí como foi a pesca? O que você capturou?" (Integrante 4 da ONG).

Outro caso interessante que indica a ocorrência de elementos dialógicos na relação é o do Pescador 14. Pouco antes de a ONG estabelecer o primeiro contato ele havia sido multado porque sua "[...] rede encostou na praia com tartaruga morta". Por isso, ele afirmou que "[...] no começo até conversei com [nome integrante da ONG] que eu ia evitar trazer os bichos porque a ambiental é aqui do lado [...]. Ela até me levou lá, conversou com eles, aí a gente começou a trazer as coisas".

Esse depoimento evidencia um momento dialógico vivido pelos dois atores em determinado momento da relação. De um lado o membro da ONG ouviu e reconheceu o medo (pressuposto) do pescador 14, propondo uma conversa com a fiscalização ambiental para tratar do conflito. De outro, o pescador estava aberto para tal conversa, realizando a suspensão do pressuposto em questão e transformando seu modo de pensar e agir, de forma que passou a contribuir com a ONG trazendo animais capturados acidentalmente. Portanto, é possível afirmar que nesse caso a suspensão dos pressupostos por parte do pescador ocorreu a partir de 
uma ação conjunta entre ele e o membro da ONG, o que demandou dos dois atores uma postura de humildade e fé, como sugere Freire (1981).

A partir da superação dos pressupostos negativos em relação à ONG foi possível a suspensão dos pressupostos ligados à prática da pesca. O Pescador 5 afirmou que a partir das conversas com o pessoal do Projeto

[...] saía com outro jeito de pensar [...]. [diferente do modo] Que [...] nós aprendemos quando era mais novo [...] [quando] eu comecei era muito peixe, pô. Você enterrava peixe na praia que você não conseguia vender tudo e hoje não, hoje, o que você jogou fora, hoje, você sente falta. Por quê? Porque num soube cuidar quando tinha muito, desperdiçou, agora num tem nada.

Nesse sentido, o Pescador 4 contou ter alterado sua prática de pesca a partir da relação com a ONG, uma vez que "[...] boieira" eu nem tenho mais [...] eu andei quebrando as boias pra botar elas de fundo, com isso diminuiu até o índice de tartaruga, né, no verão”. Além disso, conta que começou a trazer todos os resíduos encontrados na rede de pesca, a partir da relação com a ONG: “[...] o lixo que vem lá na rede, os plásticos, falo pra não jogar [...] de novo no mar, recolhe tudo de novo dentro da lancha [...] a gente traz pra cá e recolhe, né, fica tudo na poupa da lancha e recolhe [...], jogando no lixinho, né".

Com o desenvolvimento dessa confiança, a partir da suspensão dos pressupostos, parece ter surgido um sentimento de esperança, como sugere Freire (1981), por parte dos pescadores em relação ao trabalho desenvolvido pela ONG. O Pescador 8 via uma oportunidade de desmistificar a visão de que o pescador é o grande vilão do mar, ao contrário do que os pescadores que ficaram presos na relação polarizada pensavam sobre o assunto.

Muito desse projeto de vocês ajudou nós como que provava que num era muito nós que tava matando [os golfinhos e as tartarugas], tinha sacolinha, garrafa [...] prova que num é só o pescador que mata, né, porque tudo aí é pescador que mata, entendeu? Como vocês tão aí, pega "esse aqui morreu por causa de uma sacolinha, esse aqui morreu por causa de um plástico que comeu, $[. .$.$] esse aqui morreu na rede", então vamos pôr lá que setenta,$ oitenta por cento foi pescador que matou e o resto foi, entendeu? Plástico tá matando também, entendeu? Então não fica só em nós, só acusa nós.

A construção dessa relação com indícios dialógicos se desdobrou em um trabalho conjunto entre os atores, caracterizado pelo repasse dos animais capturados acidentalmente pelos pescadores à ONG para a realização da pesquisa. O Pescador 13 afirmou que "[...] a gente tava tentando se unir pra que isso [captura de golfinhos e tartarugas] diminuísse ao máximo". Dessa forma, buscou-se a união (FREIRE, 1981) para enfrentar o problema proposto.

\footnotetext{
39 "A rede boieira [...] trabalha na superfície, normalmente sem âncora, ela vai caceando" (Pescador 4)
} 
No entanto, esse trabalho conjunto parece ter se dado com base nos pressupostos da ONG, os quais foram incorporados pelos pescadores que suspenderam os seus sobre organizações não governamentais e sobre o medo das sanções em relação à captura acidental e transporte dos golfinhos e tartarugas. Tal afirmação se sustenta pela falta de indícios de que os integrantes da ONG tenham realizado a suspensão de seu pressuposto-base durante os dois anos de Projeto, sendo possível verificar durante as entrevistas que tal exercício ocorreu apenas depois de findada a relação. O Integrante 5 da ONG afirmou

que é super importante que [a relação] não seja só uma troca de favores, tipo o projeto em si tem que ser voltado realmente pra melhoria da vida deles [dos pescadores] e não "oh, vou melhorar sua vida porque melhorando sua vida eu vou ter algo em troca", mas sim algo de vou te ajudar nisso por livre espontânea vontade, entendeu? E eu vejo que auxiliar bastante eles nisso de se colocar como sociedade civil mediante os locais que eles têm voz, que eles podem ser ouvidos [...] seria legal ter uma segunda chance, mas pra fazer bem diferente [...] tentar fazer algo [...] que não tivesse que ter um fim, talvez tivesse um fim por conta própria de ter uma resposta muito positiva e a gente não precisar mais continuar com o projeto [...] deles [pescadores] irem caminhando sozinho [...] (Integrante 5 da ONG).

O Integrante 1 da ONG reforça essa ideia reconhecendo os limites impostos pelas metas e contrapartidas prometidas ao patrocinador enquanto um obstáculo para o aprofundamento da relação, como sugerem Luca e Andrade (2013). Ele disse: "eu acho que [é] difícil criar uma relação [...] de confiança e mais próxima quando, de certa forma, [...] a contrapartida se coloca entre as duas pessoas, sabe? Com o 'tem que' fazer tal coisa ou que precisa ser feito, umas regras a serem seguidas.".

O Integrante 4 da ONG complementa tal ideia, mostrando como a aderência aos pressupostos e às metas impediram o aprofundamento das contradições vividas pelos pescadores:

tivemos grandes relatos de captura, mas em compensação na parte de como trabalhar com o social ficou devendo, pecamos nisso [...] eu acredito que não era um dos pilares do projeto, aparentemente eu acredito que tenha sido isso, [...] nós estávamos lá no dia a dia com eles, poderíamos ter pensado um pouco mais nessa parte, acho que é muito carente, então acho que faltou um pouco de, foi meio que falta de experiência mesmo [...] (Integrante $4 \mathrm{da}$ ONG).

Portanto, essas visões dos integrantes da ONG mostram o reconhecimento do pressuposto conservacionista e das metas enquanto obstáculos à relação com os pescadores, fazendo emergir a vontade de superá-los em uma nova oportunidade de trabalho, indicando a realização do exercício da suspensão proposto por Bohm (2005) e Isaacs (1999). 
Dessa forma, pode-se inferir que essa relação incipiente em diálogo se deu muito mais pela abertura dos pescadores em ouvir, enunciar, respeitar e suspender (BOHM, 2005; ISAACS, 1999) do que pela postura da ONG, já que esta adotou a mesma abordagem com todos os pescadores que interagiu, deflagrando com alguns uma relação antidialógica. No entanto, não é possível afirmar com certeza quais os motivos que levaram os pescadores que apresentaram características dialógicas a adotar tal postura.

Ademais, é interessante notar que essa postura dos pescadores permitiu a emergência de atitudes dialógicas por parte da ONG, ainda que muito superficiais já que eram guiadas pelo pressuposto-base da conservação. Na situação com o Pescador 14, o integrante da ONG ouviu genuinamente o medo do pescador e agiu em busca da superação, ainda que guiado pelo seu pressuposto. E, no relato dos outros pescadores aparece o não julgamento, a não utilização de termos técnicos e a empatia, aspectos necessários para uma relação dialógica.

\subsubsection{Considerações sobre os aspectos internos}

Foi possível verificar a existência de duas formas de relação entre os atores da pesquisa. De um lado há uma relação marcada pela polarização entre a ONG e alguns pescadores, a partir do choque entre os pressupostos, a qual perdurou ao longo dos dois anos de projeto sem superar tal estágio, caracterizando-se pela antidialogicidade como sugerem Bohm (2005) e Isaacs (1999).

De outro, uma relação que apresentou alguns indícios dialógicos, de forma que parece ter havido uma abertura ao Outro e um respeito durante os primeiros contatos, o que permitiu aos atores reconhecer os pressupostos-base um do outro. A partir disso, os pescadores conseguiram realizar a suspensão de seus pressupostos em relação às ONGs, o que foi criando e fortalecendo um sentimento de confiança entre os atores. Em paralelo, certas atitudes dos integrantes da ONG, como o não julgamento, a não utilização de termos técnicos e o desejo de auxiliar os pescadores a romper com seus pressupostos ligados às organizações também fomentaram essa relação com indícios dialógicos.

No entanto, tais indícios são bastante efêmeros quando se pensa na criação de um campo relacional dialógico como proposto pelos autores teóricos dessa pesquisa. Isso porque não há indícios do exercício da suspensão dos pressupostos por parte dos integrantes da ONG durante a relação, o que indica que o diálogo incipiente identificado nesta ocorreu muito mais por uma abertura por parte dos pescadores do que da ONG. 
Além disso, essa abertura que se caracterizou por uma postura de fé e esperança no Outro (FREIRE, 1981) não apresentou indícios de que estava acompanhada do entendimento dos motivos pelos quais os pressupostos foram gerados e, portanto, pode-se inferir que o desvelamento dos aspectos histórico-culturais vividos pelos atores dessa pesquisa, principal objetivo do diálogo, não se fez presente, o que reforça a incipiência do diálogo nessa relação.

\subsection{Ação dialógica}

Foi possível encontrar indícios de que o processo reduzido proposto por Freire (1981) para se trabalhar em círculos de cultura foi iniciado. Os diagnósticos participativos realizados, por meio dos Biomapas, pela ONG junto com os pescadores foram momentos estimuladores do compartilhamento e de uma escuta genuína das contradições vividas pelos pescadores, como os conflitos vividos com os barcos de pesca industrial que adentram a área de pesca do pescador artesanal; os problemas com os órgãos de representação, sindicato e colônia de pesca; os conflitos com a fiscalização; as dúvidas sobre a legislação pesqueira (INSTITUTO BIOPESCA, 2014f). Nesse sentido, o Integrante 5 da ONG afirmou que "[O Biomapa] foi uma forma de ouvir, né, de deixar eles falarem tudo que precisava [...]”.

No entanto, tais momentos da ação dialógica não evoluíram, uma vez que "[...] ficou só na conversa assim, de fazer um dia, mas num deu tempo porque daí parou." (Pescador 5). Quando questionado se houve alguma ação planejada, executada e avaliada conjuntamente entre os atores, o Pescador 10 respondeu: "não, num teve nada assim, não me lembro de assim vamos fazer junto, nada assim. Teve ideias colocadas, mas em prática assim, pouca". Tal situação é confirmada pela fala de um integrante da ONG: "acredito que isso [ações conjuntas] tenha sido algo que ficou no papel [...] não me lembro da gente ter trabalhado sobre isso, sobre alguma coisa que eles tavam precisando, alguma reivindicação" (Integrante ONG 4). Ou seja, as contradições levantadas não foram codificadas e descodificadas, como sugere Freire (1981), para a partir do desvelamento histórico-cultural daquelas elaborar estratégias de intervenção na realidade. Dessa forma, é possível afirmar que os diagnósticos participativos se constituíram enquanto uma emergência dialógica suprimida.

Por outro lado, o integrante 5 da ONG quando questionado sobre a ocorrência de uma ação conjunta apontou: "teve, aquela reunião pro turismo em Boissucanga, foi uma organização, foi o que os pescadores pediram, vocês se mobilizaram e foi pros pescadores. Tudo bem que depois eles podem nem ter dado continuidade e nem aparecido". 
O caso de Boiçucanga/São Sebastião/SP, realmente deu um passo a mais dentro do processo de ação dialógica, uma vez que a partir do diagnóstico participativo foi solicitada nova reunião para tratar de um tema de interesse dos pescadores: o turismo de base comunitária. No entanto, no dia do novo encontro, contando com a presença de um turismólogo para uma primeira conversa sobre o assunto, a participação foi muito pequena em comparação com a primeira reunião (de 25 participantes na primeira para 9 na segunda reunião) (INSTITUTO BIOPESCA, 2014g), não sendo possível identificar ao certo qual foi o motivo de tal cenário. Após esse encontro o processo findou, não havendo novos momentos para se trabalhar o tema, o que pode indicar uma falta de priorização da continuidade dos processos educadores deflagrados.

Portanto, apesar da existência de indícios do respeito, da humildade, da fé, da esperança, da confiança e da suspensão de pressupostos, como verificado nos aspectos internos daqueles que viveram uma relação dialógica incipiente, não houve uma ação dialógica como proposta por Freire $(1981 ; 1983)$, na qual os sujeitos da relação buscaram elaborar e implementar ações conjuntas para transformar a realidade a partir do desvelamento dos aspectos histórico-culturais em que estão envolvidos, seguindo, assim, os princípios dos círculos de cultura, havendo ainda um longo caminho a percorrer para a ocorrência de um processo/relação dialógica entre os atores.

\subsection{Outros obstáculos e potencialidades dialógicas}

Foram encontrados outros obstáculos dialógicos além dos já citados anteriormente. Um deles é o não reconhecimento e deliberação pelo diálogo por parte dos dois atores, o que implica na aderência aos hábitos antidialógicos constantemente presentes em nosso cotidiano por conta do paradigma fragmentador vigente (BUBER, 1979; BOHM, 2005; ISAACS, 1999; FREIRE, 1981).

Outro obstáculo foi o tempo de contato entre os atores. A grande quantidade de localidades pesqueiras visitadas pela ONG parece ter atrapalhado o aprofundamento da relação e a realização de ações conjuntas. Quando questionado sobre o que o Projeto desenvolvido pela ONG não fez, mas poderia ter feito, o Pescador 10 afirmou: "Eu penso que mais vezes, cara, ter mais [encontros]. Eu acredito que foi pouco, foi muito lugar, mas foi pouco".

Aliado a isso está a percepção do Integrante 4 da ONG de que dois anos é um tempo pequeno para aprofundar a relação e tratar das contradições vividas pelos pescadores, o que 
reforça o desconhecimento dos preceitos dialógicos sugeridos por Bohm (2005) e Freire (1981; 1983), os quais afirmam que tal relação pode ser vivida e estimulada em tempo menor do que o citado. A Integrante afirmou: “[...] dois anos é tempo de criar informações, criar o banco de dados, agora de trabalhar mesmo, ter um engajamento com a comunidade pesqueira não, pouco tempo e não daria pra isso" (Integrante ONG 4).

Outro ponto que pode ser considerado um obstáculo é o indício de que não houve a síntese cultural nos encontros do diagnóstico e dos cursos, pois os conflitos emergentes das diferenças com os pescadores que não conseguiram suspender os pressupostos negativos eram apaziguados em nome da polidez. De acordo com o Pescador 7:

No momento da discussão [durante os encontros de educação ambiental] o pessoal brincava também pra distrai um pouquinho, entendeu? Tirar o foco da conversa [...] quando a conversa tava ficando meio agitada o pessoal já entrava brincando pra descontraí um pouquinho, entendeu? [...] ele [o pessoal do Projeto] já entrava meio que assim pra tira aquele foco daquela conversa ali e chegar num acordo, né.

Chegar num acordo e tirar o foco do conflito indicam a vontade de manter um ambiente de polidez entre os atores, o que não permite a emergência do diálogo a partir do conflito (BOHM, 2005; ISAACS, 1999). Por outro lado, esse obstáculo traz em si uma potencialidade dialógica, uma vez que o chegar a um acordo implica numa negociação, a qual para Bohm (2005) é uma etapa preliminar do diálogo.

Uma potencialidade a ser considerada é a questão dos locais de encontro. Se por um lado as praias e trapiches não correspondem às exigências postas por Isaacs (1999) para a ocorrência do diálogo, como evidenciado no subitem dos "aspectos externos", de outro ela pode indicar um cuidado por parte da ONG com os pescadores, o que pode ser um indício dialógico. As falas dos pescadores a seguir confirmam tal ideia: "[...] vocês vêm de tão longe pra tá na nossa comunidade aqui. Mostra uma importância pra gente [...]” (Pescador 13); “Então, eu acho [...] que quando vocês vem até aqui [é] legal [...] Isso é bom, cara, pra nós, entendeu? [...] mostra um esforço que já que as pessoas num quer ir até lá, eles [ONG] vem pra ouvi a comunidade pesqueira [...] entendeu?" (Pescador 7).

Outra potencialidade é a troca de conhecimento promovida entre as comunidades pesqueiras de diferentes municípios pela ONG. O Pescador 12 afirmou que

toda vez que vocês vêm pra cá vocês trazem alguma experiência de outra região pra nós. [...]. Então é um aprendizado dia a dia com vocês, que vocês sempre trazia pra gente. [...]. Porque a gente quase não sai daqui e vocês não, vocês rodam o litoral todinho, sempre tem uma ideia lá que num chegou aqui ou tem uma ideia aqui que num chegou lá. Isso é bom não só pra vocês, mas 
pro pescador do litoral norte, [...] quanto pra gente aqui. Às vezes um estilo de pescaria que tá dando certo lá, às vezes num chegou aqui ainda pra gente. Então essa troca de informação é muito bom. Tanto que tem um estilo de pescaria que eu faço hoje aqui, veio lá do litoral norte, a pescaria de caracol [...]. [O integrante da ONG] que trouxe, falou "oh, o pessoal tá fazendo assim, tá matando peixe pra caramba" [...]. Falei [...] “como é que faz?". Daí [o integrante da ONG] tirou um bocado de foto, trouxe aqui e a gente deu certo. Uma coisa que num tinha nada a ver com o projeto, mas é uma troca de ideia.

Aqui é possível perceber a atuação da ONG enquanto polinizadora de ideias entre as comunidades. Nesse sentido, a organização começou a construir pontes entre as comunidades distantes, o que é um elemento importante para fortalecer a articulação e união dos pescadores, aspectos importantes para a ação dialógica de Freire (1981).

\subsection{Considerações sobre o campo relacional estabelecido na relação entre os} atores e suas consequências

Tendo em vista o exposto acima é possível perceber a incipiência do diálogo na relação entre os atores. Os aspectos externos dialógicos analisados nas diferentes formas de contato entre os mesmos se limitaram à frequência semanal das conversas e a algumas formas de disposição dos participantes (triângulo de três pessoas, retângulo de quatro pessoas, semicírculo e círculo) nas conversas, nos diagnósticos participativos e nos cursos sobre práticas de pesca responsável.

Quanto às estratégias pedagógicas adotadas nos diferentes encontros é possível afirmar que aquela utilizada nos diagnósticos participativos foi a única que potencializa a emergência do diálogo. Por outro lado, os cursos sobre empreendedorismo sustentável, práticas de pesca responsável e o concurso de práticas e tecnologias de pesca responsável se constituíram pela adoção de estratégias pedagógicas obstaculizadoras do diálogo, como palestra, discussões e competição, respectivamente.

Sobre os aspectos internos foi possível constatar o estabelecimento de uma relação antidialógica e de outra que chamei de dialógica incipiente por apresentar alguns indícios de emergência do diálogo, não sendo, no entanto, fortes o suficiente para caracterizar a existência de um campo relacional dialógico como sugerem Bohm (2005) e Isaacs (1999).

Em relação à ação dialógica foi possível verificar o início de um processo de acordo com os princípios dos círculos de cultura. No entanto, a falta de priorização da continuidade de tal processo nos permite afirmar que não houve uma ação dialógica como proposto por Freire (1981), caracterizando-se, assim, enquanto uma emergência dialógica suprimida. É 
possível afirmar que o campo relacional estabelecido entre os atores desta pesquisa se caracterizou pela predominância de obstáculos ao diálogo com breves momentos de indícios dialógicos, o que coloca os atores bem na base da espiral dialógica.

O cenário encontrado na pesquisa de campo condiz com os resultados obtidos a partir da revisão bibliográfica sobre a trajetória histórica dos pescadores, corroborando a marca da existência antidialógica em suas vidas com a forte dominação e opressão imposta pelo modelo urbano-industrial capitalista (DIEGUES, 1983; 1995; 2001; FREIRE, 1981; 1983; MARRULFILHO, 2001) e se constituindo enquanto um forte obstáculo à relação com a ONG. Apesar disso, foi possível verificar que alguns pescadores conseguiram superar tal situação, abrindose aos integrantes da organização e iniciando uma relação com alguns indícios dialógicos.

Em relação à ONG e ao histórico das organizações desse tipo foi possível perceber um distanciamento dos princípios adotados pelos centros de educação popular (OLIVEIRA; HADDAD, 2001; STEIL; CARVALHO, 2007) e das ONGs cidadãs (GOHN, 2010; 2013; MACHADO, 2012), uma vez que não houve a promoção do desvelamento histórico-cultural, permitindo identificar as causas das contradições vividas. Esse distanciamento é reforçado pela verificação da aderência aos pressupostos da proteção da fauna marinha, desconectada dos aspectos sociais, os quais se fizeram presentes no processo educador ambientalista desenvolvido.

Uma EA pautada por esses pressupostos promove uma visão limitada da questão ambiental, reduzindo-a ao aspecto biológico com o propósito de preservar ou de proteger para explorar os recursos naturais em longo prazo, sob o discurso de um desenvolvimento sustentável (SAUVÉ, 2005), o qual estimula um modelo de desenvolvimento ocidental a ser atingido baseado na concepção de progresso linear realizado pelos países desenvolvidos e industrializados do Norte (DIEGUES, 1992), carente de uma perspectiva crítica sobre o sistema de produção e consumo urbano-industrial (DIEGUES, 2008; CARVALHO, 2004; SORRENTINO, 1995) e desconsiderando, no caso desta pesquisa, as demandas dos pescadores (DIEGUES, 1983; 2001).

Dessa forma, é possível perceber que tal concepção de EA não promove a transição para sociedades sustentáveis, muito menos para um novo modelo de pesca, já que se baseia em princípios antidialógicos, enxergando o Outro (principalmente a natureza) de maneira objetificante, reforçando, por fim, o próprio modelo de desenvolvimento que gerou todas as contradições que vivemos hoje. Por outro lado, uma perspectiva crítica (CARVALHO, 2004), a qual foi adotada pelo menos no discurso da ONG aqui pesquisada, constituindo-se enquanto 
uma potencialidade por caracterizar um reconhecimento da importância de tal concepção, permite e estimula o desvelamento dos aspectos histórico-culturais por meio do diálogo, constituindo-se enquanto um caminho potencializador da transição almejada.

Com isso, pode-se afirmar que o processo de EA desenvolvido pela ONG se caracterizou pela predominância de aspectos antidialógicos, constituindo-se, assim, enquanto um caminho com poucos elementos daqueles sugeridos por Bohm (2005) e Isaacs (1999) para os grupos de diálogo e por Freire (1981) para os círculos de cultura. Tal processo de EA promovido pela ONG reforça os aspectos históricos antidialógicos vividos pelos atores que, por sua vez, reforçam a adoção de uma concepção de EA conservadora e antidialógica. E, dessa forma, esse ciclo vicioso mantém o status quo.

Por outro lado, o distanciamento da concepção dialógica, verificado no caso investigado, não implica aqui numa denúncia culpabilizadora, uma vez que se entende que a organização atuou de tal maneira como decorrência de uma sociedade na qual os pressupostos neoliberais, produtivistas, individualistas e alienantes são predominantes (DIEGUES, 2008; GOHN, 2010; STEIL; CARVALHO, 2007), reforçando as características de uma existência antidialógica, pautada pela palavra-princípio Eu-Isso (Buber, 1979; 2014). Estamos aderidos a tal realidade, sem, muitas vezes, conseguir ter uma leitura crítica sobre ela.

A superação das fortes marcas antidialógicas que nós, educadoras(es) ambientais, recebemos e alimentamos ao longo de nossas vidas se apresenta enquanto importante desafio a ser superado para que nossa práxis (FREIRE, 1981) seja de fato transformadora. Para isso, é necessário o exercício do mergulho em si próprio (OCA, 2016) para que se possa identificar e desconstruir as marcas antidialógicas aprendidas e nutridas ao longo da vida. Esse mergulho permitirá a vivência do diálogo interno, no qual diversos conflitos emergirão, já que os pressupostos antidialógicos se chocarão com os dialógicos. Esse exercício individual, por sua vez, será potencializado a partir do encontro com o Outro, em que haja a busca coletiva por pensar e agir com base nos elementos propostos nos grupos de diálogo e nos círculos de cultura.

Esse exercício individual e coletivo, o qual pode ser deflagrado por uma EA dialógica (ANDRADE, 2013; ANDRADE; SORRENTINO, 2014a; 2014b; FORUM GLOBAL DAS ONGs, 1992; LUCA; ANDRADE, 2013; ÓRGÃO GESTOR DA PNEA, 2005; 2006; SORRENTINO et. al., 2013), realizado pelos integrantes da ONG junto com os pescadores artesanais permitirá o incremento da existência dialógica (BUBER, 2014) dos dois atores. De um lado, desconstruindo as anteriormente referenciadas marcas da ocidentalidade 
(ANDRADE; SORRENTINO, 2014a; 2014b) muitas vezes presentes nas/nos educadoras(es) ambientais de ONGs ambientalistas e agregando à proteção da fauna a dimensão sociocultural (DIEGUES, 2008; JACOBI, 2000; SAUVÉ, 2005). De outro, a desconstrução dos mitos opressores hospedados nos pescadores, rompendo com a aderência à realidade mitificada (FREIRE, 1981; 1983).

E, pensando na realização de tal exercício, vale destacar as potencialidades dialógicas encontradas nos dois atores da pesquisa. Alguns pescadores apresentaram uma forte postura de abertura ao Outro, inclusive se permitindo enfrentar e superar medos adquiridos em outras relações, realizando, assim, a suspensão de tais pressupostos. A ONG, por sua vez, apresentou importantes atitudes estimuladoras do diálogo, como a escuta genuína, o respeito, a não utilização de linguajar acadêmico e a não imposição de ideias. Todas essas potencialidades devem ser estimuladas juntamente com a criação de novas, de forma a permitir o avanço na espiral dialógica e a efetividade da transição para um novo modelo de pesca e de sociedade. 


\section{CONSIDERAÇÕES FINAIS}

Nesta pesquisa se buscou, a partir dos princípios do diálogo, analisar a relação entre integrantes de uma ONG ambientalista e pescadores artesanais marítimos, motivada pela intenção da primeira em promover a transição para um novo modelo de pesca de acordo com os princípios enunciados pelo Código de Conduta para a Pesca Responsável da FAO.

A transição para um novo modelo de pesca implica na transição para um novo modelo de relação entre os seres. Nesse sentido, buscar tal transformação demanda a superação do paradigma atual, estritamente pautado na racionalidade, no qual a relação objetificante predomina, abrindo espaço para outras formas de relação (BOHM, 2005; BUBER, 1979; 2014; FREIRE, 1981; 1983). O caminho para essa transformação, sugerido por Martin Buber, David Bohm, William Isaacs e Paulo Freire é o diálogo, no qual se busca a comunhão com o Outro, a partir do reconhecimento e aceitação das diferenças. Portanto, ele não é apenas uma modalidade de conversa, diferente da discussão e do debate (BOHM, 2005), mas sim uma forma diferente de ser e estar no mundo (BUBER, 1979; 2014; FREIRE, 1981).

Tendo isso em vista, a relação construída entre os integrantes da ONG e pescadores artesanais durante um projeto desenvolvido pela primeira, com dois anos de duração, caracterizou-se por fortes obstáculos ao diálogo, tendo alguns momentos de atitudes dialógicas, o que os coloca na base da espiral dialógica. Os resultados encontrados são condizentes com o alerta feito por Buber (1979) de que há uma predominância da relação EuIsso em nossas interações, reforçando uma existência antidialógica generalizada. Esse alerta se confirma também a partir da análise dos aspectos históricos dos dois atores. Os pescadores artesanais lutam contra a desvalorização cultural e opressão sofrida pelos valores urbanoindustriais (DIEGUES, 1983; 1995; 2001), tendo uma existência marcada pela antidialogicidade, e as ONGs passaram a sofrer forte influência dos preceitos neoliberais, a partir da década de 1990 no Brasil, havendo uma distinção entre as que adotaram tais princípios, promotores da antidialogicidade, e as que buscaram se alinhar com sua essência advinda dos centros de educação popular (GOHN, 2010; 2013; STEIL; CARVALHO, 2007).

Esta pesquisa também buscou contribuir para o aprofundamento da compreensão do diálogo e da formulação de indicadores que permitam averiguar a dialogicidade no fazer das educadoras(es) ambientais, como sugerem Andrade, Luca e Sorrentino (2012) e Luca e Andrade (2013). Para isso, foi desenvolvida uma síntese das ideias de Martin Buber, David Bohm, William Isaacs e Paulo Freire sobre o diálogo, em que se parte da ideia de uma espiral 
dialógica composta por diferentes caminhos que a incrementam, sendo os grupos de diálogo e os círculos de cultura dois deles. A partir disso, sugeriu-se a união dos elementos presentes nesses dois caminhos metodológicos (BOHM, 2005; ISAACS, 1999; FREIRE, 1981) com a criação de três categorias de análise sobre o diálogo: aspectos externos, aspectos internos e ação dialógica, cada uma compostas por perguntas-indicadoras.

Em relação aos aspectos externos do diálogo estão: a frequência dos encontros; o número de pessoas envolvidas nos mesmos; a disposição em que se encontram; a acústica do local escolhido. Quanto aos aspectos internos do diálogo estão: a deliberação por este; a possibilidade de todos se expressarem, respeitando e ouvindo, por sua vez, os outros; a emergência de conflitos; a exposição e suspensão dos pressupostos, ou ao menos o reconhecimento dos pressupostos alheios; o desvelamento de aspectos culturais; a presença do amor, da humildade, da fé, da confiança, da esperança e do pensar crítico. No que se refere à ação dialógica estão: o envolvimento da comunidade no processo de investigação temática; a realização do exercício de codificação e descodificação, no qual se permite "re-admirar" as admirações anteriores; a realização de círculos de investigação temática e, posteriormente, de círculos de cultura; as tomadas de decisão conjuntas entre os atores do processo de educação ambiental que se desdobraram em um trabalho colaborativo, organizado e que acolhe as diferenças, a partir do desvelamento da realidade por meio dos temas geradores.

Ademais, a pesquisa corroborou os obstáculos apresentados por Andrade e Sorrentino (2014a) entre educadoras(es) ambientais e comunidades tradicionais, reforçando assim a importância do diálogo enquanto um princípio-base a ser adotado nos processos de EA para que sejam de fato transformadores (SORRENTINO et. al., 2013). Portanto, o diálogo se constitui enquanto um grande desafio a ser mais bem estudado e aprofundado nos processos de EA, analisando principalmente sua presença ou ausência na práxis das educadoras(es) (FREIRE, 1981).

Nesse sentido, algumas recomendações podem ser feitas à $\mathrm{ONG}$ enquanto propositora do processo educador desenvolvido com os pescadores, para que se constitua enquanto uma liderança dialógica (ISAACS, 1999; FREIRE, 1981).

Uma primeira recomendação é que a transição para um novo modelo de pesca não pode se limitar apenas à transformação das técnicas pesqueiras utilizadas e à promoção de novas tecnologias, como foi feito. É preciso buscar transformar-se em comunhão com o Outro (BUBER, 1979; 2014; FREIRE, 1981; 1983), rompendo com a lógica fragmentadora do conhecimento (BOHM, 2005). Isso demanda o próprio reconhecimento do diálogo enquanto 
um caminho possível para tal transição, entendendo a proposta de Bohm e Isaacs sobre os grupos de diálogo, de Freire sobre os círculos de cultura e demais caminhos dialógicos sugeridos por outros autores não considerados nesta pesquisa.

Outro ponto é a abertura para a realização do exercício de suspensão dos pressupostos, não se prendendo às ideias conservacionistas. A vontade genuína de mudar a pesca em busca de um ambiente mais saudável, se feita de maneira antiadialógica, pode ter o efeito contrário do desejado, afastando as pessoas da causa ambientalista e da transição almejada.

O aprofundamento dos princípios teóricos e metodológicos da EA se faz importante para entender a relevância de se realizar um processo continuado, articulado, permanente e com a totalidade (BRASIL, 1999; ÓRGÃO GESTOR DA PNEA, 2014; SORRENTINO, 2005). Nesse sentido, outra questão pertinente é lidar com as metas quantitativas prometidas e esperadas pelo patrocinador, as quais obstaculizam a realização de uma EA dialógica, uma vez que impedem o aprofundamento da relação, o caráter contínuo, permanente e articulado do processo.

Aprimorar os aspectos externos dos encontros para que se crie um ambiente fértil para o diálogo. Propiciar encontros em círculo, nos quais todos tenham poder de fala, com uma pauta que tenha espaço para se falar das demandas dos pescadores e com uma frequência maior com o objetivo de desvelar os aspectos histórico-culturais em que se vive.

Enfrentar os conflitos enquanto oportunidades para o aprofundamento da relação com o Outro, não assumindo a postura da persuasão. Aqui, em específico, é importante conversar sinceramente a respeito das implicações da captura acidental para os pescadores.

Reconhecer e reforçar os indícios dialógicos identificados na relação dialógica incipiente, como a escuta genuína, o respeito, a não imposição de ideias e o reconhecimento do Outro. Além disso, dar continuidade ao trabalho iniciado com os diagnósticos participativos, aprofundando o conhecimento de pedagogias dialógicas.

Dessa forma, ressalta-se a importância de se realizar mais pesquisas com organizações ambientalistas, uma vez que os resultados encontrados aqui parecem não ser uma particularidade do caso estudado, mas algo generalizado nas relações entre integrantes das ONGs e os sujeitos com os quais trabalham, como se pôde verificar a partir dos pressupostos negativos dos pescadores entrevistados nessa pesquisa sobre ONGs construídos ao longo de suas trajetórias de vida. 
Assim, a realização de pesquisas para averiguar a existência ou não do diálogo nos processos educadores promovidos por ONGs ambientalistas e de investigações que aprofundem o conhecimento sobre a força histórica dos pressupostos preservacionistas/conservacionistas nessas organizações, assim como a força histórica dos pressupostos negativos dos pescadores sobre entidades ambientalistas podem ser de grande valia.

Além disso, investigar outros caminhos dialógicos, sugeridos por autores não considerados nessa pesquisa, com o intuito de incrementar a espiral dialógica é de grande relevância, permitindo o aperfeiçoamento dos indicadores do diálogo. Sugere-se também a realização de pesquisas que investiguem a relação do diálogo com o incremento da potência de agir em prol da transição para sociedades sustentáveis em processos de EA.

Espera-se que esta pesquisa possa servir a todas as educadoras(es) ambientais que atuam nos mais diversos contextos, especialmente em organizações ambientalistas, estimulando a reflexão em torno de suas concepções e práticas adotadas nos processos de educação ambiental que desenvolvem, assim como o tipo de relação que estabelecem com os sujeitos que participam dos mesmos.

Por fim, apresenta-se aqui uma complementação da síntese teórica sobre o diálogo como uma possível contribuição do presente trabalho a ser utilizada por futuras pesquisas sobre o tema. Uma sugestão de processo metodológico caracterizado pela união dos procedimentos de codificação e descodificação, propostos por Freire $(1981$; 1983) e de suspensão dos pressupostos, indicado por Bohm (2005) e Isaacs (1999) que potencialize a caminhada em direção à existência dialógica buberiana.

A síntese proposta aqui tem na codificação o primeiro momento do processo, uma vez que ela permite a representação de uma situação existencial vivida na realidade concreta. A partir disso, pode-se partir tanto para a descodificação, quanto para a suspensão. Realizando o exercício de comparação entre esses dois procedimentos foi possível perceber que ambos são parecidos. A descodificação é composta pelos quatro momentos sugeridos por Freire (1983): observação da codificação; descrição da mesma; "re-admiração" das admirações anteriores; análise crítica. A suspensão dos pressupostos, por sua vez, pode ser entendida por três momentos a partir do que apresentam Bohm (2005) e Isaacs (1999): a escuta genuína, que pode ser compreendida enquanto um paralelo à observação sugerida por Freire; a disponibilização para si e para os outros sobre o que se pensa a respeito da codificação em questão, constituindo-se enquanto um paralelo a descrição de Freire; o entendimento do 
processo pelo qual tal forma de pensar se constituiu, observando as sensações corporais e emoções que surgem quando nos deparamos com pressupostos similares ou antagônicos aos nossos, o que nos parece se aproximar do exercício de "re-admirar" as admirações anteriores e do aprofundamento da análise crítica, inclusive oferecendo a esta mais elementos, a partir da observação das sensações e emoções, para efetivamente ser crítica.

Dessa forma, o procedimento metodológico que se propõe aqui é composto por quatro momentos: (1) codificação; (2) observação da codificação ou escuta genuína; (3) descrição da codificação; (4) "re-admiração" das admirações, observando as sensações corporais e emoções e analisando criticamente todo o processo. Esses momentos compõem um ciclo virtuoso (Figura 4) que permite a emergência da criticidade e conscientização (freireana) e do pensamento coletivo e coerente (bohmiano), podendo culminar no incremento de uma existência dialógica (buberiana).

Figura 4 - Os quatro momentos do procedimento metodológico
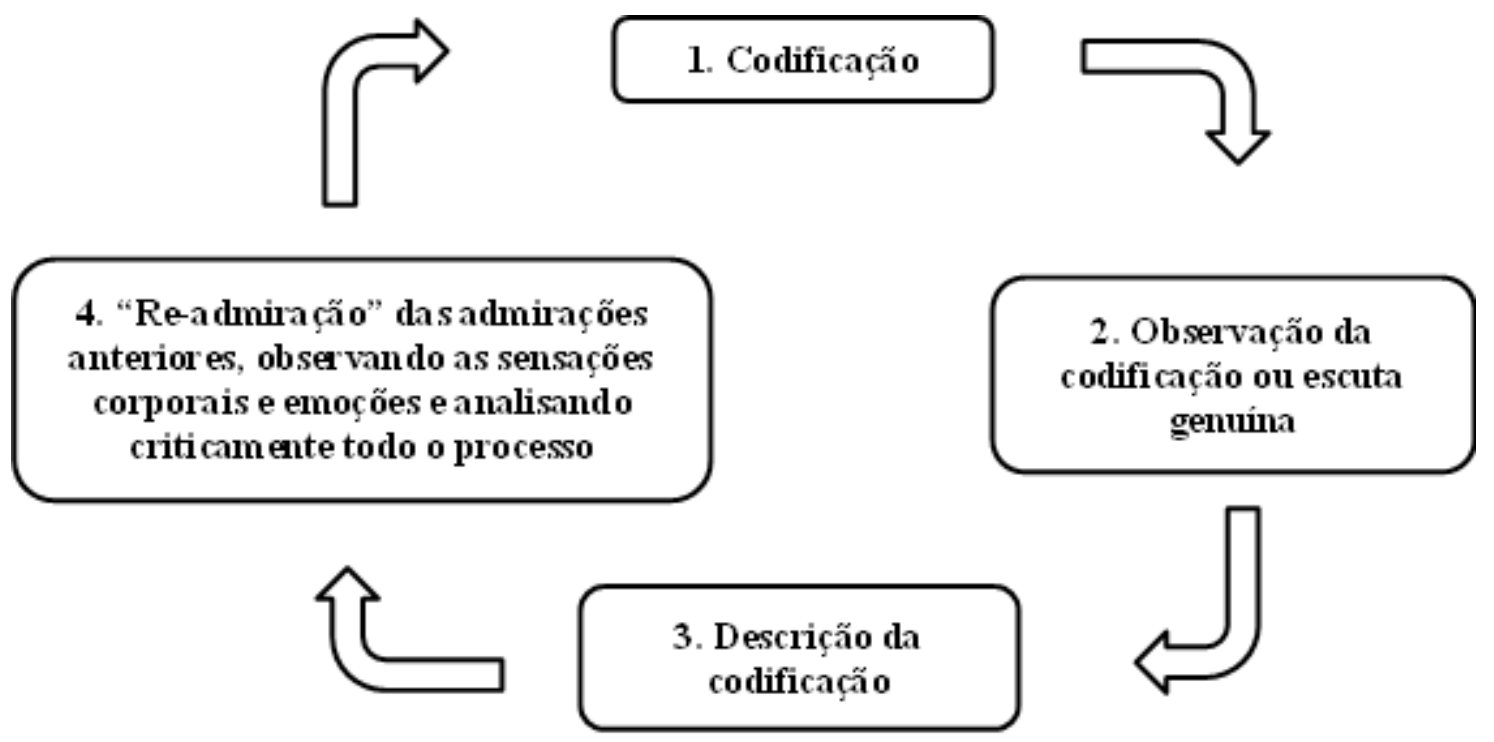

Fonte: própria.

Por exemplo, no diálogo entre uma ONG, ou qualquer outra agência que objetive promover transformações por meio de processos educadores, em uma determinada realidade, e um coletivo de pescadores, ou qualquer outro coletivo de agentes de transformação de uma determinada realidade, o primeiro momento é o da codificação da realidade, a qual deverá apresentar as situações vividas pelos sujeitos que participam do diálogo e suas possíveis contradições.

Essa codificação pode ser feita previamente ao encontro, realizando um levantamento das situações vividas e suas possíveis contradições, sendo apresentada por meio de uma 
fotografia, um vídeo ou uma poesia, por exemplo. Ou pode ser feita durante o encontro a partir de testemunhos de um ou vários participantes, a partir dos quais vão emergindo as contradições.

À medida que a codificação é exposta, faz-se necessário observá-la e/ou escutá-la, a depender do instrumento utilizado, de forma genuína, exercitando a presença e atenção no encontro, caracterizando o segundo momento. De posse dessa presença em que se identifica a realidade codificada, começa-se o terceiro momento, a descrição. Cada participante terá a possibilidade de disponibilizar para si e para os outros o que pensa sobre o que se apresenta codificado e por existir diferentes trajetórias de vida, emergirão leituras da realidade baseada em diferentes pressupostos.

É a partir do enfrentamento dos conflitos entre pressupostos e do contato e da abertura ao diferente que se abrirá a oportunidade de "re-admirar" as admirações anteriores, observando as sensações corporais e emoções e analisando criticamente todo o processo, constituindo o quarto momento. Aqui se busca rever as formas de pensar e agir, a partir de diversos questionamentos: por que penso da forma que penso sobre esse assunto? De onde veio essa forma de ver tal aspecto da vida? Com quem e em que contexto adquiri essa visão? Desde quando penso dessa forma? O que sinto (sensações corporais e emoções) quando escuto a defesa de algo que abomino? Por que abomino esse algo? Será que realmente é abominável? O que sinto (sensações corporais e emoções) quando escuto algo que acredito e concordo? Será que esse algo é realmente verdadeiro? Etc.

Esse processo de autorreflexão, oportunizado pelo encontro de diferentes formas de viver a vida se apresenta enquanto uma oportunidade de se criar um pensamento crítico, coerente e coletivo, no qual a união, a solidariedade, o cuidado com o Outro, o sentimento de pertença e responsabilidade emergem, permitindo a ação conjunta em prol da transformação das contradições histórico-culturais vividas. 


\section{REFERÊNCIAS BIBLIOGRÁFICAS ${ }^{40}$}

ABONG. Sstatuto Social. $2016 . \quad$ Disponível em: <http://www.abong.org.br/quem_somos.php?id=3> Acesso em: 10 fev. 2018.

ANDRADE, D. F.; LUCA, A. Q.; SORRENTINO, M. O diálogo em processos de políticas públicas de educação ambiental no Brasil. Educ. Soc., Campinas, v. 33, n. 119, p. 613-630, abr.-jun. 2012. Disponível em: <http://www.cedes.unicamp.br> Acesso em: 15 fev. 2017.

ANDRADE, D. F. O lugar do diálogo nas políticas públicas de educação ambiental. Tese (Doutorado em Ciência Ambiental) - Universidade de São Paulo, 2013.

ANDRADE, D. F.; SORRENTINO, M. Dialogue as a Basis for the Design of Environmental Pedagogies. Journal of Education for Sustainable Development. v. 8 n. 2, p. 143-154, 2014b.

ANDRADE, D. F.; SORRENTINO, M. Estamos prontos para ouvir "não" e respeitá-lo? As limitações nas relações de participação entre o ocidente e outras culturas. In: VI Conferência Internacional de Educação Ambiental e Sustentabilidade "O melhor de ambos os mundos". Bertioga-SP, 2014. Anais eletrônicos... São Paulo: Sesc São Paulo, 2014a. Disponível em: < https://www.researchgate.net/publication/270450310_estamos_prontos_para_ouvir_nao_e_re speita-lo_as_limitacoes_nas_relacoes_de_participacao_entre_o_ocidente_e_outras_culturas> Acesso em: 14 jun. 2017.

ANDREOLI, V. M.; ANACLETO, A. Compartilhando saberes: os conhecimentos tradicionais e a educação ambiental. In: IX EPEA - Encontro Paranaense de Educação Ambiental. Guarapuava-PR, 2006. Anais eletrônicos... Guarapuava-PR, 2006. Disponível em: < www.isepeguaratuba.com.br/inc/pdf/isepe_guaratuba_artigo007.pdf> Acesso em: 10 fev. 2015.

ANDREOLI, V. M. Diálogos entre os conhecimentos tradicionais e as práticas conservacionistas da natureza: uma possível abordagem. In: I Seminário Nacional Sociologia \& Política, Paraná, 2009. Anais eletrônicos... Paraná: UFPR, 2009. Disponível em: <www.humanas.ufpr.br/site/evento/SociologiaPolitica/GTs-

ONLINE/GT7\%2520online/dialogos-entre-

conhecimentosVanessaAndreoli.pdf $+\& \mathrm{~cd}=1 \& \mathrm{hl}=\mathrm{pt}-\mathrm{BR} \& \mathrm{ct}=\mathrm{clnk} \& \mathrm{gl}=\mathrm{br}>$ Acesso em: $10 \mathrm{fev}$. 2015 .

ARAGÃO, A. L. A.; NAVARRO, A. Diálogos em Diálogo: David Bohm, Paulo Freire e Mikhail Bakhtin. Educação em Questão, v. 19, n. 5, 2004.

\footnotetext{
${ }^{40}$ De acordo com a Associação Brasileira de Normas Técnicas (ABNT NBR 6023)
} 
ARAUJO, I. A. A educação ambiental não formal no contexto das organizações não governamentais ambientalistas do litoral norte do Estado de São Paulo. Dissertação (Mestrado em Educação), UNIMEP, Piracicaba, 2006.

AVANZI, M. R. Tecido a muitas mãos: experienciando diálogos na pesquisa em educação ambiental. Tese (Doutorado em Educação) - Universidade de São Paulo, 2005.

BARDIN, L. Análise de conteúdo. Lisboa: Edições 70, 1979.

BECKER, H. S. Métodos de pesquisa em ciências sociais. $2^{a}$ ed. São Paulo: HUCITEC, 1994.

BEZERRA, D. O. S. Educação ambiental não-formal: a práxis coletiva dos pescadores artesanais no rio Paraguai, Cáceres/Mato Grosso/Brasil. Tese (Doutorado em Ecologia e Recursos Naturais) - Universidade Federal de São Carlos, 2009.

BOHM, D. A totalidade e a ordem implicada. São Paulo: Cultrix, 1980.

BOHM, D. Diálogo: comunicação e redes de convivência. São Paulo: Palas Athena, 2005.

BONI, V.; QUARESMA, S. J. Aprendendo a entrevistar: como fazer entrevistas em Ciências Sociais. Revista Eletrônica dos Pós-Graduandos em Sociologia Política da UFSC, v. 2, n. 1, $2005 . \quad$ Disponível em: <https://periodicos.ufsc.br/index.php/emtese/article/viewFile/18027/16976+\&cd=1\&hl=ptBR\&ct=clnk\&gl=br> Acesso em: 15 jun. 2015.

BORELLI, E. Neoliberalismo e as ONGs na América Latina. AURORA, v. 2, n. 2, 2008.

BRASIL. Decreto ${ }^{\circ}$ 9.004, de 13 de março de 2017. Transfere a Secretaria de Aquicultura e Pesca do Ministério da Agricultura, Pecuária e Abastecimento e a Secretaria Especial da Micro e Pequena Empresa da Secretaria de Governo da Presidência da República para o Ministério da Indústria, Comércio Exterior e Serviços, e dá outras providências. Diário Oficial da União, Brasília, DF, 14 mar. 2017, Seção 1, p 19.

BRASIL. Lei 9.605, de 12 de fevereiro de 1998. Dispõe sobre as sanções penais e administrativas derivadas de condutas e atividades lesivas ao meio ambiente, e dá outras providências. Diário Oficial da União, Brasília, DF, 13 fev. 1998, seção 1, pág. 1. 
BRASIL. Lei $\mathrm{n}^{\circ}$ 12.612, de 13 de abril de 2012. Declara o educador Paulo Freire Patrono da Educação Brasileira. Diário Oficial da União, Brasília, DF, 16 abr. 2012, n. 73, seção 1, p.1.

BRASIL. Lei 13.266, de 5 de abril de 2016. Extingue e transforma cargos públicos; altera a Lei $\mathrm{n}^{\circ} 10.683$, de 28 de maio de 2003, que dispõe sobre a organização da Presidência da República e dos Ministérios, e a Lei $\mathrm{n}^{\circ}$ 11.457, de 16 de março de 2007; e revoga dispositivos da Lei $\mathrm{n}^{\circ}$ 10.683, de 28 de maio de 2003. Diário Oficial da União, Brasília, DF, 6 abr. 2016, seção 1, p. 1.

BRASIL. Lei 9.795, de 27.04.1999. Dispõe sobre Educação Ambiental e institui a Política Nacional de Educação Ambiental, e dá outras providências. Diário Oficial da União, Brasília, DF, 28 abr. 1999, seção 1, p. 1.

BRAVO, M. D. NA MARÉ DAS LEMBRANÇAS: memória, pesca artesanal, globalização e educação ambiental no contexto da Laguna dos Patos. Dissertação (Mestrado em Educação Ambiental) - Universidade Federal do Rio Grande, 2011.

BUBER, M. Eu e Tu. $2^{\text {a }}$ ed. São Paulo: Cortez \& Moraes, 1979.

BUBER, M. Do diálogo e do dialógico. São Paulo: Perspectiva, 2014.

CARVALHO, I. C. M. Educação Ambiental Crítica: nomes e endereçamentos da educação. In Layrargues, P. P. (coord.). Identidades da educação ambiental brasileira. Brasília. MMA, 2004.

CARVALHO, I. C. M. Qual educação ambiental? Elementos para um debate sobre educação ambiental e extensão rural. Agroecol.e Desenv. Rur. Sustent., Porto Alegre, v.2, n.2, 2001.

CASTELLS, M. O poder da identidade. São Paulo: Paz e Terra, 1999.

CONAMA. Resolução CONAMA $n^{\circ}$ 292, de 21 de março de 2002. Disciplina o cadastramento e recadastramento de Entidades Ambientalistas no CNEA. Diário Oficial da União, DF, 8 mai. 2002, seção 1, p. 300-331.

COSTA, A. A.; TAGLIANI, P. R. A. Transição para a sustentabilidade na Pesca de Pequena Escala no Extremo Sul do Brasil. In: III Encontro da ANPPAS, Brasília-DF, 2006. Anais eletrônicos... $\quad$ Brasília-DF, $2006 . \quad$ Disponível em: <www.anppas.org.br/encontro_anual/encontro3/arquivos/TA630-11032006211123.DOC $+\& \mathrm{~cd}=1 \& \mathrm{hl}=$ pt-BR\&ct=clnk\&gl=br> Acesso em: 12 jun. 2015. 
CRESWELL, J. W. Investigação qualitativa e projeto de pesquisa: escolhendo entre cinco abordagens. $3^{\mathrm{a}}$ ed. Porto Alegre: Penso, 2014.

CZAPSKI, S. Os diferentes matizes da educação ambiental no Brasil: 1997-2007. 2a ed. Brasília, DF: MMA, 2009.

DIAS, G. F. Educação Ambiental: princípios e práticas. 9ª ed. São Paulo: Gaia, 2004.

DI BENEDITTO, A. P. M. et al. Plano de ação nacional para a conservação do pequeno cetáceo Toninha: Pontoporia blainvillei. Brasília: Instituto Chico Mendes de Conservação da Biodiversidade, ICMBio, 2010.

DIEGUES, A. C. S. Desenvolvimento sustentável ou sociedades sustentáveis: da crítica dos modelos aos novos paradigmas. São Paulo em Perspectiva, São Paulo, v. 6, n. 1-2, p. 22-29, jan./jun. 1992.

DIEGUES, A. C. O mito moderno da natureza intocada. $3^{\text {a }}$ ed. São Paulo: Hucitec. 2001.

DIEGUES, A. C. O papel das grandes ongs transnacionais e da ciência na conservação da natureza. NUPAUB. São Paulo, 2008.

DIEGUES, A. C. (Org.). Os saberes tradicionais e a biodiversidade no Brasil. São Paulo: MMA/COBIO/NUPAUB/USP, 2000.

DIEGUES, A. C. Pescadores, camponeses e trabalhadores do mar. São Paulo: Ed. Ática, 1983.

DIEGUES, A. C. S. Povos e Mares: Leituras em sócio-antropologia marítima. São Paulo: NUPAUB-USP, 1995.

DITTY e REZENDE. Participação pública, pescadores artesanais e a implantação de um megaprojeto costeiro. Soc. nat., Uberlândia, v. 25, n. 1, 2013. Disponível em: <http://www.scielo.br/scielo.php?script=sci_arttext\&pid=S1982-

45132013000100005\&lang=pt> Acesso em: 20 abr. 2015.

FERREIRA, L. C. Conflitos sociais contemporâneos: considerações sobre o ambientalismo brasileiro. Ambiente \& Sociedade, v. 2, n. 5, 1999. 
FERREIRA, R. H. P. C. Diálogo escola-comunidade: reflexões sobre saberes e formação de professores. Dissertação (Mestrado em Educação) - Universidade Estadual Paulista, 2005.

FERREIRA, S. O. Tutoria para uma aprendizagem dialógica e colaborativa: um estudo de caso. Dissertação (Mestrado em Educação) - Universidade do Estado de Santa Catarina, 2011.

FIGUEIREDO, E. M. Educação ambiental na percepção de uma comunidade de pescadores artesanais na costa paraense. Ambiente \& Educação, Rio Grande, v. 16, n. 1, 2011. Disponível em: < http://www.seer.furg.br/ambeduc/article/view/1687> Acesso em: 22 mai. 2015.

FIGUEIREDO, J. B. A. As contribuições de Paulo Freire para uma educação ambiental dialógica. Anped, 29 ${ }^{\mathrm{a}}$ RA. GT Educação ambiental, 2006. Disponível em: <http://arquivos.ambiente.sp.gov.br/cea/cea/GT22_2184.pdf> Acesso em: 12 fev. 2018.

FIGUEIREDO, J. B. A. Educação Ambiental Dialógica e Representações Sociais da Água em Cultura Sertaneja Nordestina: Uma contribuição à consciência ambiental em Irauçuba CE (Brasil). Tese (Doutorado em Ecologia e Recursos Naturais) - Universidade Federal de São Carlos, 2003.

FONTANELLA, B. J. B.; RICAS, J.; TURATO, E. R. Amostragem por saturação em pesquisas qualitativas em saúde: contribuições teóricas. Cad. Saúde Pública, Rio de Janeiro, n. 24, v. 1, 2008.

FOOD AND AGRICULTURE ORGANIZATION OF THE UNITED NATIONS. Code of Conduct for Responsible Fisheries. Rome: FAO, 1995.

1999

Indicators for sustainable development of marine capture fisheries. Rome: FAO,

Voluntary Guideliness for Securing Sustainable Small-Scale Fisheries in the Context of Food Securityand Poverty Eradiction. Roma: FAO, 2015.

. What is the Code of Conduct for Responsible Fisheries? Rome: FAO, 2001 
FÓRUM GLOBAL DAS ONGs. Tratado de Educação Ambiental para Sociedades Sustentáveis e Responsabilidade Global. Rio de Janeiro: 1992. Disponível em: <http://portal.mec.gov.br/secad/arquivos/pdf/educacaoambiental/ tratado.pdf >. Acesso em: 25 mar. 2014.

FOSSALUZA, A. S. As ações em Educação Ambiental realizadas por Organizações NãoGovernamentais no Estado de São Paulo: alcances e limitações. Dissertação (Mestrado em Educação para a Ciência). Universidade Estadual Paulista Júlio de Mesquita, Bauru, 2015.

FREIRE, P. À sombra desta mangueira. 11 a ed. Rio de Janeiro: Paz e Terra, 2013.

FREIRE, P. Extensão ou comunicação? 8ª ed. Rio de Janeiro: Paz e Terra, 1983.

FREIRE, P. Pedagogia da Esperança: Um reencontro com a Pedagogia do Oprimido. Rio de Janeiro: Paz e Terra, 1992.

FREIRE, P. Pedagogia do Oprimido. 10ª ed. Rio de Janeiro: Paz e Terra, 1981.

FREIRE, P.; SHOR, I. Medo e Ousadia: O cotidiano do professor. Rio de Janeiro: Paz e Terra, 1986.

GABASSA, V. Comunidades de aprendizagem: a construção da dialogicidade na sala de aula. Tese (Doutorado em Educação) - Universidade Federal de São Carlos, 2009.

GARCIA, N. M. et al. Educando meninos e meninas: transmissão geracional da pesca artesanal no ambiente familiar. Psic. da Ed., São Paulo, n. 25, 2007. Disponível em: < repositorio.furg.br/bitstream/handle/1/1557/Educando $\% 2520$ meninos $\% 2520 \mathrm{e} \% 2520$ meninas.. .pdf\%3Fsequence\%3D1+\&cd=1\&hl=pt-BR\&ct=clnk\&gl=br> Acesso em: 23 abr. 2015.

GOHN, M. G. Ações coletivas civis na atualidade: dos programas de responsabilidade/compromisso social às redes de movimentos sociais. Ciências Sociais Unisinos, São Leopoldo, v. 46, n. 1, p. 10-17, 2010.

GOHN, M. G. Sociedade Civil no Brasil: movimentos sociais e ONGs. Meta: Avaliação, Rio de Janeiro, v. 5, n. 14, p. 238-253, 2013. 
IARED, V. G. et al. Coexistência de diferentes tendências em análises de concepções de educação ambiental. Rev. eletrônica Mestr. Educ. Ambient., v. 27, p. 14-29, julho a dezembro de 2011.

INSTITUTO BIOPESCA. Pescador Amigo. Projeto aprovado no edital Petrobras Ambiental, 2012.

. Relatório Final - Evidências de matriz lógica [Projeto Pescador Amigo], 2015e.

Relatório I - Evidência de educação ambiental [Projeto Pescador Amigo], 2013.

2014a.

Relatório II - Evidência de matriz lógica - Item 3.1 [Projeto Pescador Amigo], $2014 b$.

Relatório II - Evidência de matriz lógica - Item 4.1 [Projeto Pescador Amigo, 2014h.

Relatório III - Evidência de matriz lógica - Item 2.4 [Projeto Pescador Amigo], $2014 f$.

Relatório III - Evidência de matriz lógica - Item 3.2 [Projeto Pescador Amigo], 2014c.

Relatório III - Evidência de matriz lógica - Item 4.2 [Projeto Pescador Amigo], $2014 \mathrm{e}$.

Relatório III - Evidência de matriz lógica - Item 4.3 [Projeto Pescador Amigo], 2014 i.

Relatório IV - Evidência de matriz lógica - Item 2.4 [Projeto Pescador Amigo], $2014 \mathrm{~g}$.

Relatório IV - Evidência de matriz lógica - Item 3.2 [Projeto Pescador Amigo], 
INSTITUTO BIOPESCA. Relatório IV - Evidência de matriz lógica - Item 4.2 [Projeto Pescador Amigo], 2014d.

$2015 f$.

Relatório V - Evidência de matriz lógica - Item 2.4 [Projeto Pescador Amigo], $2014 \mathrm{j}$.

Relatório V - Evidência de matriz lógica - Item 3.2 [Projeto Pescador Amigo], $2015 b$.

Relatório V - Evidência de matriz lógica - Item 5.1 [Projeto Pescador Amigo], $2015 \mathrm{a}$.

Relatório VI - Evidência de matriz lógica - Item 3.2 [Projeto Pescador Amigo], $2015 \mathrm{~g}$

Relatório VI - Evidência de matriz lógica - Item 4.3 [Projeto Pescador Amigo], $2015 c$.

Relatório VI - Evidência de matriz lógica - Item 5.2 [Projeto Pescador Amigo], $2015 \mathrm{~d}$.

Relatório VI - Evidência de matriz lógica - Item 5.3 [Projeto Pescador Amigo],

INSTITUTO ECOAR PARA A CIDADANIA. Manual de metodologias participativas para o desenvolvimento comunitário. São Paulo: ECOAR, 2008.

ISAACS, W. Accessing genuine dialogue. The watercooler, v. 6, n. 4, 2012.

ISAACS, W. Dialogue and the art of thinking together: a pioneering approach to communicating in business and in life. New York: Doubleday, 1999.

ISAACS, W. Taking Flight: Dialogue, Collective Thinking, and Organizational Learning. Organizational Dynamics v. 22, n. 2, p. 24-39, 1993. 
JACOBI, P. Meio Ambiente e redes sociais: dimensões intersetoriais e complexidade na articulação de práticas coletivas. Revista de Administração Pública. Rio de Janeiro v. 34, n. 6, p. 131-58, 2000.

LANDIM, L. Experiência militante: Histórias das assim chamadas ONGs. Lusotopie 2002. Disponível em: < www.lusotopie.sciencespobordeaux.fr/landim.rtf> Acesso em: 9 mar. 2018.

LAYRARGUES, P.P. (coord.). Identidades da educação ambiental brasileira. Brasília: MMA, Diretoria de Educação Ambiental, 2004.

LAYRARGUES, P. P.; LIMA, G. F. C. As macrotendências político-pedagógicas da educação ambiental brasileira. Ambient. soc., São Paulo, v. 17, n. 1, 2014. Disponível em: $<$ http://www.scielo.br/scielo.php?pid=S1414753X2014000100003\&script=sci_abstract\&t $\operatorname{lng}=\mathrm{pt}>$ Acesso em: 15 jan. 2018.

LEAL, G. F. Justiça ambiental, conflitos latentes e externalizados: estudo de caso de pescadores artesanais do norte fluminense. Ambient. soc., São Paulo, v. 16, n. 4, 2013. Disponível em: <http://www.scielo.br/scielo.php?script=sci_arttext\&pid=S1414753X2013000400006\&lng=en\&nrm=iso>. Acesso em: 15 mai. 2015.

LIMA, D. M. A. Educação ambiental dialógica e descolonialidade com crianças indígenas Tremembé: vinculação afetiva pessoa-ambiente na escola Maria Venância. Tese (Doutorado em Educação Brasileira) -Universidade Federal do Ceará, 2014.

LOGAREZZI, A. J. M. Educação ambiental em comunidades de aprendizagem: uma abordagem crítico-dialógica. In: REUNIÃO ANUAL DA ANPED, 33, 2010, Caxambu. Anais eletrônicos... Rio de Janeiro: Anped, 2010. CD-ROM.

LUCA, A. Q.; ANDRADE, D. F. O 'diálogo' como objeto de pesquisa na educação ambiental. In: GUNTZEL-RISSATO, C. et al. (Org.) Educação ambiental e políticas públicas: conceitos, fundamentos e vivências. Curitiba: Appris, 2013.

LUDKE, M; ANDRÉ, M. E. D. A. Pesquisa em Educação: Abordagens Qualitativas. São Paulo: EPU, 1986.

MACHADO, A. M. B. O percurso histórico das ongs no Brasil: perspectivas e desafios no campo da educação popular. In: IX SEMINÁRIO NACIONAL DE ESTUDOS E PESQUISAS “HISTÓRIA, SOCIEDADE E EDUCAÇÃO NO BRASIL”, 2012, João Pessoa. Anais eletrônicos... João Pessoa: Universidade Federal da Paraíba, 2012. 
MARCONI, M. A.; LAKATOS, E. V. Fundamentos de metodologia científica. $5^{\text {a }}$ ed. São Paulo: Atlas, 2003.

MARRUL-FILHO, S. Crise e Sustentabilidade no uso dos recursos pesqueiros. Dissertação (Mestrado em Desenvolvimento Sustentável) - Universidade de Brasília 2001.

MCCORMICK, J. Rumo ao Paraíso: A História do Movimento Ambientalista. Rio de Janeiro: Relume-Dumará, 1992.

MINAYO, M. C. S. Ciência, técnica e arte: o desafio da pesquisa social. In: MINAYO, M. C. S. (org). Pesquisa Social: teoria, método e criatividade. 21 ${ }^{\mathrm{a}}$ ed. Petrópolis: Vozes, 2002.

MINISTÉRIO DA INSDÚSTRIA, COMÉRCIO EXTERIOR E SERVIÇOS. Institucional. Disponível em: < http://www.mdic.gov.br/institucional> Acesso em: 02 de abr. 2017.

MINISTÉRIO DO MEIO AMBIENTE. A Convenção sobre Diversidade Biológica - CDB. Brasília: MMA, 2000. Disponível em: http://www.mma.gov.br/estruturas/sbf_chm_rbbio/_arquivos/cdbport_72.pdf> Acesso em: 20 set. 2017.

NAVARRO, A. Diálogos e reflexão. Tese (Doutorado em Educação) - Universidade Federal do Rio Grande do Norte, 2005.

NETO, J. D. Pesca no Brasil e seus aspectos institucionais - um registro para o futuro. Revista CEPSUL - Biodiversidade e Conservação Marinha, Itajaí, SC, v. 1, n. 1, 2010. Disponível em: <http://www.icmbio.gov.br/revistaeletronica/index.php/cepsul/article/view/300/250> Acesso em: 4 mar. 2015.

NICOLESCU, B. O Manifesto da Transdisciplinaridade. São Paulo: Triom, 1999.

OCA. O "Método Oca" de Educação Ambiental: fundamentos e estrutura incremental. AMBIENTE \& EDUCAÇÃO, v. 21, n. 1, p. 75-93, 2016.

OLIVEIRA, A. C.; HADDAD, S. As organizações da sociedade civil e as ongs de educação. Cadernos de Pesquisa, $n^{\circ} 112$, p. 61-83, 2001. 
OLIVEIRA, M. W. Processos educativos em trabalhos desenvolvidos entre comunidades: perspectivas de diálogo entre saberes e sujeitos. Pesquisa componente do Pós-doutorado, 2003. Disponível em: $<$ http://www.processoseducativos.ufscar.br/relatorio1.pdf $>$ Acesso em: 4 nov. 2016.

ÓRGÃO GESTOR DA PNEA. ProNEA: Educação Ambiental - Por um Brasil Sustentável. $4^{\mathrm{a}}$ ed - Brasília: Ministério do Meio Ambiente, 2014.

ÓRGÃO GESTOR DA PNEA. Programa nacional de formação de educadoras(es) ambientais: por um Brasil educado e educando ambientalmente para a sustentabilidade. Série Documentos técnicos 7, Brasília: Órgão Gestor da Política Nacional de Educação Ambiental, 2006.

PEREIRA, M. O. R. Educação ambiental com pescadores artesanais: um convite à participação. Práxis Educativa, Ponta Grossa, PR, v. 3, n. 1, 2008. Disponível em: <www.revistas2.uepg.br/index.php/praxiseducativa/article/.../344/352> Acesso em: 16 mar. 2015 .

PERUCCHI, L.C.; KUBO, R. R.; COELHO-DE-SOUZA, G. Articulação e encaminhamento das questões da pesca artesanal. Revista da Gestão Costeira Integrada, v. 12, n. 4, 2012. Disponível em: <http://www.lume.ufrgs.br/handle/10183/108893> Acesso em: 14 jun. 2015.

PETROBRAS. Programa Petrobras Ambiental: Regulamento Seleção Pública 2012. Disponível em: $<$ http://sites.petrobras.com.br/socioambiental/files/pdf/2012_Programa\%20Petrobras\%20Am biental_Regulamento.pdf> Acesso em: 13 mai. 2017

ROESE, M. W. V. Educação ambiental dialógico-crítica e a conservação da biodiversidade no entorno de áreas protegidas. Tese (Doutorado em Ecologia e Recursos Naturais) - Universidade Federal de São Carlos, 2014.

SAUVÉ, L. Cartografia da Educação Ambiental In: SATO, M. e CARVALHO, I.C.M. (Org.) Educação Ambiental - pesquisa e desafios. 1. ed. Porto Alegre: Artmed, 2005.

SILVA, L. P. Conflitos socioambientais: uma proposta de investigação-ação à luz da educação ambiental dialógico-problematizadora. Tese (Doutorado em Ciências Ambientais) Universidade Federal de Goiás, 2016. 
SORRENTINO, M. Educador Ambiental Popular. In: FERRARO JUNIOR, L. A. (Org.). Encontros e Caminhos: Formação de Educadoras(es) Ambientais e Coletivos Educadores Volume 3. Brasília: MMA/DEA, 2014.

SORRENTINO, M. Educação Ambiental e Políticas Públicas. In: ENCONTRO PANAMAZÔNICO DE EDUCAÇÃO AMBIENTAL. Belém do Pará. Palestras...Belém do Pará, 2005.

SORRENTINO, M. Educação Ambiental e Universidade: um estudo de caso. Tese (Doutorado em Educação) - Universidade de São Paulo, 1995.

SORRENTINO, M. et al. Comunidade, identidade, diálogo, potência de ação e felicidade: fundamentos para educação ambiental. In: GUNTZEL-RISSATO, C. et al. (Org.) Educação ambiental e políticas públicas: conceitos, fundamentos e vivências. Curitiba: Appris, 2013, p. $36-41$.

SOUSA, E. R. M. et al. Avaliação da percepção ambiental da comunidade ribeirinha Vila Rio no município de Conceição do Araguaia-PA. In: III Congresso Brasileiro de Gestão Ambiental, Goiânia, 2012. Anais eletrônicos... Goiânia, 2012. Disponível em: <www.ibeas.org.br/congresso/Trabalhos2012/VIII-002.pdf> Acesso em: 18 jan. 2015.

SOUZA, A. G. C. Educação ambiental como política social: estratégia de reação social a pesca predatória no município de Pracuúba-AP. Dissertação (Mestrado em Direito Ambiental e Políticas Públicas) - Universidade Federal do Amapá, 2012.

SOUZA, S. C. Educação ambiental dialógico-crítica no Pantanal de Mato Grosso: a voz e o silêncio das pescadoras e dos pescadores tradicionais. Tese (Doutorado em Ciências Ambientais) - Universidade Federal de São Carlos, 2017.

STEIL, C. A.; CARVALHO, I. C. M. ONGs: itinerários políticos e identitários. Cultura y Neoliberalismo. Buenos Aires, 2007. Disponível em: <http://bibliotecavirtual.clacso.org.ar/clacso/gt/20100919080712/11Steil-Carvalho.pdf> Acesso em: 25 jan. 2018.

STEWART, J.; ZEDIKER, K. E.; BLACK, L. Relationships among philosophies of dialogue. In: ANDRESON, R.; BAXTER, L. A.; CISSNA, K. N (Ed.). Dialogue: theorizing difference in communication studies. Thousand Oaks: Sage, 2004.

SUASSUNA, D. A educação ambiental e o Projeto Tamar. Ambiente e Educação, Rio Grande, n. 9, p. 55-67, 2004. 
TRISTÃO, V. T. V. Educação Ambiental Não Formal: a experiência das organizações do terceiro setor. Tese (Doutorado em Educação) - Universidade de São Paulo, 2011.

XAVIER, R. B.; SZYMANSKI, H. Compreensão do diálogo em um processo de construção coletiva do projeto político-pedagógico. Rev. bras. Estud. pedagog. (online), Brasília, v. 96, n. 242, p. 61-78, 2015. 